Portland State University

PDXScholar

1989

\title{
Bone Tool Assemblages as an Aid to Shell Mound Site Typologies on the Northwest Coast
}

Doria Lee Fingerhut Raetz

Portland State University

Follow this and additional works at: https://pdxscholar.library.pdx.edu/open_access_etds

Part of the Archaeological Anthropology Commons Let us know how access to this document benefits you.

\section{Recommended Citation}

Fingerhut Raetz, Doria Lee, "Bone Tool Assemblages as an Aid to Shell Mound Site Typologies on the Northwest Coast" (1989). Dissertations and Theses. Paper 3929.

https://doi.org/10.15760/etd.5813

This Thesis is brought to you for free and open access. It has been accepted for inclusion in Dissertations and Theses by an authorized administrator of PDXScholar. Please contact us if we can make this document more accessible: pdxscholar@pdx.edu. 
AN ABSTRACT OF THE THESIS OF Doria Lee Fingerhut Raetz for the Masters of Arts in Anthropology presented

Title: Bone Tool Assemblages as an Aid to Shell Mound Site Typologies on the Northwest Coast

APPROVED BY THE MEMBERS OF THE THESIS COMMITTEE:

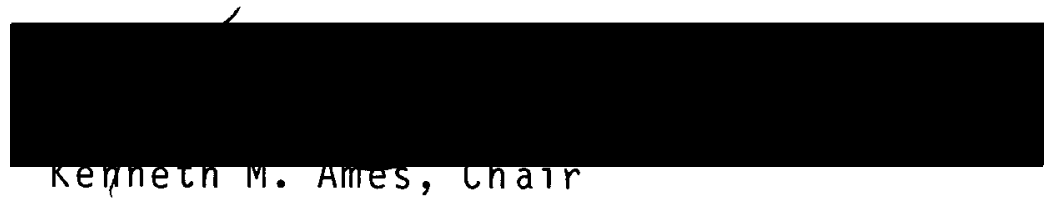

Kepmeon 1 i. Ames, chatr

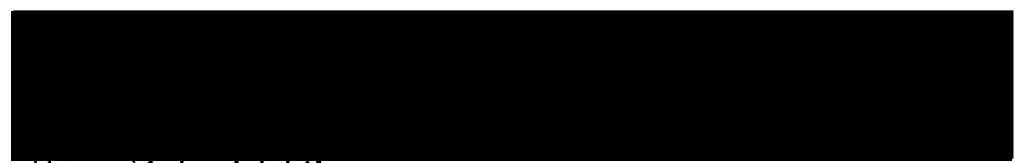

wayne sutters
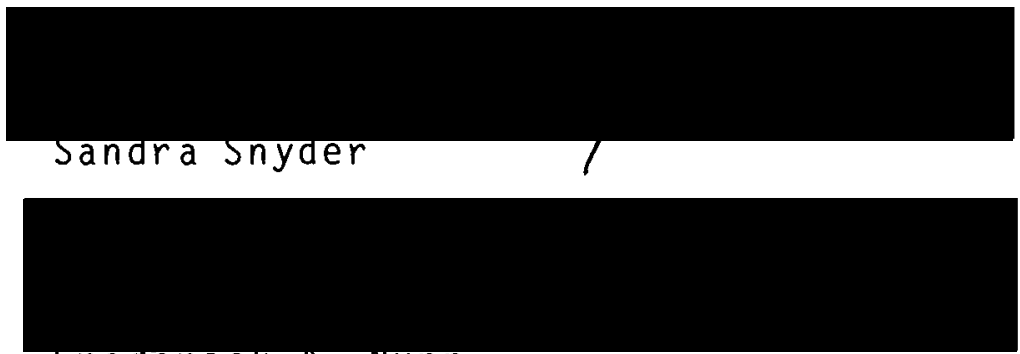

FrederTCk A. Nunn

Fifteen bone tool assemblages from shell midden sites were compared. Three of these are unpublished sites from Prince Rupert Harbor. They were grouped using cluster analysis. Inter and intragroup variation in bone tool assemblage structure was analyzed. One of the objectives of this study was to generate hypotheses about the function of 
the unpublished sites by comparing their bone tool

assemblages with those from sites which are better understood by looking for underlying patterns in the bone tool

assemblages. Other objectives were to test the utility of using bone tool assemblages as a diagnostic tool in analyzing sites and to test the utility of the cluster analysis procedure with this data set.

Hypotheses were developed identifying possible site usage at the three Prince Rupert Harbor sites, Boardwalk (GbTo-31), Garden Is 1 and (GbTo-23), and Grassy Bay (GbTn-1). Bone tool assemblages were shown to be a useful aid in site analysis and cluster analysis was quite useful in identifying existing patterns in these data. 
BONE TOOL ASSEMBLAgES AS AN AID TO SHELL MOUND SITE TYPOLOGIES ON THE NORTHWEST COAST

\author{
by
}

DORIA LEE FINGERHUT RAETZ

\begin{abstract}
A thesis submitted in partial fulfillment of the requirements for the degree of
\end{abstract}

\author{
MASTER OF ARTS \\ in \\ ANTHROPOLOGY
}

Portland State University

1989 
TO THE OFFICE OF GRADUATE STUDIES:

The members of the Committee approve the thesis of Doria

Lee Fingerhut Raetz presented

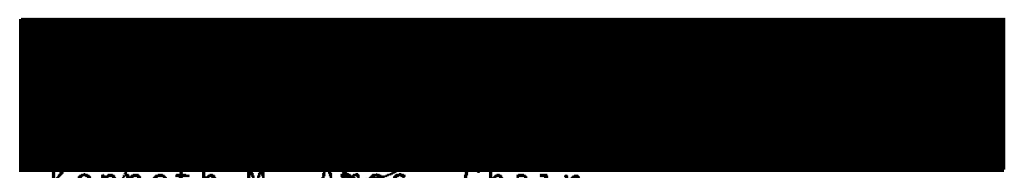

Kemeth M. Alites, chair

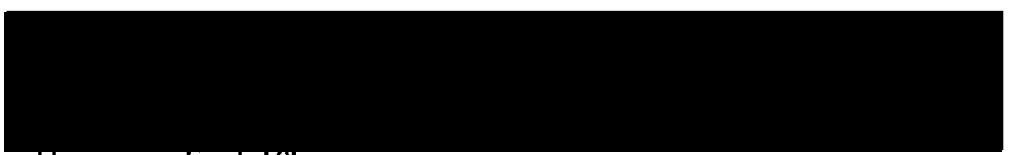

wayne suttyes
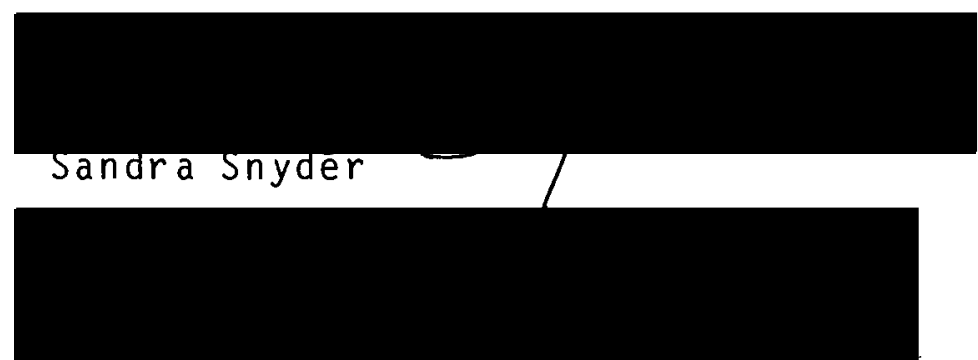

Frederick A. Nunn

APPROVED :

Marc S. Feldesman, Chair, Department of Anthropology

C. willam savery, Interyil vice Provost for Graduate stuates and Research 


\section{ACKNOWLEDGEMENTS}

The research and writing of this thesis drew on the talents, time, experience and compassion of many people. My thesis committee chair, Dr. Kenneth M. Ames, provided invaluable aid. He made his personal library and computer available to me, hired me as a research assistant, prodded me when I needed prodding and gave me much personal support through the stresses and strains of completing a Master's degree. In short, he has been a true teacher and mentor for me. Dr. M. Ann Bennett also helped me tremendously with the computer programming necessary in the early stages of the research. Using her expertise as both teacher and programmer, she taught me much about the organization of data and about "talking" to computers.

The members of my thesis committee, Dr. Wayne Suttles, Dr. Fred Nunn and Dr. Sandra Snyder took the time to give detailed and very thoughtful comments on the drafts of the thesis. I truly appreciate their efforts and consideration.

The basic research for this thesis was done as part of the Prince Rupert Harbor Artifact Analysis Project. This project has been funded by the National Science Foundation, and made possible by the loan of materials from the National Museum of Canada. 
The logistics of completing the research and writing the thesis after the birth of our child required the help of several other people, equally necessary to the completion of this project. My mother, Neill Fingerhut, provided love and childcare above and beyond the call of grandmotherhood. I credit the maintanance of sanity in this household to her presence at critical times. Thanks, Mom!

My daughter's other childcare providers were Bonnie McAnnis-Entenmann and Julie Chasteen, two wonderful teachers and caring people. Helen Raetz and my dear friend Beth Murphy also provided wonderful care for my child. My husband, Rick, saw to it that some semblance of a normal 1 ife prevailed during the days which turned into years of graduate school. 
TABLE OF CONTENTS

PAGE

ACKNOWLEDGEMENTS . . . . . . . . . . . .

LIST OF TABLES ................. . . vii

LIST OF FIGURES ..................... vii

CHAPTER

I INTRODUCTION......... .11

The Setting . . . . . . 3

Prehistory of the Northwest Coast . 6

Ethnographic Information •. • 9

I I SITE DESCRIPTIONS . . . . . . . 14

Boardwalk (GbTo 31) . . . . . 14

Garden Is land (GbTo 23) . . . 19

Grassy Bay (GbTn 1) . . . . 21

Yakutat Bay ("01d Town") .... 23

Grant Anchorage (FcTe 4) •. . 26

0'Connor (EeSu 5) ....... 29

Belcarra Park (DhRr 6) . . . . 31

Duke Point (DgRx $5,11,29,36) . .34$

Georgeson Bay (DfRu 24) • . • • 37

Montague Harbor (DfRu 13) . . . 40

Little Qualicum River (DiSc 1) . . 43

Hesquiat (DiSo 1) . . . . . 4 46

Shoemaker Bay (DhSe 2) . . . . 49 
Cattle Point (SJ1) . . . . . 53

Skwikwikwab (45SK33A, 45SK33B, 45 SK99) ........ 57

I I METHODS . . . . . . . . . . . 61

Descriptions of the Tool Types . 65

Cluster Analysis...... 75

IV ANALYSIS ............... 80

V CONCLUSIONS..................... 105

REFERENCES . . . . . . . . . . . . 111

APPENDIX . . . . . . . . . . . . . . 119 


\section{LIST OF TABLES}

TABLE

PAGE

I Sources of Artifact Inventories used

to Create Revised Typologies ....

I I Raw Data Organized into Combined Class

Clusters (figures in parentheses are percent of total) . . . . . .

I I Raw Data Organized into Individual Tool

Class Clusters - Cluster 1a (figures

in parentheses are percent of total).

IV Raw Data Organized into Individual Tool

Class Clusters - Cluster 1b (figures

in parentheses are percent of total).

$\checkmark$ Raw Data Organized into Individual Tool

Class Clusters - Cluster 1c (figures

in parentheses are percent of total).

VI Raw Data Organized into Individual Tool

Class Clusters - Cluster 2 a (figures

in parentheses are percent of total).

VII Raw Data Organized into Individual Tool

Class Clusters - Cluster 2b (figures

in parentheses are percent of total). 


\section{LIST OF FIGURES}

F IGURE

PAGE

1. Map of Northern and Central Northwest Coast 4

2. Excavated Sites in the Prince Rupert Area . 16

3. Boardwalk Site, GbTo 31 ....... 17

4. Garden Is land Site, GbTo 23 ..... 20

5. Grassy Bay Site, GbTn 1 . . . . . 22

6. "01d Town" Site, Yakutat Bay ...... 24

7. The Hecate Strait - Milbanke Sound area.. 27

8. Grant Anchorage site, FcTe 4 ..... 28

9. 0'Connor site, EeSu 5 ....... 30

10. Strait of Georgia area ........ 32

11. Area of Belcarra Park site, DhRr 6 ... 33

12. Duke Point sites, DgRx 5, 11, 29, 36 . . 35

13. Georgeson Bay site, DfRu 24 . . . . 38

14. Montague Harbor site, DfRu 13 . . . . 41

15. Location of Little Qualicum River site,

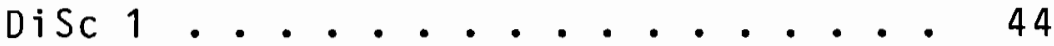

16. Hesquiat site, DiSo 1 ........ 47

17. Recorded archeological sites in the Alberni Valley............. 50

18. Shoemaker Bay site, DhSe 2 ...... 51

19. Cattle Point site, Su1 ........ 54

20. Skwikwikwab sites, 45SK33A, 45SK33B, 45SK99 58 
21. North Fork Skagit River archeological sites 59

22. A. Composite fish hook B. 3-part harpoon

assembly C. Methods of line attachment to harpoon head . . . . . . . . . 66

23. Toggling harpoon assembly . . . . . . 69

24. Combined class cluster analysis dendrogram 81

25. Individual tool type cluster analysis 


\section{CHAPTER I}

\section{INTRODUCT ION}

This study has three purposes. The first is to generate hypotheses which tentatively identify the subsistence functions of three shel1 midden sites in Prince Rupert Harbor. These hypotheses will be tested in a later study. The second purpose is to assess the usefulness of bone tool assemblages in identifying some of the subsistence activities practiced at shell mound sites. The third purpose is to test the utility of cluster analysis in analyzing these data.

The three unpublished shell midden sites, Boardwalk (GbTo 31), Garden Is 1 and (GbTo 23), and Grassy Bay (GbTn 1) were excavated as part of the North Coast Prehistory Project under the general direction of George F. MacDonald. The excavations and other activities were carried out between 1967 and 1973. The Prince Rupert Harbor Artifact Analysis Project was then initiated in 1983 under the direction of Kenneth M. Ames, with the goal of analyzing the artifacts from the twelve Prince Rupert Harbor shell midden sites. The amount of data to be analyzed from Prince Rupert Harbor is staggering. The number of artifacts from these twelve sites total more than 18,000. As a small part of this analysis, I undertook to compare the bone tool assemblages 
from three of these sites and to develop hypotheses identifying the possible subsistence function of the sites. This would be done by searching for underlying regularities in the bone tool assemblages. Regular patterns in the bone tool assemblages may be related to some of the subsistence activities practiced at the sites. GbTo 31 , GbTo 23 and GbTn 1 were selected because these are the sites about which most was known. Some preliminary research on these sites had been done by other people (Ames 1974, F. Stewart 1977).

These unpublished sites needed a context for comparison. I chose twelve other coastal shell midden sites from along the Northwest Coast. These sites were relatively well-known, and the literature provided descriptions of the artifacts that were detailed enough to allow comparisons. Bone tools make up the largest portion of the Prince Rupert Harbor site inventories, so I decided to limit the analysis to bone tools only.

The most common method of analyzing bone tools on the Northwest Coast has been to compare sites for the presence or absence of unusual tool types. Comparison of the presence or absence of certain harpoon head types is a favored approach. It is not usually the practice to closely examine the bone tool assemblage as a unit, however. The present study searches for patterns in the bone tool assemblages as clues to site function. 
THE SETTING

The Northwest Coast extends from the mouth of the Copper River in Alaska to Trinidad Bay in California (Drucker 1955, p. 1). It lies west of the coastal mountain ranges which run roughly parallel to the shore along the west coast of North America. It is bounded on the west by the Pacific ocean. The area includes many islands, large and small, which protect the coastline and inner waterways from the full force of the North Pacific winter storms. The sites used in this study are found in the northern and central portions of the Northwest Coast, from Puget Sound north to the Copper River (see Figure 1). Detailed descriptions of the geology and the resources of the Northwest Coast can be found elsewhere (such as Putnam 1952; Heusser 1960; Guberlet 1956; Quayle 1960; Turner 1975; Cowan and Guiguet 1965). What follows is a greatly simplified overview of the setting and resources to be found in the northern and central sections of the Northwest Coast. Only data relevant to the analysis which follows will be presented here.

The Northwest Coast is known for its cool, wet climate. The steep Coast Mountains rise rapidly from the coast. The relatively warm, moist a ir comes in from the sea on the prevailing southwesterly winds. The rapid rise up the mountainsides causes the moisture to condense and fall on the 


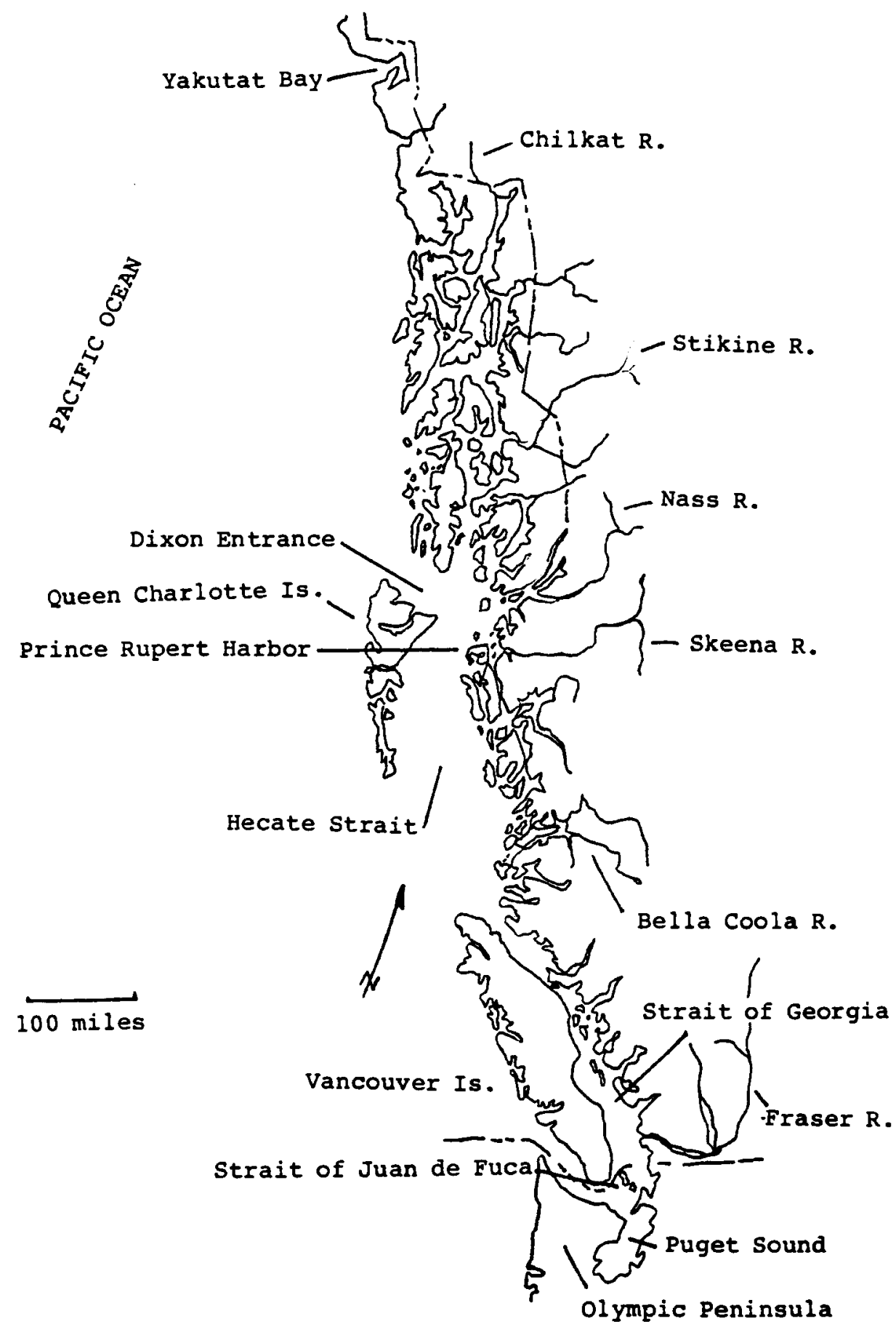

Figure 1. Map of Northern and Central Northwest Coast. 
coast. Cold dry air then continues on to the interior plateaux (Putnam 1952).

Deep, narrow fjords exist where the steep, glacier-cut mountains reach the sea (Heusser 1960). This greatly lengthens the effective coastline. This long and jagged coast is lined with very productive littoral zones, rich in shellfish, seaweed, waterfowl, and fish (Guberlet 1956, Quayle 1960).

Large amounts of rainfall run down the steep mountains to form a myriad of streams and some large river systems. These are host to the vast salmon (Onchorhynchus spp.) spawning runs from spring through the late fall. Eulachon (Thaleichthys pacificus) also spawn in some of the rivers of the Northwest.

Important floral resources included red cedar, hemlock, and spruce, with their useful outer and inner bark. Hemlock and spruce also have an edible and nutritious cambium. The edge of the forest, the forest understory, and meadows contained a variety of edible berries, wild roses, ferns, and a few tubers. Mosses and skunk cabbage were also used in daily life (Turner 1975).

The forests come right down to the coast. Shell mound sites are found at the interface between the littoral and forest zones. Animals, as well as plants, were sought from the forest. Deer and elk, where available, were the most important but beaver, porcupine, and other smaller animals 
were trapped as we11. Black bear and mountain goats were hunted whenever possible (Cowan and Guiguet 1965).

The inner waterways along the coast were home to many food species, including harbor seals, sea otters, and harbor porpoises. Whales were scavenged when they washed ashore and were actively hunted by some groups. Bottomfish, including halibut, are caught on banks where they live in the winter. Winter is also the time when schools of herring come into the kelp beds in shallow waters, waiting to spawn in the spring (Stewart 1975, Scammon 1968, Hoos 1975, Drucker 1965, Niblack 1970).

\section{PREHISTORY OF THE NORTHWEST COAST}

The complex prehistory of the northern and central Northwest Coast will not be recounted here in detail. The reader is referred to many fine syntheses of Northwest regional prehistory (Borden 1970, 1975; Burley 1980; Matson 1980; Carlson 1983a; Fladmark 1974; Fladmark and Ames, n.d.; MacDonald 1983; Mitchell 1971a, 1971b; Hester and Nelson 1978; Hobler 1970; Thompson 1978). Northwest Coast prehistory in all of its regional and temporal diversity can on ly be truly appreciated by a detailed study of the great body of primary literature (including Carlson 1970; Calvert 1970; Matson 1976; Inglis and MacDonald 1979; Archer 1983, 1984; and many more). Here I will present an outline of the 
region's prehistory. It is drawn largely from Carlson (1983a).

Carlson (1983a) divides Northwest Coast prehistory into three periods; Early $(12,000$ - 5,500 B.P.), Middle (5,500 1,500 B.P.), and Late $(1,500$ B.P. - contact). Initial settlement of the region occurred sometime during the Early Period. The earliest C14 dates range between 8,000 - 10,000 B.P.

There are two different tool complexes represented in the Early Period. North of Queen Charlotte Sound a welldeveloped microblade tradition existed. The Pebble Tool Tradition was to be found south of Queen Charlotte Sound. This tool complex consisted mainly of large chipped stone bifaces and pebble choppers and was largely terrestrial and riverine in focus. By the end of the Early Period the two complexes had blended.

The Middle Period $(5,500-1,500$ B.P. ) saw great changes. The dramatic increase in salmon productivity (see Fladmark 1977) shifted attention away from terrestrial resources, to riverine, littoral, and pelagic resources. From 5,500 B.P. to about 3,500 B.P., human population numbers rose. Large numbers of shell mounds appear at this time, indicating an increased dependence on shellfish.

Population growth was accompanied by the development of wealth, specialization of labor, and permanent or semipermanent plankhouse structures. We also see evidence of 
increasingly extensive use of bone and antler as tool material. Ceremonialism, wealth, and status indicators appear and increase during the Middle Period all along the coast. Art objects, differential burial inclusions, selective skull deformation, and ornaments (such as labrets, beads and pendants) a 11 appear and develop on the Northwest Coast during the Middle Period. Trade networks which were initiated in the Early Period continue, and warfare becomes apparent for the first time in some places. Warfare is indicated by forearm parry fractures, trophy heads (isolated skulls with cut marks on the cervical vertebrae), and mortuary demographics in Prince Rupert Harbor (Cybulski n.d.). The amount and intensity of warfare and the other above-mentioned traits vary by region.

The second half of the Middle Period, from 3,500-1,500 B.P. Saw the emergence of regional patterns recognizably ancestral of the ethnographically known cultures. Population numbers and density continue to grow rapidly. New bone and antler tool types appear at this time, as well.

During the Late Period (1,500 B.P. - contact) patterns established in the second half of the Middle Period were elaborated. Whale-hunting is added to the subsistence strategy on the west coast of Vancouver Island. The evidence from Prince Rupert Harbor indicates that population growth leveled off in the Late Period. Village structures during this period exhibit differences in size, location, faunal 
remains (local or exotic), and quality of those structures (McDonald and Inglis 1980, p. 52).

\section{ETHNOGRAPHIC INFORMATION}

The ethnographic information from the Northwest Coast has been presented in detail elsewhere (Boas, 1909; Barnett 1938, 1955; Niblack 1970; de Laguna 1972; Drucker 1951, 1955, 1965; Suttles 1951, 1968; Oberg 1973; Garfield and Wingert 1950; Mason 1901, 1971; McFeat 1966; Kroeber 1939; and others). I will not present all of that information here, but will present only a few, general facts which are important to the present study.

As stated above, in this study I am generating hypotheses of site usage at three Prince Rupert Harbor shel1 mound sites. The testing of these hypotheses is to be done in the future as part of the Prince Rupert Harbor Artifact Analysis Project. At that time, a detailed study of Prince Rupert Harbor ethnographic information will be needed in order to properly test these hypotheses. I have selected twelve other sites which I will also use in generating these hypotheses. Conclusions regarding subsistence activities at these sites have been offered by many of the authors of the original site reports. I present those conclusions in the Site Descriptions and Analysis chapters of this study, along with some conclusions of my own. These conclusions should also be treated as hypothetical, pending detailed analysis of 
appropriate local and regional ethnographic material, as well as the relevant archeological information not considered here.

Admittedly oversimplifying, a few things may be said about Northwest Coast cultures in general. They used large wooden plank houses, each of which served as the primary winter residence for an extended family. These houses were also used as a base of operations during the rest of the year. Families and other work groups moved in order to fully exploit seasonally available resources (Suttles 1968). Utilization of resources was organized through kinship and status. Usufruct rights (the rights to use certain resources) could be inherited, loaned, rented, or given away.

A11 groups on the Northwest Coast developed ranked social structure, with status achieved, ascribed or a mix of the two (Sapir 1966). All developed artistic and ceremonial aspects. And all followed seasonal rounds which centered on the salmon spawning runs.

Salmon were caught in weirs or traps set out in the rivers (Drucker 1955 pp. 24-26). Dip nets, spears, and harpoons were used to remove the fish from the river or from the traps. The fish were cleaned and dried, and eaten through the winter.

Eulachon was another important food $f i s h$ in the Northwest. These small, oily fish are anadromous. In the early spring they run in the larger rivers including the 
Situk, Nass, Skeena, Kitimat, Bella Coola, Fraser, and kimsquit. These fish were taken with traps and nets and rendered down for their oil. This oil was highly prized and was used as a condiment for everything from dried fish to dried berries. The largest run on the northern coast was on the Nass River. The Tsimshian who controlled access to fishing locations at the mouth of the Nass controlled a very important resource (Drucker 1955 p. 24).

Herring and species of smelt spawn close to shore in late winter or early spring. Herring roe was deposited on seaweed by the fish. People then collected the roe, seaweed and a 11. The eggs and seaweed were separated and dried. The small fish were also caught, using a long piece of wood with fixed pointed bone teeth projecting along one side (Stewart 1977, pp. 41-45). This rake was pulled through the water in a paddling motion, finished by dumping the rakeful of fish into the canoe. Racks holding tree branches were also constructed and floated in the herring schools. These racks were then collected and the roe removed and dried (Drucker $1965, p \cdot 15)$.

Halibut come in close to shore in winter, living on shallow banks (F. Stewart 1975, p. 386). Halibut could be caught on these banks, or in deeper water in spring and early summer when the weather was better (Suttles, personal communication). These, along with rockfishes, cod, and other fish were caught with hook and line. Fish hooks were 
composite, having a wooden shank and armed with a bone point (see Figure 23). Lines were set with one or more baited hooks or baited bipoints (which acted as gorges), or occasionally pulled slowly behind a canoe (Berringer 1982, p. 22 ; Stewart 1977, pp. 41-45; Swan cited in Niblack 1970, p. 291).

Shellfish were abundant on many beaches and some rocky shores. In the north, mollusks were usually collected in the winter, for several reasons. They spawn in the summer and are not generally eaten until the larvae have been released. This may be because the larvae cause a bad flavor (Fladmark 1974, p. 66). Shellfish are also more prone to various poisoning agents during warm weather. However, clams reportedly taste best eaten in their spawning state (quayle $1960, p .12)$. Some Coast Salish groups did most of their shellfish collecting in the summer (Suttles, pers. comm.).

The Northwest Coast is on the flyway of a remarkable variety of migratory waterfowl. Several methods were used in different areas to obtain this resource. Birds were caught by stringing nets across their flight paths in estuaries and marshes. They were also caught with baited bone bipoint gorges (de Laguna $1972, p .373$ ), or struck with blunt arrows or long thin low-barbed multi-pronged spears. Bird were also taken at night, stunned with light and clubbed (Niblack 1970, p. 278). Eggs were collected, as well. Birds were caught for food, but also for their wing and tail feathers and for their 
long hollow leg and wing bones. These hollow bones were made into drinking tubes and whistles.

The berries which ripen in late summer and early fall were collected, crushed, and dried in sheets. These were eaten through the winter dipped in eulachon grease. The cambium of spruce and hemlock were afforded similar treatment, as were the many edible species of seaweed (Turner $1975)$.

In the north, land mammals were usually hunted in the winter when they came down to lower elevations. In the central Northwest Coast and especially on the Gulf Islands, land mammals were available for hunting all year round. Traps, deadfalls, and pitfalls were constructed. Bow and arrow, drives, and dogs were also used in some places.

Sea mammals were also hunted. These animals provided furs, fat to be rendered into oil, bone for raw material, and meat. They formed an important part of the economy in nearly all areas of the northern and central Northwest Coast. 


\section{CHAPTER I I}

\section{SITE DESCRIPTIONS}

The descriptions which follow contain only the information used in making the analytical comparisons presented in this study. The primary source of information is cited in Table I. The reader is advised to consult these references for more detailed information. Other sources of information are cited in the text. Evaluations of the importance of specific animals in the faunal collections are the cited authors', not my own.

\section{BOARDWALK (Gb To 31)}

I will refer to Boardwalk in this study as "031", which is the designation used in the laboratory during the Prince Rupert Harbor Artifact Analysis Project. I will also refer to the other two unpublished Prince Rupert Harbor sites by their lab designations. I hope that this practice will remind the reader that these sites are the main concern of this thesis.

031 is the most studied, and most well-known of the Prince Rupert Harbor sites (see Figure 2). It is a large she $11 \mathrm{midden}$, about $140 \mathrm{~m}$. $x 50 \mathrm{~m}$. and about $2 \mathrm{~m}$. deep (Archer 1984, p. 134). It is on the protected east side of 
TABLE I

SOURCES OF ARTIFACT INVENTORIES USED TO CREATE REVISED TYPOLOGIES

\begin{tabular}{|c|c|c|}
\hline Yakutat Bay & de Laguna 1964 & $p p \cdot 85-187, p 1$ \\
\hline Grant Anchorage & Simonsen 1973 & $\begin{array}{l}\text { pp. } 44-61, \mathrm{fig} . \\
16,17,18,19, \\
20,21\end{array}$ \\
\hline O'Connor & Chapman in Hobler 1982 & $\begin{array}{l}\text { pp.90-114, } \\
\text { Table } 3.10\end{array}$ \\
\hline Belcarra Park & Charlton 1980 & $\begin{array}{l}\text { pp. } 31-49 \\
\text { Table } 1\end{array}$ \\
\hline Duke Point & Murray 1982 & $\begin{array}{l}\text { pp. 134-315, } \\
\text { Table } 1\end{array}$ \\
\hline Georgeson Bay & $\begin{array}{r}\text { Haggarty and } \\
\text { Sendey } 1976\end{array}$ & $\begin{array}{l}\text { pp. 18-60, } \\
\text { Table III }\end{array}$ \\
\hline Montague Harbor & Mitchel1 1971 & $\begin{array}{l}\text { pp. } 92-212, \\
\text { Table XVI }\end{array}$ \\
\hline Little Qualicum & Bernick 1983 & $\begin{array}{l}\text { pp. } 242-254, \\
\text { Table III }\end{array}$ \\
\hline Hesquiat & Calvert 1980 & $\begin{array}{l}\text { pp. } 133-140, \\
\text { Table } 10\end{array}$ \\
\hline & $\begin{array}{l}\text { McMillan and } \\
\text { St. Claire } 1982\end{array}$ & $\begin{array}{l}\text { pp. } 61-123, \\
\text { Table } 29\end{array}$ \\
\hline Cattle Point & King 1950 & $\begin{array}{l}\text { pp. } 42-63, \\
\text { Tables } 7,9,10\end{array}$ \\
\hline Skwikwik & Onat 1980 & Tables $6,7,8$ \\
\hline
\end{tabular}

Digby Island, facing Dodge Cove at about 54 degrees north latitude (see Figure 3 ). This is in the ethnographic territory of the Tsimshian, which also included the Nass River and its rich eulachon run. Radiocarbon dates show that it was occupied before 4,000 B.P., but the heaviest occupation is from about 3,500 B.P. to 1,500 B.P. The site was abandoned in the 18th century (MacDonald 1976). 031 was excavated in 1968, 1969, and 1970 as part of the North Coast Prehistory Project. 2,249 bone and antler artifacts were 


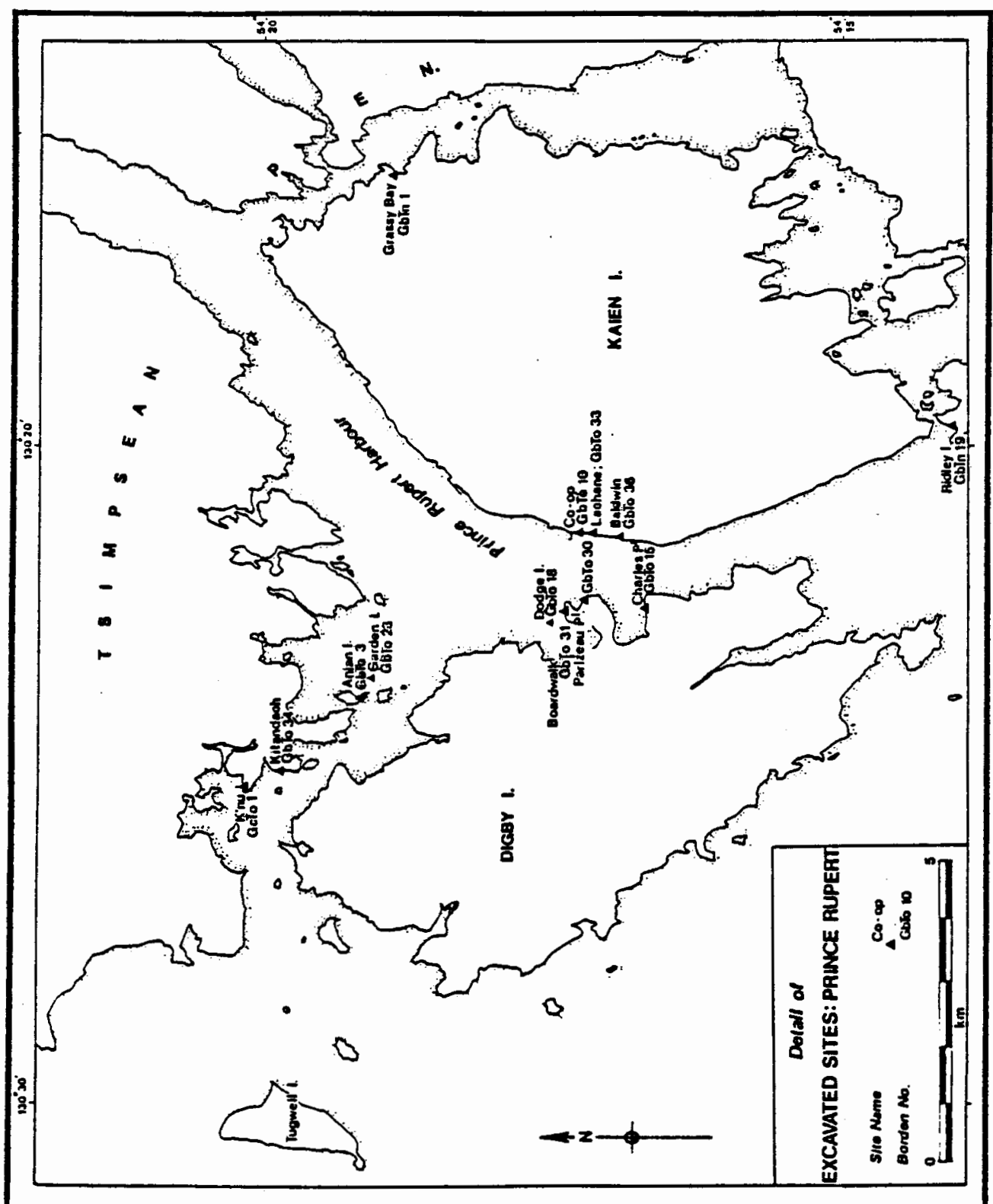

Figure 2. Excavated sites in the Prince Rupert area. From Archer, 1983. 


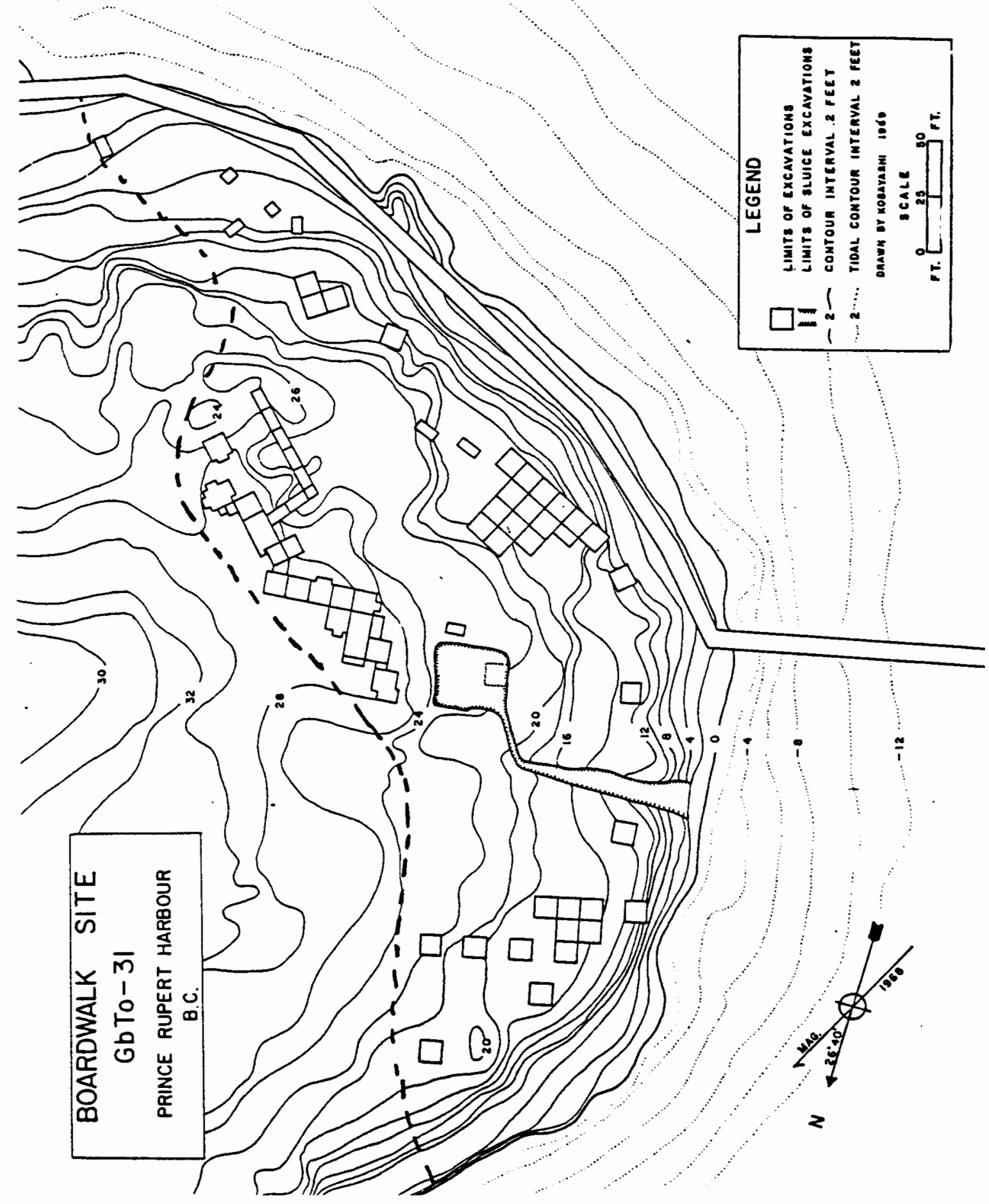

Fiqure 3. Boardwalk site, GbTo 31. 
recovered. Of these, 1,643 were classifiable and used in the present study. At $73 \%$, this is the highest percentage of bone artifacts identified of the three Prince Rupert sites. The artifacts were in good condition.

Frances Stewart's 1977 faunal analysis of 031 indicates that fall, winter, and spring were the seasons of heaviest use. There was some light usage during the summer, as well. of the 23 species of 1 and mammal identified at 031 , eleven are not native to Digby Island, and three of these (moose, caribou and Dall sheep) are not native to Coast Tsimshian territory (Cowan and Guiguet in F. Stewart 1977; however, Allaire, MacDonald and Inglis 1979 , p. 74 state that caribou are to be found in Kitselas Canyon, ethnographic home of the "inland" or "canyon" Tsimshian). Sea mammals were also included in the faunal collection. The most common was sea otter, represented mainly by their teeth. One burial contained 209 sea otter teeth, requiring at least 26 otters (based on the number of upper right 3 rd premolars--see $F$. Stewart 1977, pp. 59-60).

Unfortunately, fish bones were not systematically collected at 031 , although they were present. The shallow waters near the site are frequented by flatfish in the winter months. Herring spawn there in February, March and April (F. Stewart 1977).

Two rows of plank houses have been identified at 031. Midden accumulated between these structures and behind the 
last row. Many burials were found in the midden, at least four of which were accompanied by whole, articulated dog skeletons. Grave goods indicated status differentiation (MacDonald 1983).

031 has fresh water year round and is near a red cedar forest. The vegetation includes many berries, ferns, and bulbs. A rich intertidal zone at and near the site provide plenty of shellfish and allows easy landing of canoes.

\section{GARDEN ISLAND (GbTO 23)}

Garden Is land, or "023" was excavated in 1966 and 1967 as part of the North Coast Prehistory Project (see Figure 4). 1,353 bone artifacts were recovered. Of these, 618 were classifiable and used in this study. Radiocarbon dates indicate occupation from about 3,600 B.P. to about 900 B.P. (MacDonald and Ingl is 1980).

The island itself is very small, measuring about $400^{\prime} x$ $100^{\prime}$ (this and most of what follows is from Ames 1976). The site covers the island with a shell midden that is ten to twelve feet deep. There are aboriginal canoe skids in the intertidal zone on one side of the island. Excavations were undertaken on the opposite shore.

Garden Is land lies where narrow Venn Passage meets Prince Rupert Harbor. It is one of a few islands arising from a shallow shelf which grows thick with seaweed (Hoos 


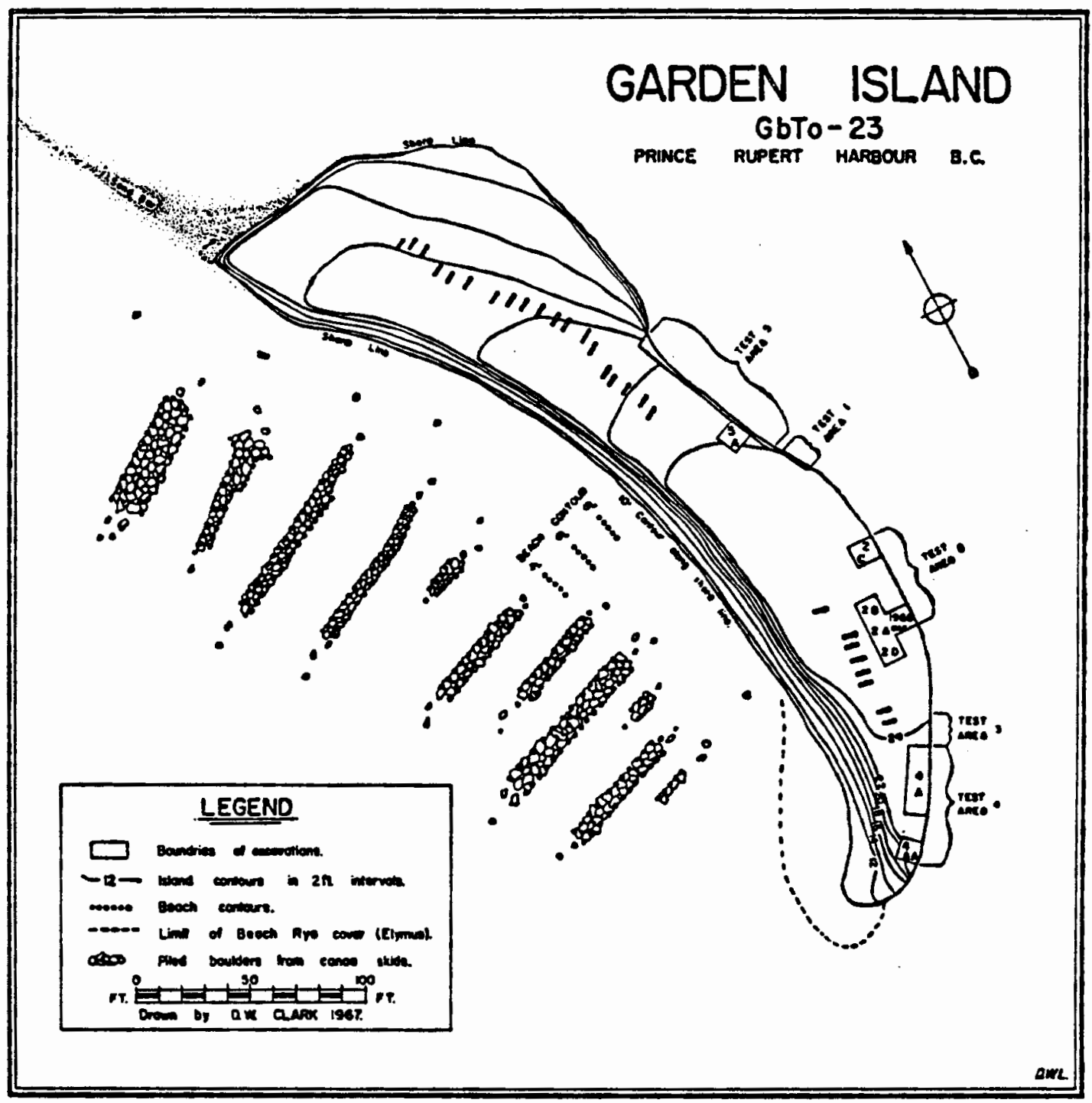

Figure 4. Garden Island site, GbTo 23. 
1975). This seaweed forms a habitat enjoyed by herring and other small fish.

Archeological features included hearths, some of which showed evidence of use over a long period. In fact, hearths were the most common feature at this site. Pits and post holes were also encountered. Their number and arrangement suggest drying racks, but no evidence of 1 arge structures was found. Burials at the site included a mass burial of seven individuals.

The 023 faunal material has not yet been analyzed.

$$
\text { GRASSY BAY (GDTO 1) }
$$

Grassy Bay, or "TN1", is a small shell midden, measuring only $57 \mathrm{~m}$. $\times 60 \mathrm{~m}$. and about 1 meter deep (see Figure 5). It is on the sheltered east coast of Kaien Island, on a small bay. Kaien Island is separated from the Tsimpsean Peninsula by Fern Passage, which is less than $100 \mathrm{~m}$. wide in places. David Archer (1984) recorded 21 shell midden sites on this northeast coast of the island, most of which are much larger than TN1.

The only feature reported at this site is the cairn burial of a child. Field notes do not indicate that any grave goods accompanied this burial (MacDonald 1968).

Preliminary faunal analys is has been performed on the TN1 collection (Hull 1980, Ames 1986). This sample is 


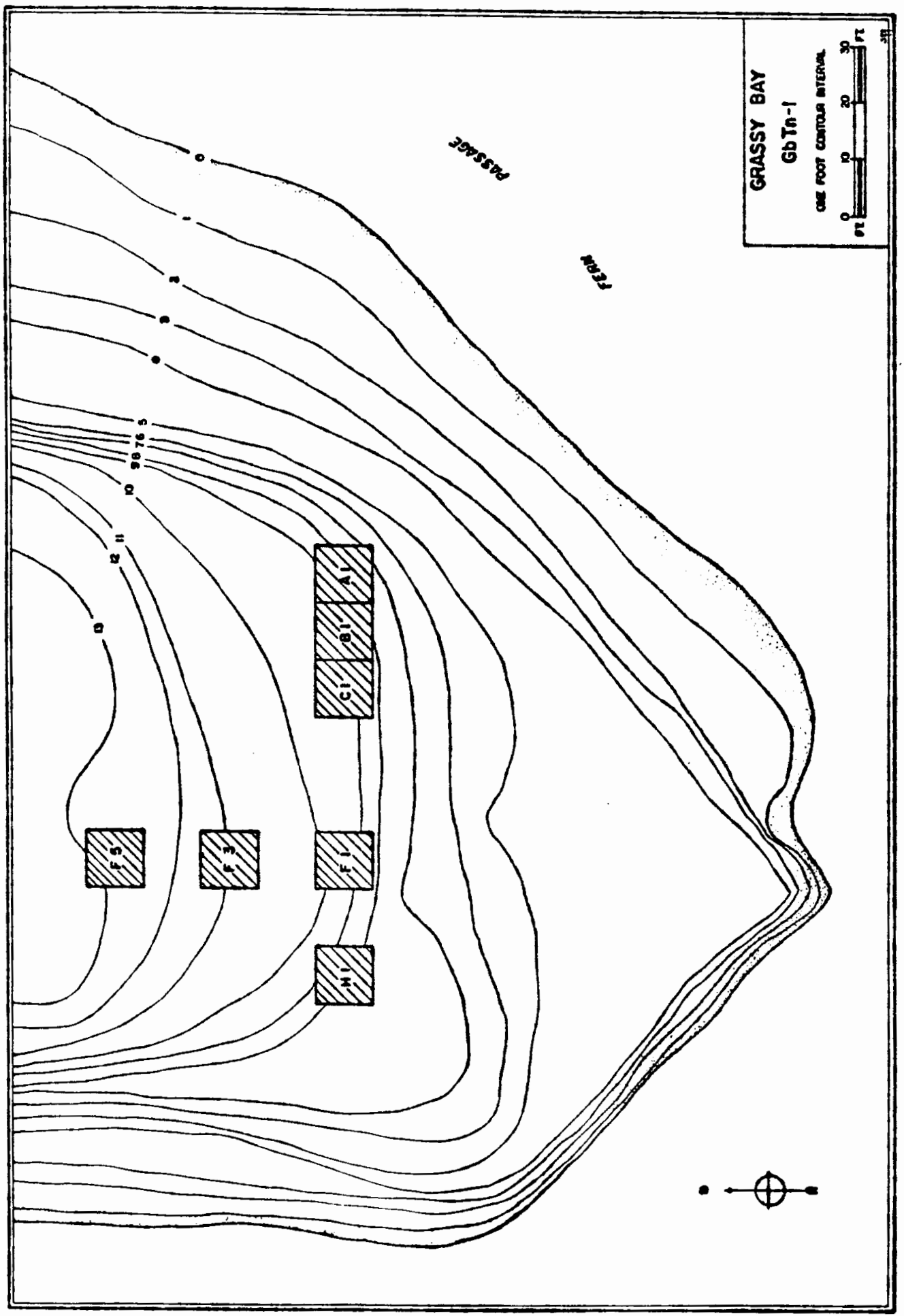

Figure 5. Grassy Bay site, GbTn 1. 
characterized by a large number of harbor seals, most of them quite young. It also contains a large number of birds, mainly rhinoceros auklets.

Radiocarbon dates at ca. 1,700 B.P. and Ca. 800 B.P. make this a late Middle Period and Late Period occupation (MacDonald and Inglis 1980).

\section{YAKUTAT BAY ("OLD TOWN")}

This site in southeast Alaska was excavated in 1952 and 1953 under the direction of Fredrica de Laguna (see Figure 6). It appears to be a late prehistoric-early protohistoric village site. De Laguna assigned dates of ca. 1,000 B.P. to its abandonment in 1791. While the weather here is somewhat more severe than that of the other sites considered in this study, it is within the range of Northwest Coast climate. Yakutat Bay lies within Tlingit territory.

The shell midden covers a $400 \mathrm{ft} . \times 500 \mathrm{ft}$. area and is two to three feet deep. It lies on the southernmost tip of Knight Island across a narrow passage from the mainland and has fresh water in the form of a stream adjacent to the site. Knight Is land is tucked well back into Yakutat Bay and the site is further protected by the body of the island. The site is known as both "01d Town" and "Yakutat Bay". I will use the latter here.

Faunal analysis indicates that harbor seal was the most commonly utilized mammal at Yakutat Bay, accounting for 778 


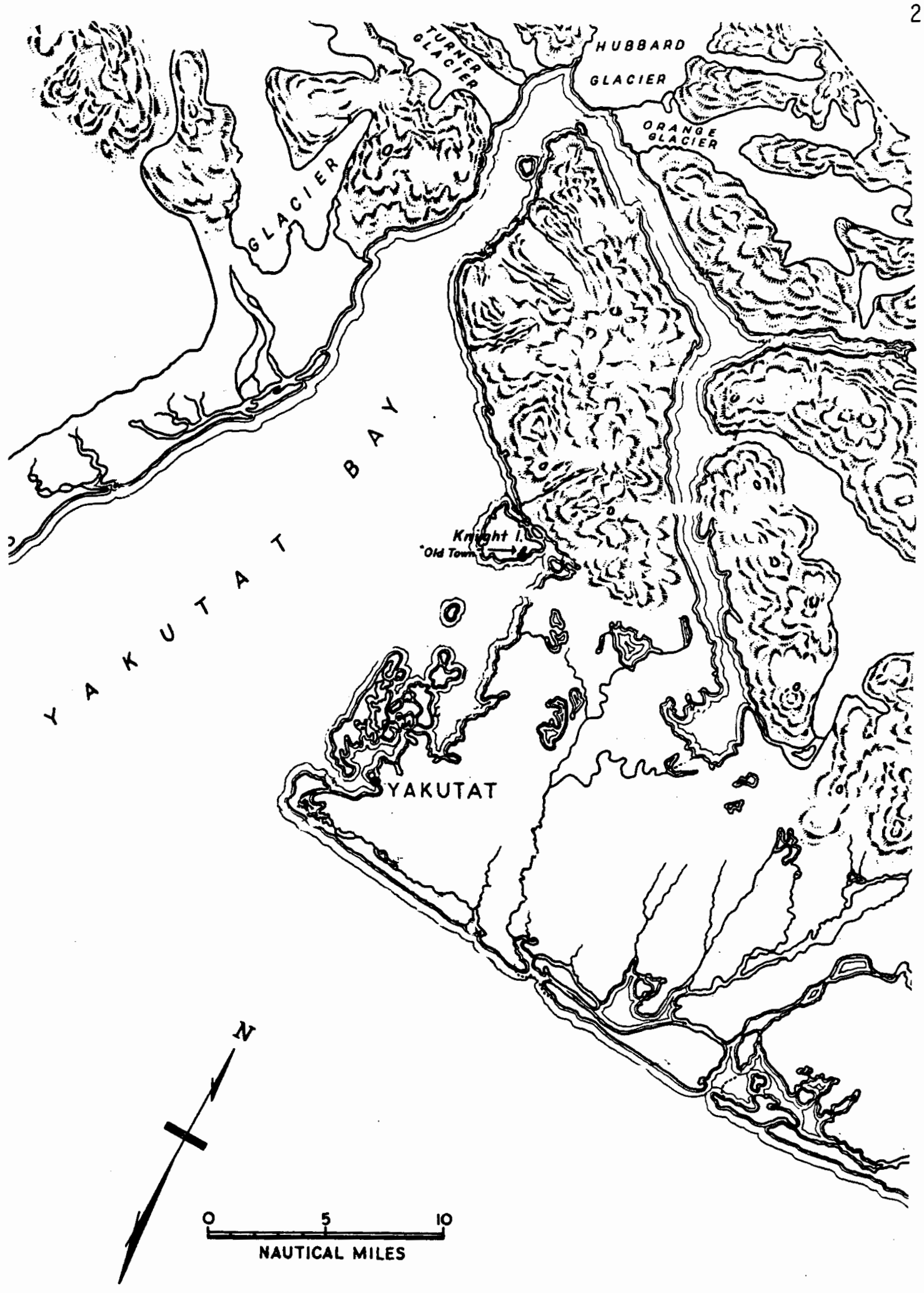


of 960 unmodified mammal bones. Also common were porpoise, with some mountain goat and sea otter in the sample, as we 11. Neither deer nor elk live in the woods near Yakutat Bay. The only available large land mammal is bear, which were hunted in the winter and spring. Fish bones were not collected during excavation due to their poor condition.

The seasonal round at Yakutat Bay in historic times included going away to Dry Bay and the Situk River for salmon and eulachon, then to Icy Bay for a second eulachon run and for sea otters. Locations around Yakutat Bay were used to hunt seals, catch halibut, herring, and salmon, hunt bear and mountain goat, and to collect plant foods. Shellfish were abundant, varied, and easy to collect. Birds were also available in great numbers.

Features at the site include many large, semisubterranean plank houses. Storage structures were also partly underground, lined with planks extending up above ground level. Midden mounds, house, and storage structures were excavated. The artifact assemblage from Yakutat Bay is consistent with those from other Northwest Coast sites. The one notable difference is the lack of deer bone and antler. There may have been a greater dependence on wood as a tool medium than in other areas. 


\section{GRANT ANCHORAGE (FCTe 4)}

Grant Anchorage is a shell midden site on the north end of Price Island, in Milbanke Sound. This is at the southernmost extent of the coast Tsimshian territory, an area not well-known ethnographically. It was excavated by Simonsen in 1969.

Grant Anchorage lies in one of the small bays which make up the jagged north coast of Price Is land and faces narrow Higgins Passage. Across this passage is the western portion of Swindle Island. The site is thus protected from the brunt of the Hecate Strait weather (see Figure 7 ).

The midden is about $150 \mathrm{~m}$. $\times 30 \mathrm{~m}$., with an average depth of $2.5 \mathrm{~m}$. (see Figure 8 ). The site has no permanent water supply, though two small periodic streams border the site during rainy periods. Trees are mainly hemlock, spruce, and red cedar. Other foliage includes salmonberry and wild rose.

Features at Grant Anchorage included charred wooden planks and a wooden tray, both from $1.5 \mathrm{~m}$. below the surface. No burials were encountered, though scattered human remains were found. The later component shows evidence of house structures.

Site occupation is dated from about 3,500 B.P. to its abandonment after contact with Europeans. This is supported by radiocarbon dates and by the presence of historic 


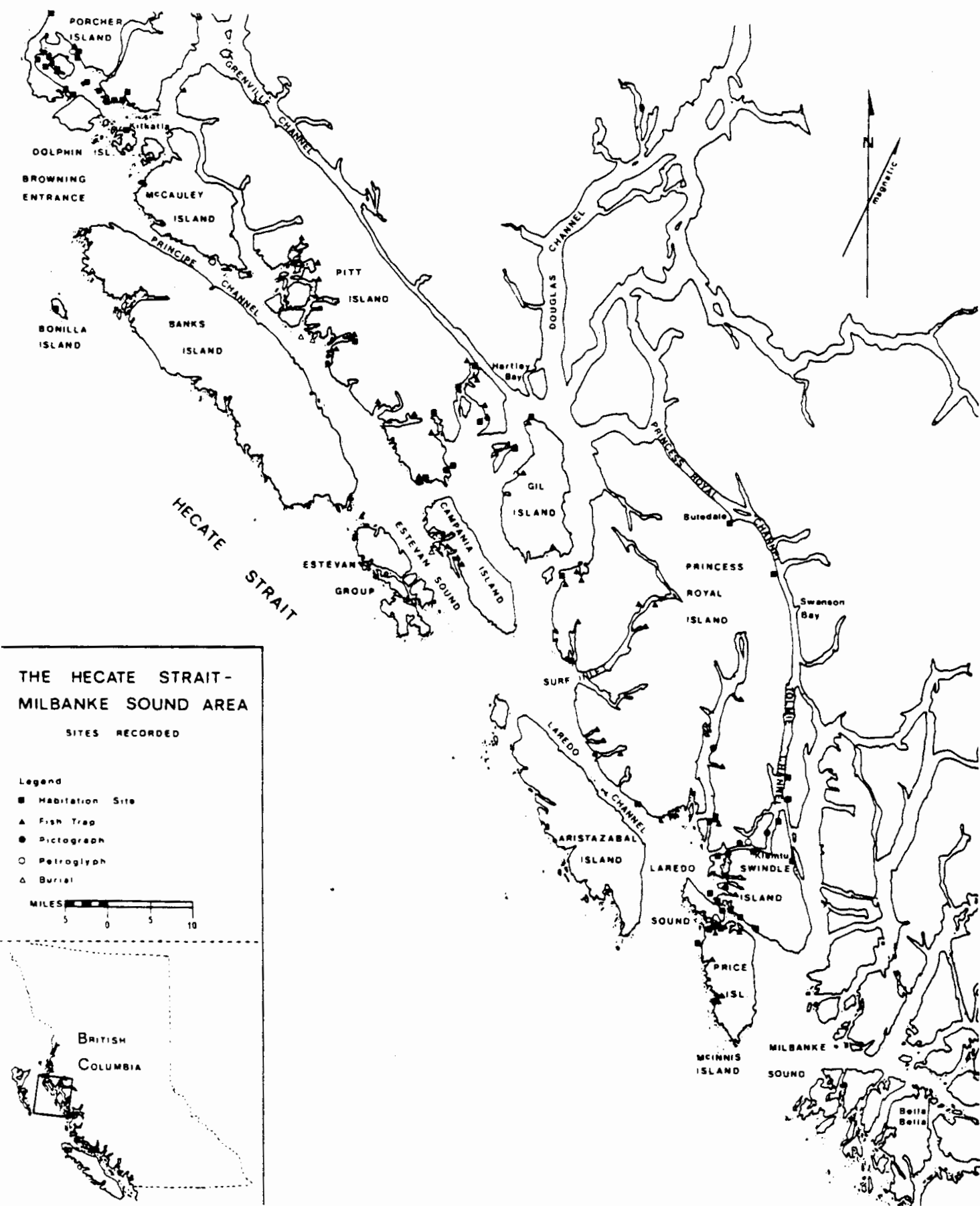

Figure 7. The Hecate Strait - Milbanke Sound area. From Simonsen 1973. 

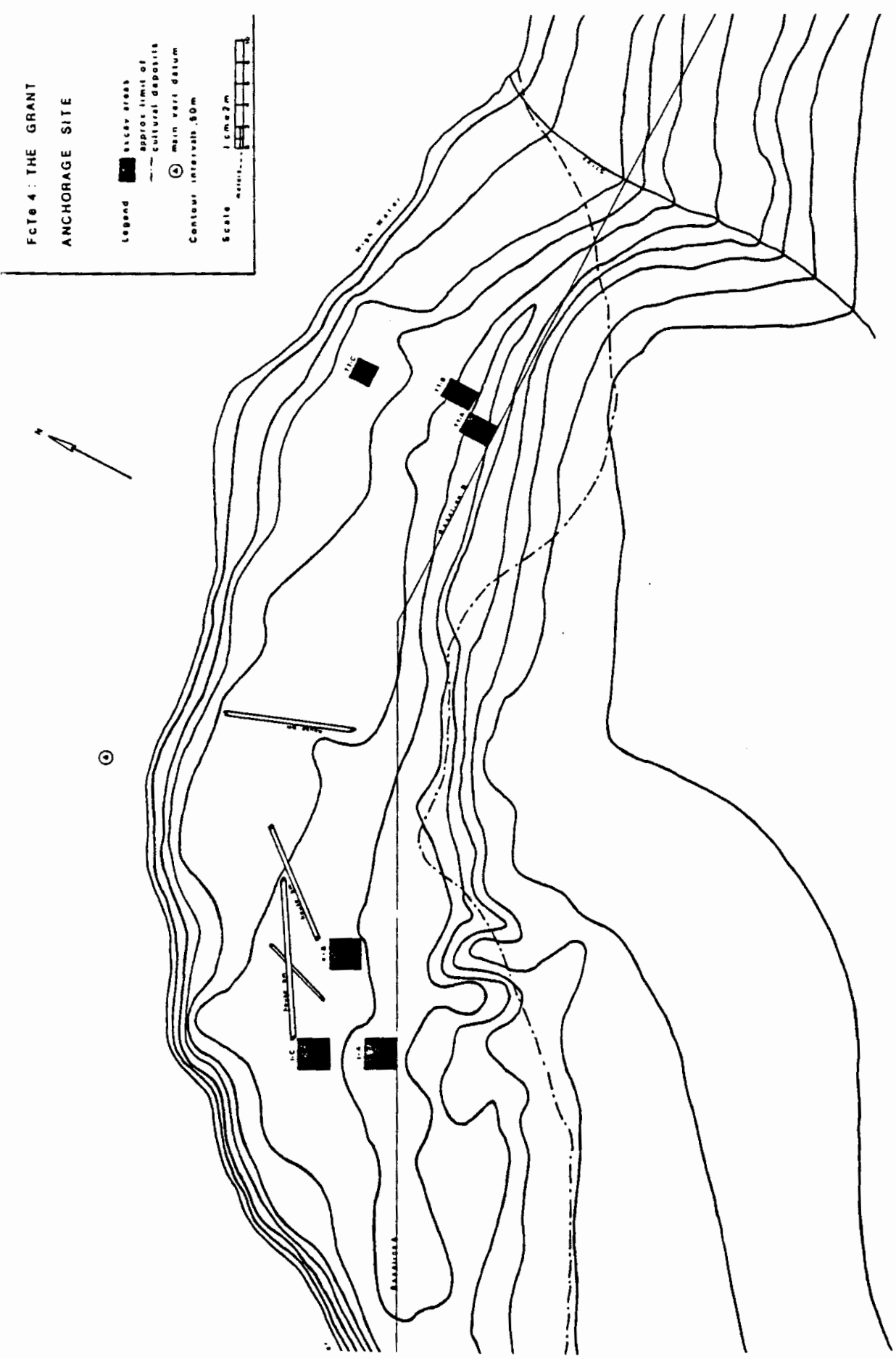

Figure 8. Grant Anchorage site, FcTe 4. From Simonsen 1973. 
artifacts. Simonsen reports that the faunal analysis reveals a 1 and and littoral subsistence strategy. While there are no large rivers nearby, short streams in the vicinity support small runs of salmon. Also, stone tidal fish traps are numerous in this area.

\section{O'CONNOR (EeSu 5)}

The O'Connor site is on a small point on the east side of Hardy Bay (see Figure 9). This is located on the northeast coast of Vancouver Is land, in the area of the ethnographic Kwakiutl. The site is tucked well back into the bay and so is quite protected from weather off of Queen Charlotte Strait. It is adjacent to the estuary formed by the entrance of the Quatse and other rivers into the bay. The true size of the $0^{\prime}$ Connor site is not known, but it does cover at least 3,000 square meters. Average depth of the deposits is about $2.5 \mathrm{~m}$. Testing was carried out in 1971 and further excavations done in 1973. The site had been somewhat disturbed and was scheduled for destruction due to private construction.

Red cedar, hemlock, berries, and wild rose grow on or near the site. Salmon run in the quatse and other nearby streams from 1 ate April through November. Hardy Bay has large clam beds and other mollusks are also available nearby. Waterfowl are drawn to the estuary habitat. A small creek runs right through the site, providing fresh water. 


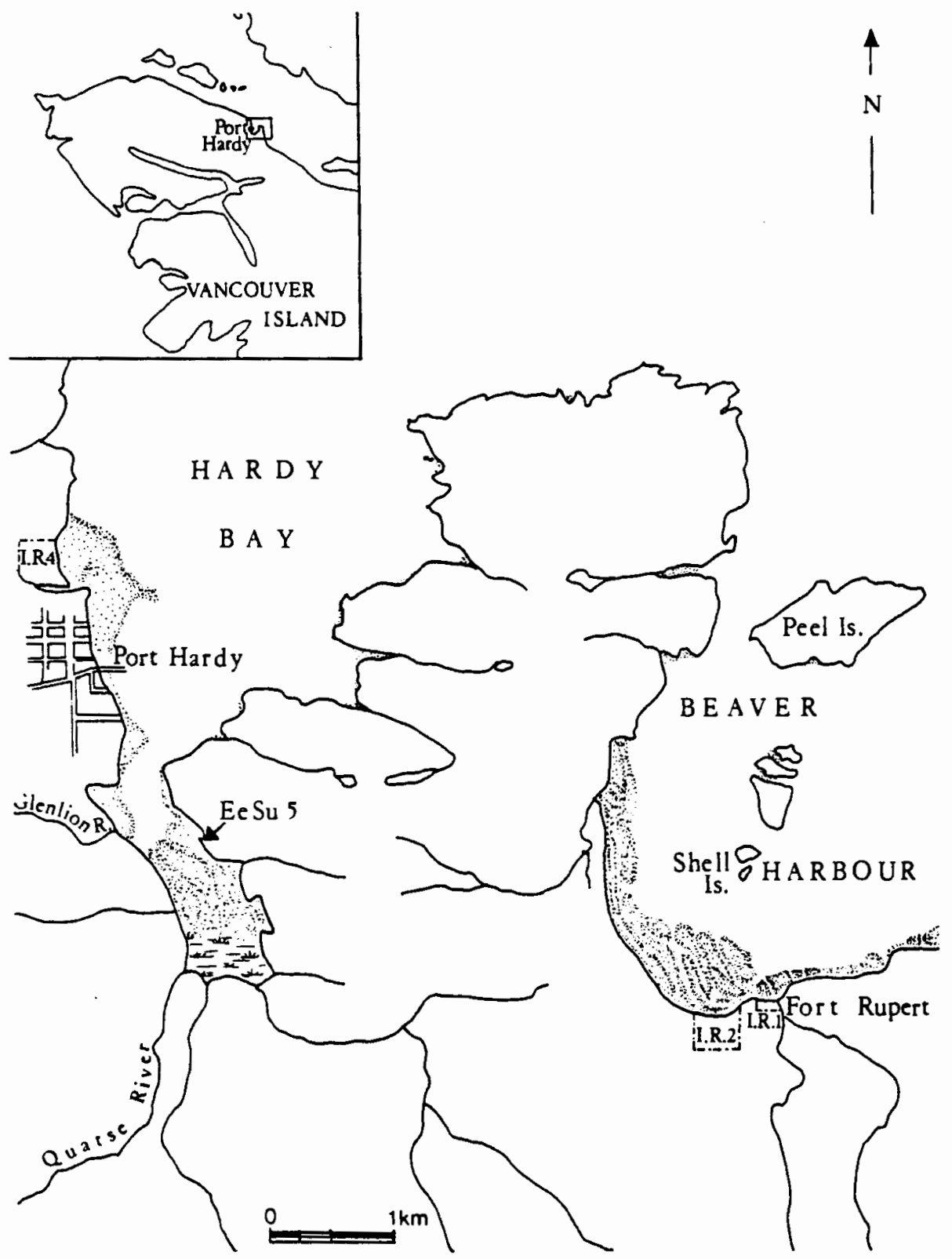

Figure 9. O'Connor site, EeSu 5. From Chapman 1982. 
Cultural comparisons and radiocarbon dates suggest a date of initial occupation sometime after 6,000 B.P., with the shell midden component beginning about 5,000 B.P. Trade goods are not present and Chapman does not advance a terminal date for the site, except that it may be later than 1,500 B.P. If these dates are correct, then $0^{\prime C}$ Connor is a Middle Period $(5,500-1,500$ B.P. $)$ site.

The only burial feature found at 0 'Connor is a disturbed burial without grave goods. Many hearths and concentrations of boiling stones were also found. Fish accounted for over $84 \%$ of the faunal material; a 11 faunal species represented at the site were probably taken in the late spring to fall time period.

\section{BELCARRA PARK (DhRr 6)}

Belcarra Park is located near the entrance of Indian Arm to Burrard Inlet--a well-protected site just north of the Fraser River (see Figures 10 and 11). Thirteen other habitation sites have been recorded in the immediate area, but none of these have been as extensively excavated as Belcarra Park. The site was excavated in 1971.

Today, the Belcarra Park shell midden measures about 150 m. $x 40 \mathrm{~m}$., but it has apparently been subjected to much erosion. The site sits just above the beach, facing south into Belcarra Bay. Prehistorically, it would have bordered the forest and the active littoral zone. Cultural deposits 


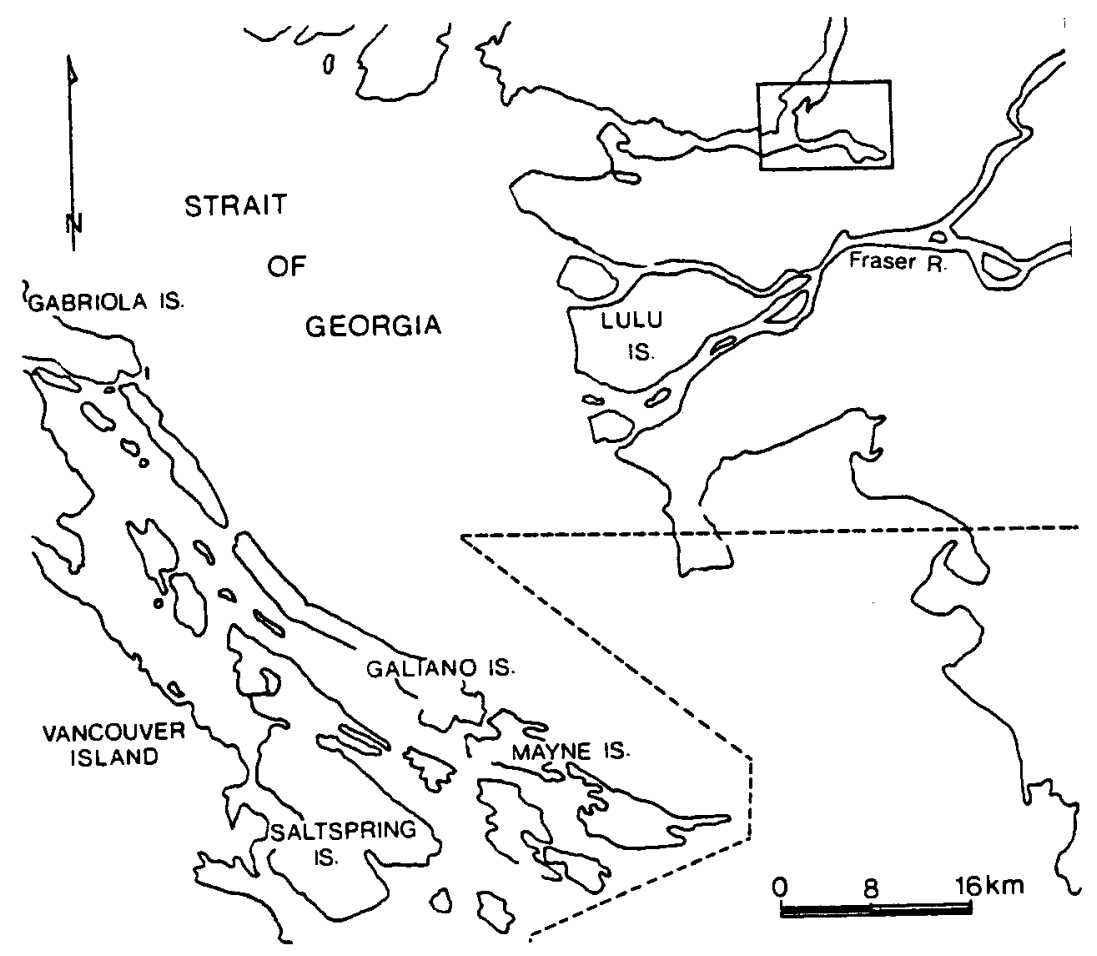

Figure 10. Strait of Georgia area. From Charlton 1980. 


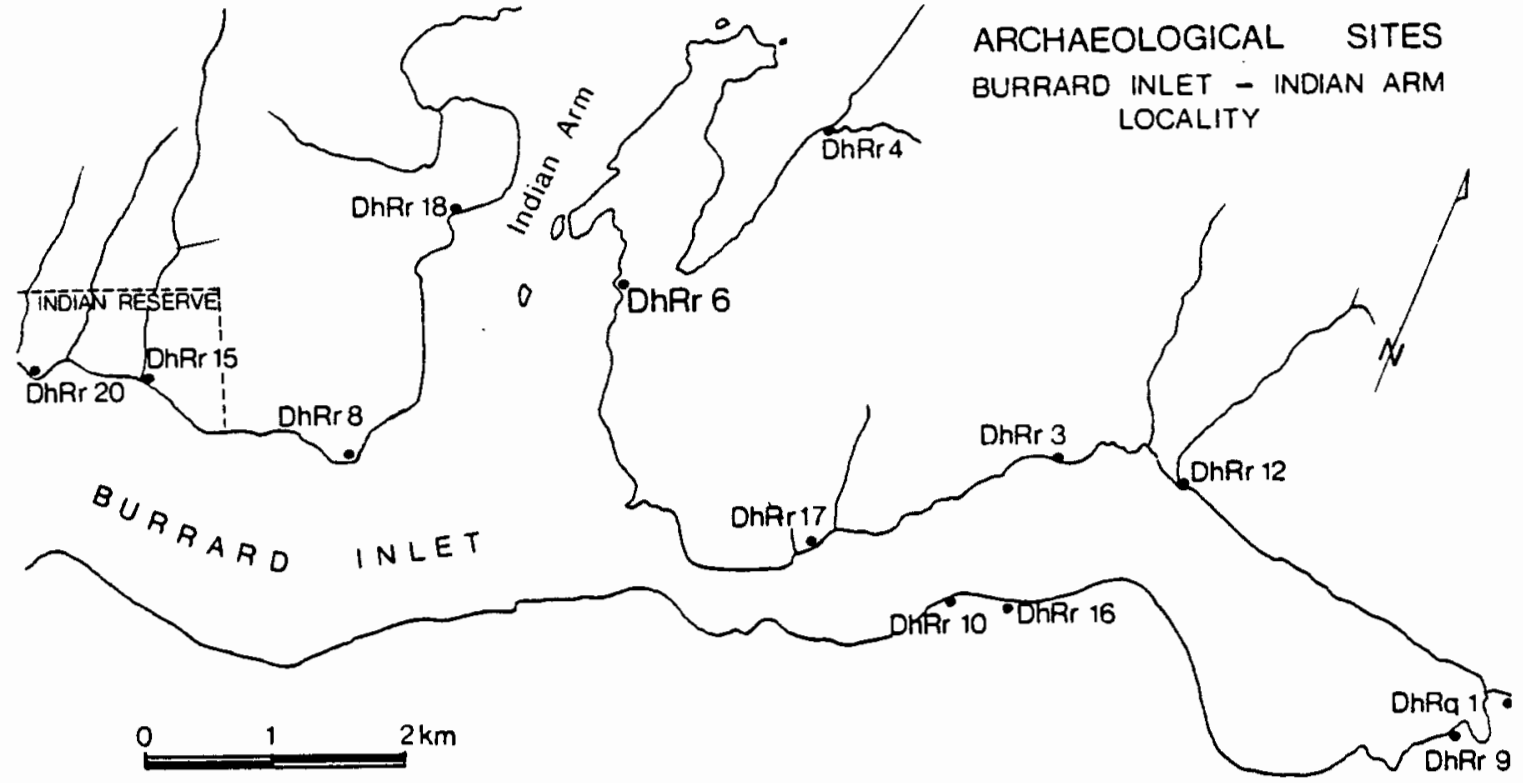

Figure 11. Area of Belcarra Park site, DhRr 6. From Chariton 1980. 
consisted of a lower, non-shell component, overlain by thick shell midden, together measuring a meter in depth.

Features at the site include large post molds and stone hearths, which Charlton feels may represent plankhouses. No burials were found. Charlton reports that preliminary faunal analysis indicates a late fall and winter occupation. Fish remains are abundant, but had not yet been analyzed. Deer, dog, and elk accounted for most of the mammals. While sea mammals were present, they constituted a minor part of the samp le.

Radiocarbon dates and cultural comparisons place Belcarra Park II (the shell component) in the Late Period (1,500 B.P. - contact). Belcarra Park I is considered to be a late Middle Period occupation, but this component adds little to the bone tool inventory.

DUKE POINT (DgRx 5, 11, 29,36)

Duke Point marks the southern boundary of the Nanaimo River estuary, on the central east coast of Vancouver Island. Many sites were recorded in this area and in 1978 these four sites (DgRx 5, 11, 29, and 36) were salvaged prior to construction of an industrial park. Excavations were conducted under the direction of D. H. Mitchell and Neal Crozier.

The four sites are located within $1.5 \mathrm{~km}$. of each other, on either side of a lagoon which bisects the point 


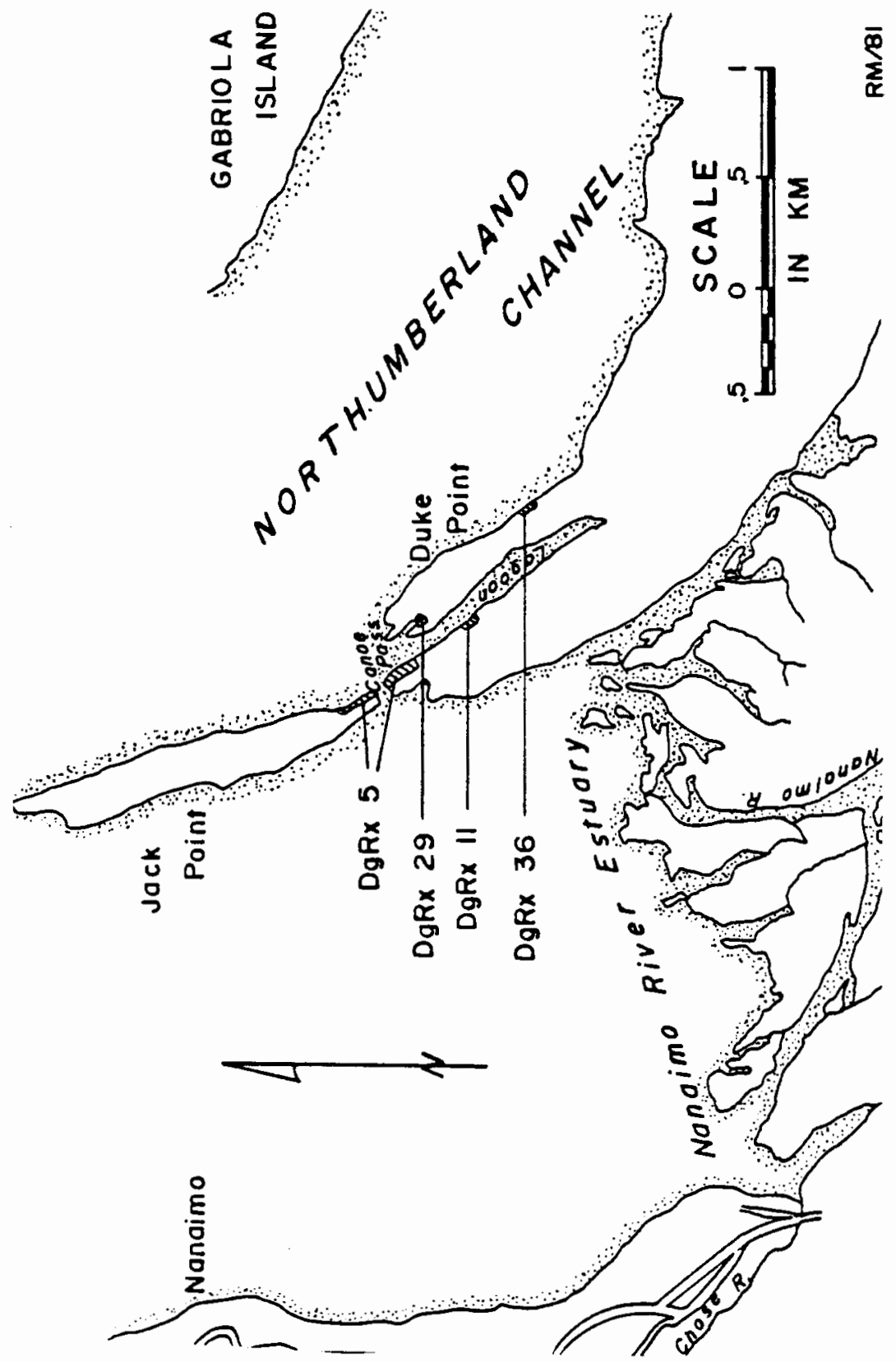

Figure 12. Duke Point sites, DgRx 5, 11, 29, 36. From Murray 1982 . 
longitudinally (see Figure 12). DgRx 5 was the largest and least disturbed of these. While the other three sites accounted for one third of the excavation units, they produced on 1 y $2 \%$ of the total artifact count. For this study, I will refer to the four sites collectively as "Duke Point".

Duke Point is protected from ocean weather by Vancouver Is land and lies in Coast Salish country. It faces the estuary, a habitat known for its diversity of life forms. The lagoon is an unusual formation, housing oysters and crabs. Many kinds of mollusk are also found here. Chum run in good numbers on the Nanaimo, as well as smaller numbers of the other four species of salmon (Murray 1982, p. 62). Spawning occurs between September and December. Herring spawn in nearby False Narrows in February and April.

Deer, elk, beaver, river otter, and bear would have been available to the prehistoric inhabitants of Duke Point. Migratory waterfowl are also attracted to the estuary. Douglas Fir dominates the forest here, with the usual very productive understory and related floral communities.

Unfortunately, the faunal analysis had not been completed and no determination of seasonality was made. Fish accounted for the largest number of bones, with salmon and herring representing the bulk of those identified. Deer and dog were prevalent among land mammals and birds were primarily waterfowl. 
A mass burial of ten individuals ranging from infant to adult was encountered and dated to before 2,500 B.P. Two children were buried wearing shell disk bead necklaces and a bone ornament (possibly a carved blanket pin) was also associated with this mass burial. No cause of death had been determined. Floors and hearths were found, but no clear evidence of large structures.

Murray concludes that these sites represent short term, seasonal occupation sites. Dates run from before 4,700 B.P. into the historic period. This is a Middle and Late Period occupation.

\section{GEORGESON BAY (DfRU 24)}

Georgeson Bay is a small bay on the southern end of Galiano Island. It lies at the western entrance to Active Pass, which is on the salmon migration route from the sea to the Fraser and other rivers. Large runs of sockeye and pink salmon go through here in midsummer (Suttles, personal communication). Three shell midden sites have been recorded on this bay, all within less than a mile of each other (see Figure 13). By far the largest, and the only one which has been excavated, is DfRu 24. A $2 \mathrm{~m}$. $\times 4 \mathrm{~m}$. test trench was excavated in 1968 by John Sendey and a small crew. At present, this is the extent of excavations at the site.

The midden at DfRu 24 is $340 \mathrm{~m}$. $\times 70 \mathrm{~m}$., with a maximum depth of about $4 \mathrm{~m}$. It faces east, into the bay. A large 


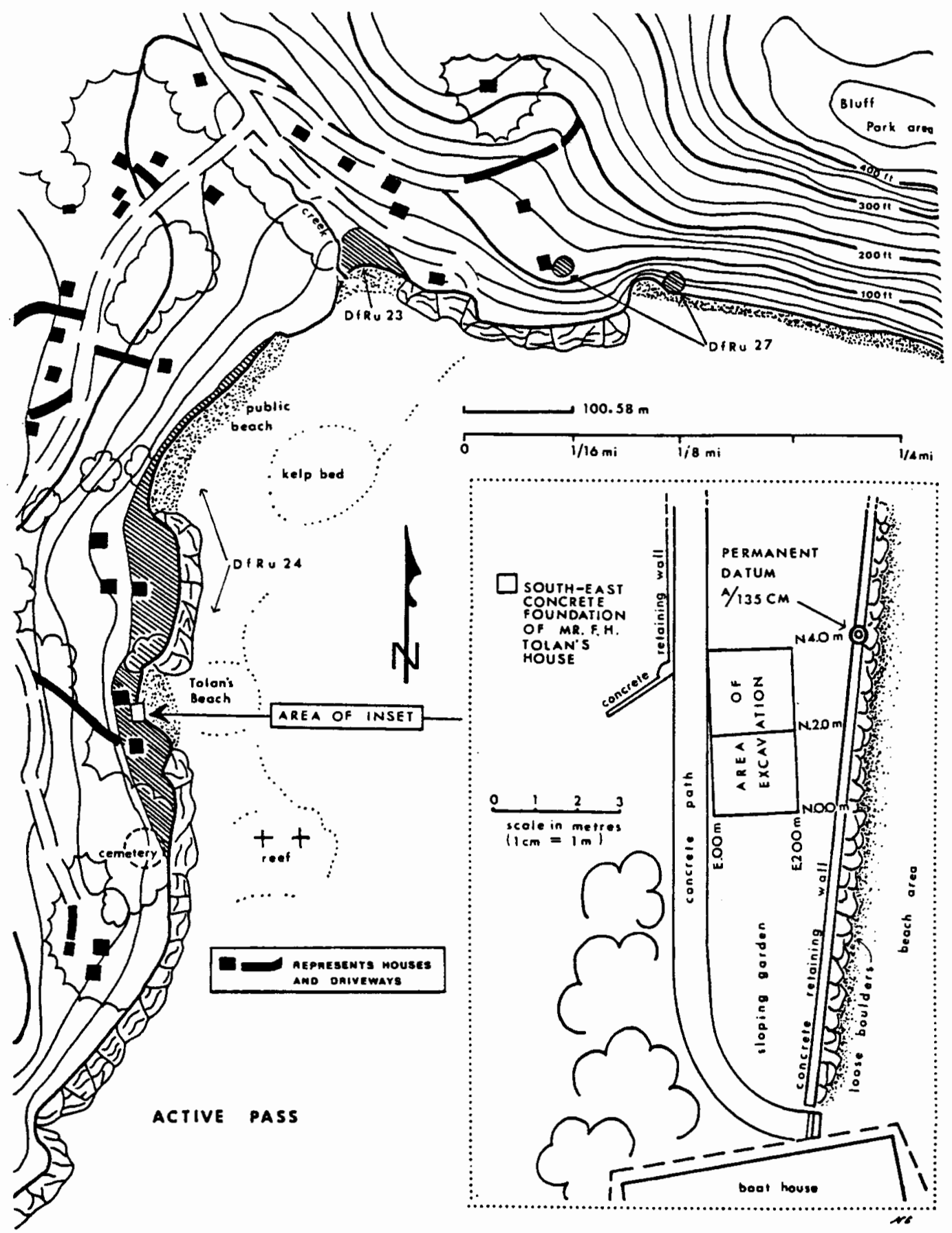

Figure 13. Georgeson Bay site, DfRu 24. From Haggarty and Sendey 1976. 
reef just offshore is exposed at low tide. A kelp bed lies north of the reef. There is also a small creek near the site.

Radiocarbon dates indicate occupation from ca. 2,800 B.P. to after 800 B.P. This is a late Middle and Late Period occupation. No clear structural evidence was encountered although a stone slab feature was uncovered. No burials were found, but scattered human remains totalled over 100 .

Fresh water from the Fraser River mixes with salt water as far as the west end of Active Pass, creating a $r i c h$ environment for plant and fish life. Remains of salmon and other fish, including lingcod, rockfish, and herring, were recovered archeologically. Halibut was expected, but not found in this test trench. Haggarty and Sendey suggest that the lack of halibut remains is due to either the use of this site in winter, while halibut were caught in late spring or early summer, or the consumption of the cooked vertebrae by the inhabitants.

Mammals used at the site were mainly deer, dog, and harbor seal. Sendey's crew often saw harbor seals hauling up on the reef near the site. The mammalian indicator of seasonality found was a piece of antler taken in the winter (C. J. Guiguet, personal communication to J. Sendey). Bird remains included loons, herons, bald eagle, the most commonly found species of gull, and ravens, all of which are year round residents. Two other species of gulls and golden eagle 
were also encountered in the deposits and these are winter species in this area.

\section{MONTAGUE HARBOR (DfRU 13)}

The Montague Harbor site lies on the northeast side of Montague Harbor, a small but well-defined harbor on the southwest shore of Galiano Is land (see Figure 14). It is about three miles, as the crow flies, from Georgeson Bay (DfRu 24). The site is so protected by the shape of the harbor and by nearby islands, that no waves reach the shores. Protected as it is from wind and waves, it is a good winter location for canoes and houses. Indeed, eight other shell midden sites have been recorded in and around this harbor. DfRu 13 is the largest of these.

The present dimensions of the site are about $700 \mathrm{ft}$. long by between $40 \mathrm{ft}$. and $100 \mathrm{ft}$. wide. Mitchell estimates that about half of the site has eroded away. Most of the present midden is $7^{\prime}-8^{\prime}$ deep. The site was tested in 1957 , when three Gulf Islands complex artifacts (unusual stone carvings, highly polished and for uses unknown) were recovered from the site. Mitchell then returned in 1964 and 1965 with a crew and conducted further excavations.

Features include a clay-lined depression, reminiscent of those at Cattle Point and at the lowest level at Helen Point, across Active Pass. Burials and scattered human 


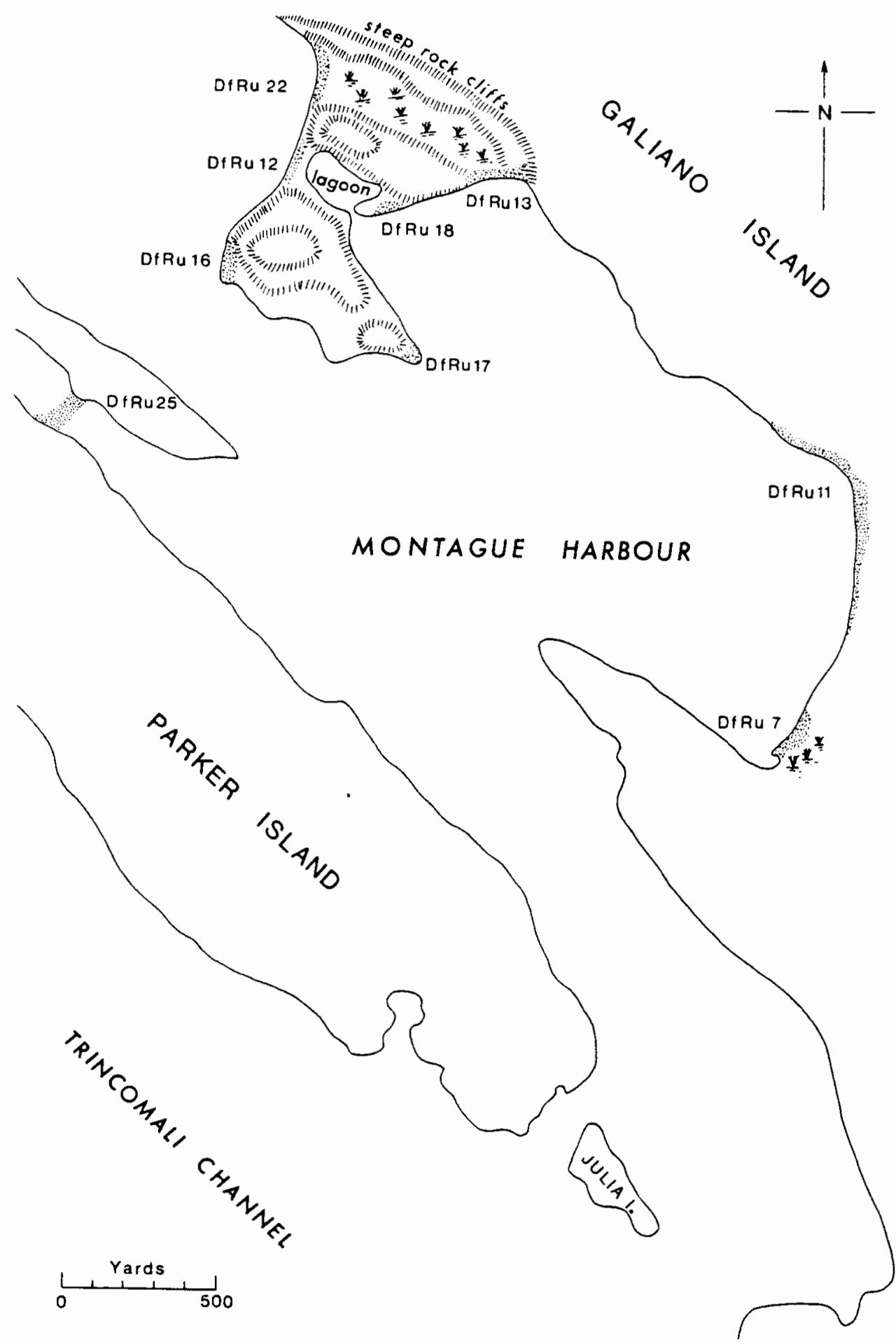

Figure 14. Montague Harbor site, DfRu 13. From Mitche11 1971. 
remains were recovered, including cairn burials and evidence of cranial deformation. One burial was accompanied by a stemmed, chipped stone point. Two large post molds were encountered, as 43 hearths.

The forest behind Montague Harbor is mainly Douglas fir and hemlock. The foliage around the site includes ferns, salmonberry and hazelnut. Deer and elk remains recovered from the midden indicate continuity with ungulate populations still living there. Seals, sea lions, and small whales enter the harbor periodically. The lagoon on the northwest point of the harbor attracts migratory waterfowl in the spring and fall.

There are no salmon runs on Galiano Island, but sockeye and pink salmon do come through Active Pass, three miles to the south, in great numbers. Lingcod, rockfish, herring, and other fish live in the harbor and in the waters nearby. Shellfish are abundant.

Faunal analysis at this site was quite limited, but some observations can be made. Deer and elk were apparently important in all levels, as were waterfowl. Salmon was present, but not abundant. Fish remains in general were numerous and increased through time. Later deposits had sturgeon remains as well. These may have been caught on the Fraser River, where they appear in much greater numbers than in the waters of the Gulf Islands. Shellfish are presumed to 
dominate the food resources in all levels. Harbor seal and harbor porpoise are also important parts of the collection. Analysis shows occupation during late fall and early spring. Montague Harbor is in Salish territory.

Radiocarbon dates indicate occupation at the site from before 3,200 B.P. and abandonment before about 1,800 A.D. This site was occupied during the late Middle and Late Periods.

\section{LITTLE QUALICUM RIVER (DiSC 1)}

Little Qualicum is a site on the east coast of Vancouver Is land, at the south end of the delta formed where the Little Qualicum River meets the Strait of Georgia (see Figure 15). This lies in the territory of the Pentlatch Coast Salish. It has a waterlogged section which is covered by high tide, and a dry section. The wet portion of the site contains little shell, while areas of the dry section are nearly pure shell. Excavation concerns at Little Qualicum were focused on salvaging areas of the site threatened by storm wave erosion. Excavation was carried out in 1974 and 1976 under the general direction of $\mathrm{Dr}$. D. H. Mitchell. Field directors were Patricia Winram and Kathryn Bernick, respectively.

The site boundaries are not clear, but testing has revealed deposits extending at least $200 \mathrm{~m}$. along the shore and $80 \mathrm{~m}$. perpendicular to the shore. Cultural depth appears to be about $1 \mathrm{~m} .-1.5 \mathrm{~m}$. Excavations revealed one cultural 


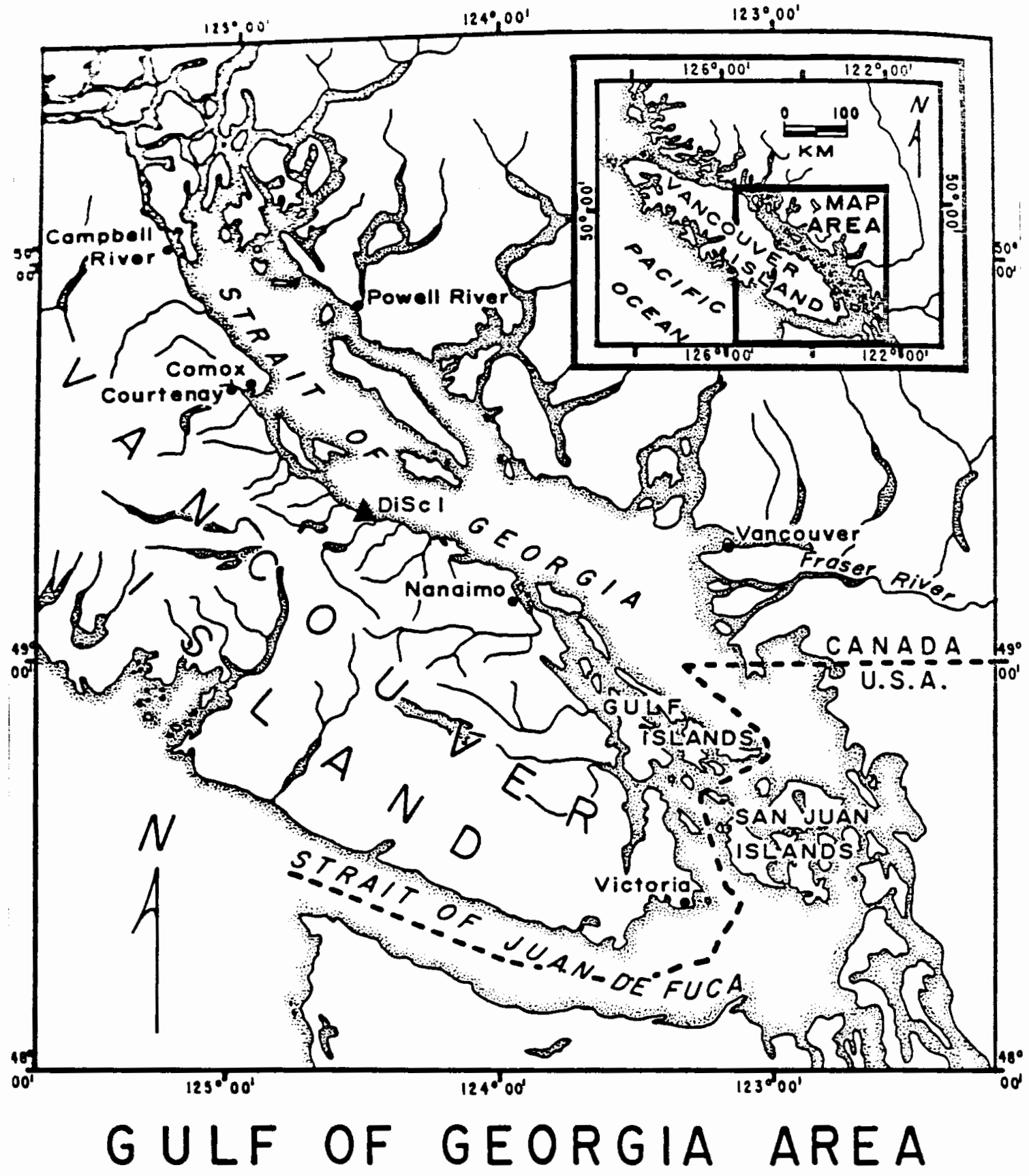

$\Delta$ Little Qualicum River site, DiSel SCALE

- Modern Settlement

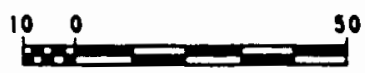

$\mathbf{R 8 / 8 0}$

Figure 15. Location of Little Qualicum River site, DiSC 1. From Bernick 1983. 
component and different activity areas. One burial, that of an infant, was recovered. There were no burial inclusions. Post molds up to $15 \mathrm{~cm}$. in diameter were found, as well as smaller post holes associated with ashy lenses and crushed she11. The shell midden was somewhat removed from the living area. Refuse from work done near the river's edge was thrown down into the river, ending up in the waterlogged deposits. Radiocarbon dates and cultural comparisons place the initial use of this site at ca. 1,000 B.P. No historic materials were found in the deposits suggesting that the site was abandoned prior to European contact. If this is correct, this is a Late Period site.

Western red cedar, Douglas fir, hemlock, and Sitka spruce were found in the wet deposits. Remains of deer and elk were present, as were harbor seal, harbor porpoise, and northern sea lion. Domestic dog remains were also encountered, as were waterfowl (mainly ducks and geese).

All five species of salmon run in the Little Qualicum River. Chum is the most abundant, spawning in 0ctober through December. In fact, the largest chum runs on the east coast of Vancouver Is land are in the Little and Big Qualicum Rivers. Salmon accounts for most of the fish remains from the Little Qualicum site.

The second most common fish in the archeological deposits here is Pacific herring. These fish come to protected inshore waters sometime between fall and early 
spring and wait to spawn. Because their stores of body fat are used up during this period, the best time to catch them for their oil is in the fall. The spawn is also prized, the eggs collected and preserved as food. "Hook and line" fish (which may also have been caught by nets or the tidal weir to be seen in front of the site) found in the sample include cods, dogfish, sole, perch, and rockfish. Bernick concludes that the Little Qualicum River site was a salmon camp, utilized for the fall chum spawning run.

\section{HESQUIAT ( $D$ iSo 1 )}

This site lies in a small protected harbor on Vancouver Is land's harsh west coast. Hesquiat Harbor, which is about $9.6 \mathrm{~km}$. deep and $6.4 \mathrm{~km}$. wide, drains several small streams and Hesquiat and Rae lakes. Many of these streams are large enough to support runs of chum, sockeye and coho salmon. The harbor is not deep, and a long silty bar forms at the seaward entrance. Great kelp beds lie in the harbor, attracting cod and other fish from the ocean. The bar attracts many bottomfish.

DiSo 1 is a shell midden site located atop a 1 ow $(8 \mathrm{~m}$. above m.s.1.) bluff on the western entrance to the harbor, which opens to the south (see Figure 16). The midden measures about $40 \mathrm{~m}$. by more than $160 \mathrm{~m}$. and averages about $1.5 \mathrm{~m}$. in depth. The materials considered in this study came from three $2 \mathrm{~m}$. $\times 2 \mathrm{~m}$. units excavated in 1972 and 1973 . 


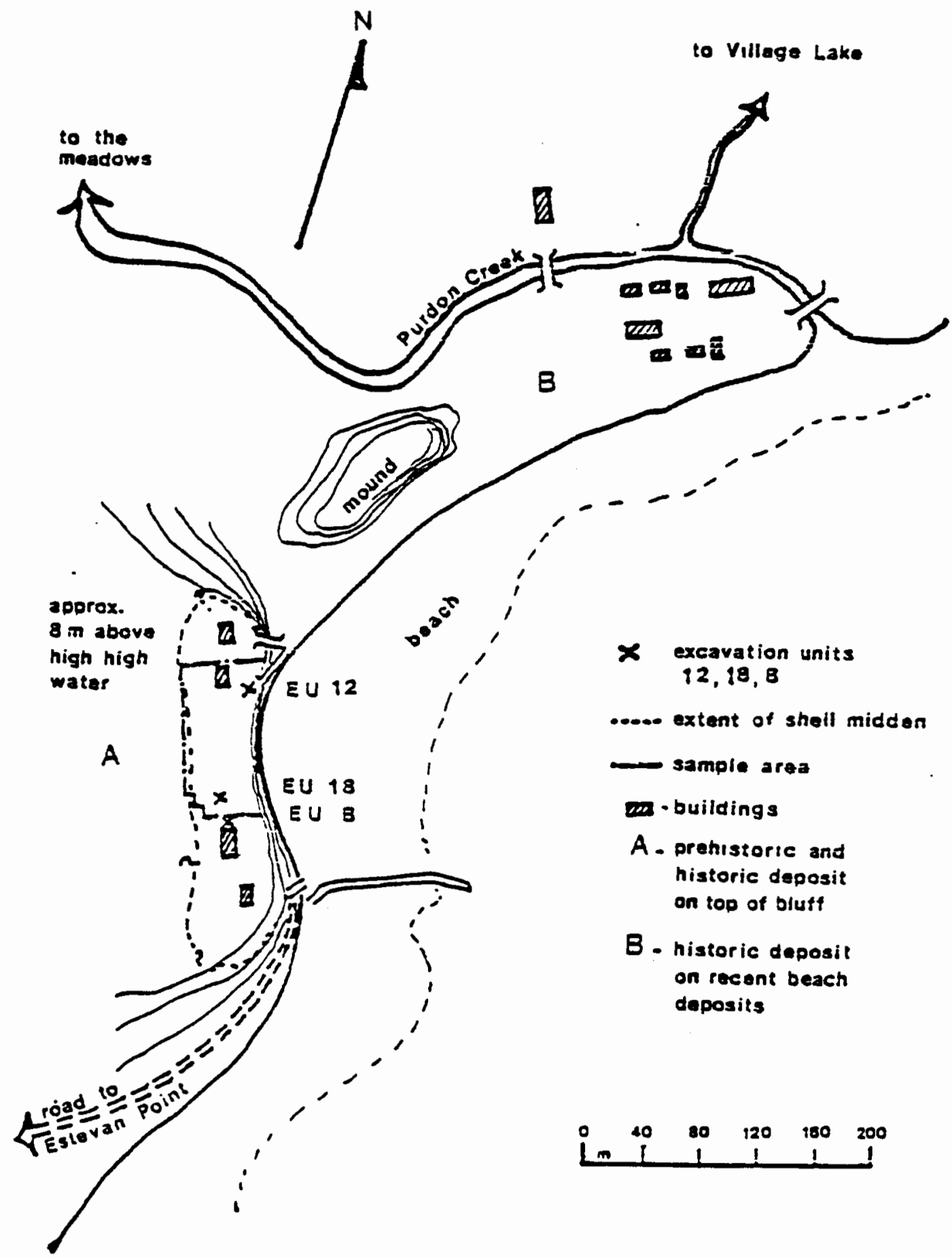

Figure 16. Hesquiat site, DiSo 1. From Calvert 1980. 
Radiocarbon dates and cultural comparisons suggest that this site was used from ca. 1,200 B.P. to about 500 B.P. This is a Late Period occupation, on traditional Nootka land.

Seasonality, as indicated by detailed faunal analysis, was year round. Faunal elements do not exhibit evidence of having been transported, as all parts of the animals are present. These mammals, fish, and birds were caught and consumed or preserved at the site. The faunal assemblage reveals the overwhelming importance of pelagic and pelagic/littoral resources at this site (probably more than $85 \%$ by animal weight).

The faunal sample was made up mostly of fish bones (about $66 \%$ of the total number). These were mainly rockfishes, while greenling and lingcod were also present. Birds accounted for a relatively high percentage of the sample as we11. Birds here comprised $16 \%$ of the collection, while at most sites considered here the total percentage is in low single digits. Albatross was the most important bird, by far. Sea mammals far outnumbered the land mammals. Seals and sea otters were the most important, while whales, dolphins, and sea lions were also present.

The study cited here is strictly concerned with faunal analysis, and so did not contain information on the presence or absence of structures or burials at DiSo 1. However, many burials are to be found in caves around the harbor. 
SHOEMAKER BAY (DhSe 2)

Barkley Sound and Alberni Inlet run from southwest to northeast across Vancouver Is land, almost cutting the is land in half. Barkley Sound is wide and jagged, opening onto the Pacific Ocean on Vancouver Island's west coast. Alberni Inlet is a long, narrow body of water which drains the Nahmint and finally the Somass River (see Figure 17). Shoemaker Bay is small and narrow, separated from the northern extension of Alberni Inlet and the Somass River delta by Johnstone Island (see Figure 18). The area of the site is a brackish wetland, low and swampy. The site has been greatly disturbed and the original perimeters could not be determined. The relatively intact portion chosen for excavation was about $60 \mathrm{~m}$. $\times 40 \mathrm{~m}$. with deposits from $0.5 \mathrm{~m}$. to a little over $1 \mathrm{~m}$. deep.

DhSe 2 is very close to marsh, estuary, river, and marine resources, as well as the forest which lies behind the site. The forest is dominated by Douglas fir, red cedar, hemlock, and Sitka spruce. Berries are found near the site and camas also grows in the vicinity. Coho, chum, chinook and sockeye salmon all run in great numbers in the Somass River and in other local streams. Herring spawn in the In let.

The Somass Delta did support clams, cockle, bay mussel, oyster, whelk, and limpets. These shellfish were important 


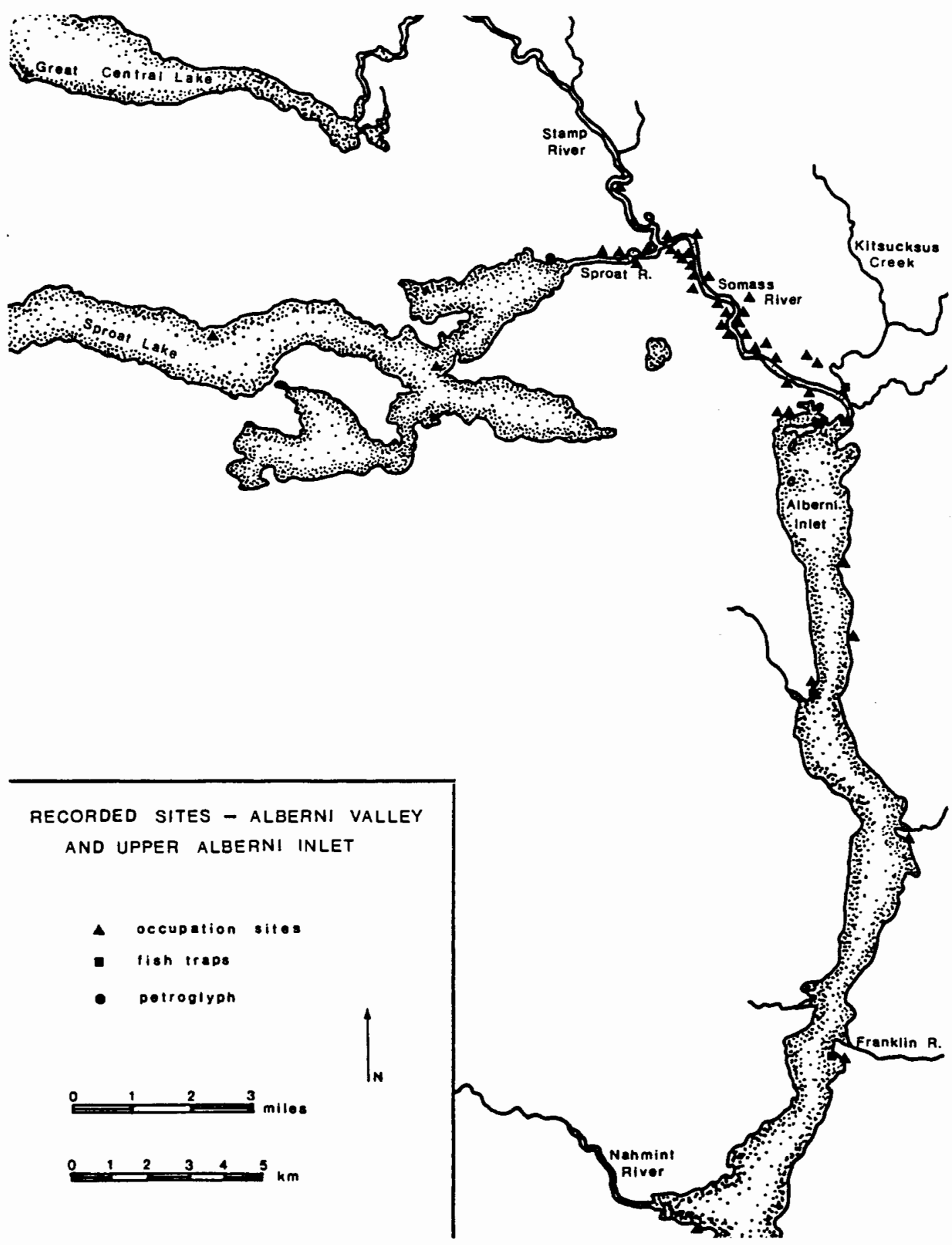

Figure 17. Recorded archeological sites in the Alberni Valley. From McMillan and St. Claire 1982. 


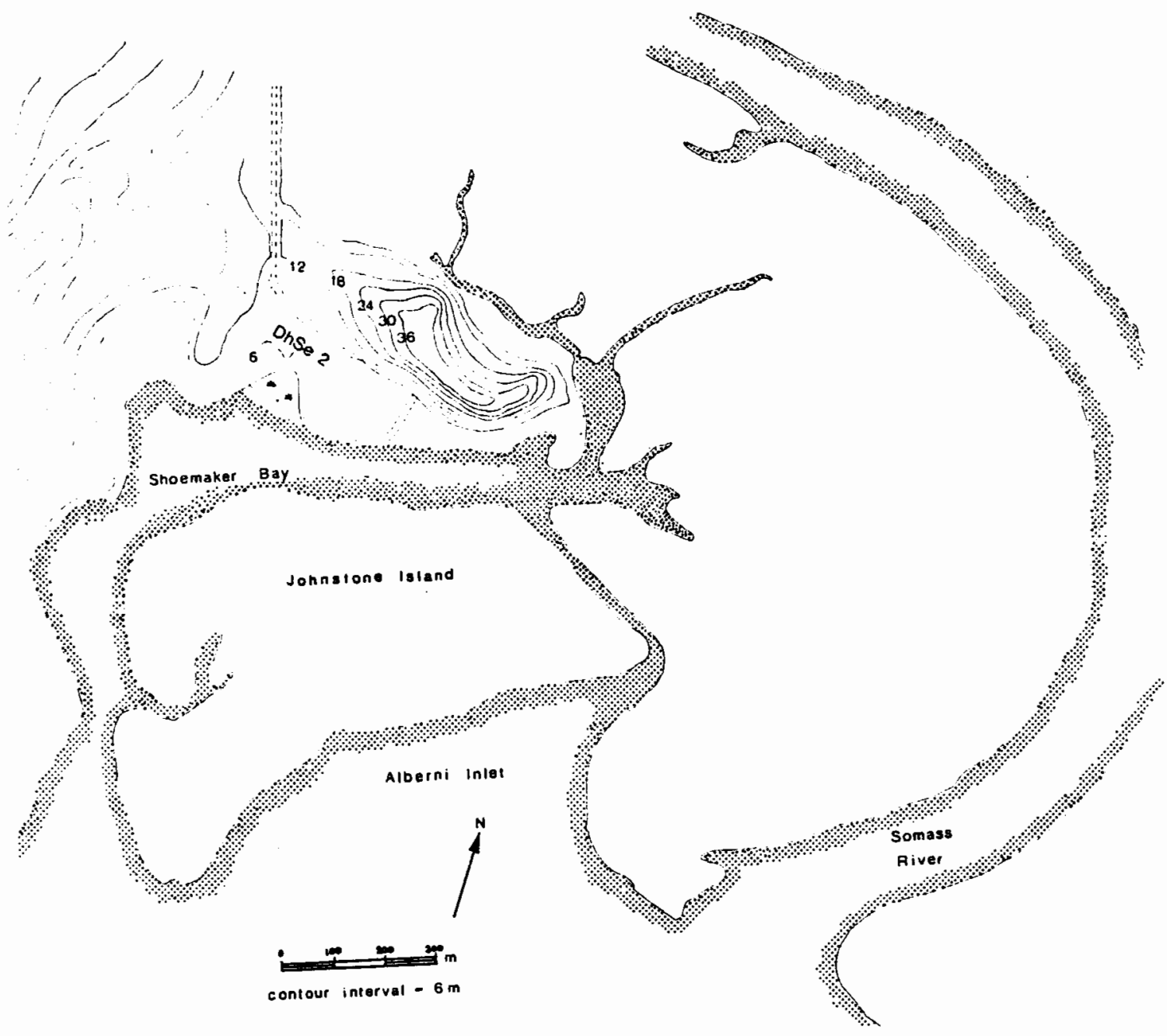

Figure 18. Shoemaker Bay site, DhSe 2. From McMillan and St. CTaire 1982 . 
archeologically in the delta, but later became extinct in the area. It remains an important habitat for migratory waterfowl, which appear in the archeological sample in abundance. Deer and elk were used at the site, as well as black bear, beaver, river otter, marmot and other 1 and mammals.

Post molds of up to 1 meter diameter were uncovered, as were stone hearths and a long rock-lined trench of unknown use. Three burials were reported, one with cranial deformation but none with clearly associated grave goods. The non-shell component contained two composite toggling harpoon heads in situ. They were in close association and were probably both part of the same $Y$-shaped salmon spear (McMillan and St. Claire 1982, pp. 79-81). The shell midden component had no burials, no post molds or hearths, but did contain an articulated dog skeleton.

The non-shell component displays a mostly terrestrial adaptation, while the shell midden component contains mostly fish, especially salmon and herring. Shellfish include a high percentage of California mussel, a species not found near the site. Tuna, whale, and marmot remains discovered at the site could only have been caught in locations distant from Shoemaker Bay.

Faunal evidence suggests year round habitation, as all seasons are represented in the collections from both 
components. Occupation appears heaviest during the late summer, fall, and winter.

The non-shell component dates to between 4,000 B.P. and 1,500 B.P., making it a late Middle Period occupation. The shell midden is dated from ca. 1,500 B.P. to the site's abandonment ca. 500 B.P., making this a Late Period component.

\section{CATTLE POINT (SU1)}

Cattle Point is located on the south end of San Juan Is land (see Figure 19), in the San Juan Archipelago. The Cattle Point site faces out onto the Strait of Juan de Fuca. It is a large shell midden site, measuring $1,800^{\prime} \times 700^{\prime}$, and is over ten feet deep in places. The site was excavated in the summers of 1946 and 1947.

This site occupies a very exposed location, but some attractive features of the setting apparently drew the original inhabitants. One of the most important salmon banks in the Strait of Juan de Fuca lies just offshore. Salmon running in to the Fraser and other rivers go by this location. Also, the beach offered a good formation for landing canoes, a rarity in these parts. King (1950, p. 3) maintains that the beaches supported shellfish in the past, though they no longer do so today. The site contains four large springs, making it the site of the best water supply on the south or west coast of the island. 


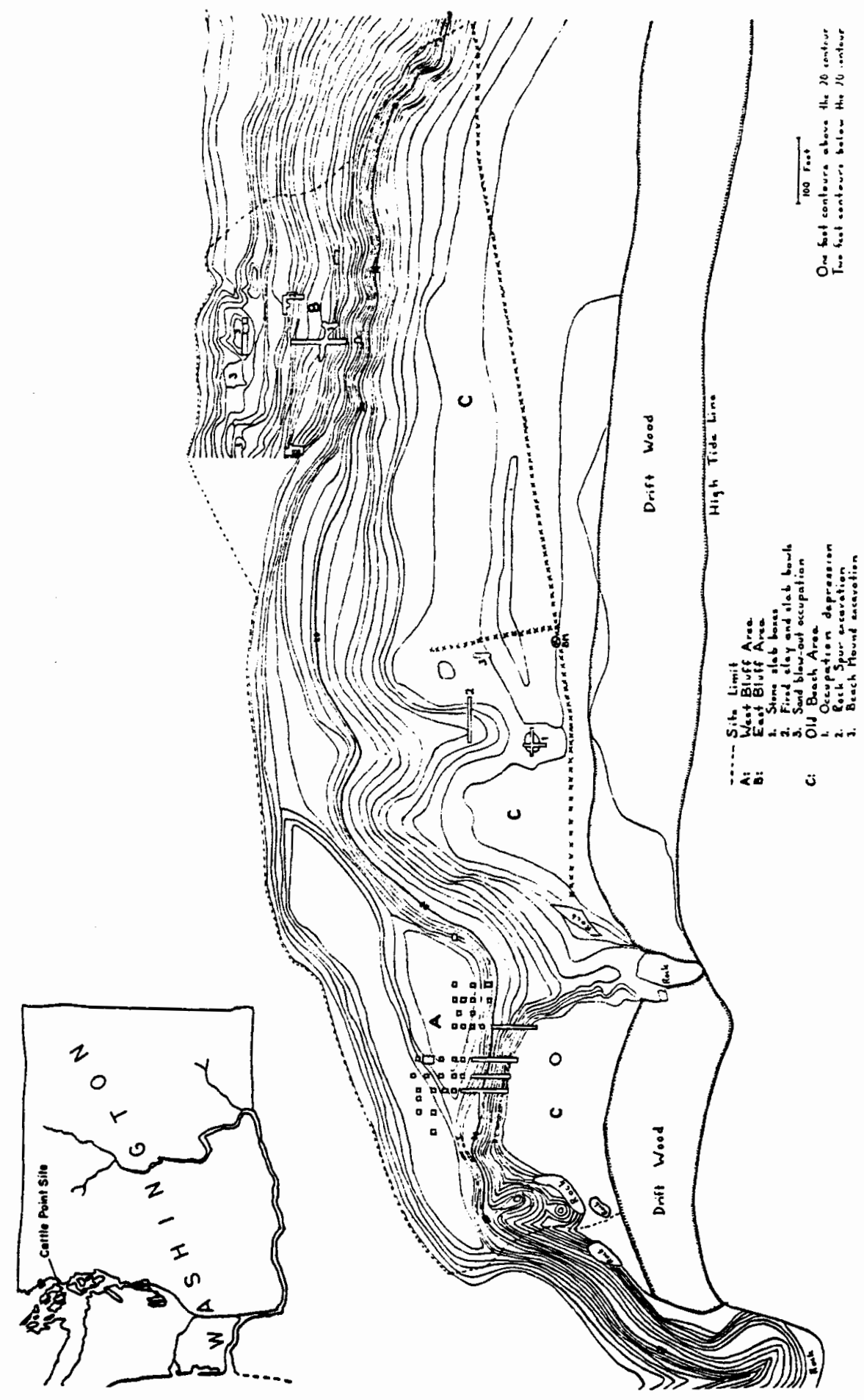

Figure 19. Cattle Point site, SJ1. From King 1950. 
King was not sure whether occupation of the site was year round or seasonal. While some faunal analysis was done, seasonality was not addressed. Unidentified fish bone was the most common faunal element, except for the mollusks which made up most of the later deposits. Clams are said to be most flavorful in early summer (Quayle 1960, p. 12), and clams account for many of the shellfish species found in the midden. The most important mammal at the site was the blacktailed deer, which were available in summer and winter in this area (Suttles, personal communication). The next most common animal was domestic dog, with half as many harbor seal remains.

Site features include burials (some with cairns), stone slab and clay slab structures. Some of the stone structures are aligned. The clay slab structures are more like large pots. Camas probably grew in abundance behind the site in prehistoric times, and they may also have been oaks nearby (Suttles, personal communication). The clay slab structures may possibly have been used in processing the bulbs and acorns. While there are natural depressions at Cattle Point which would give shelter from the winds blowing in off the strait, King felt that he had no clear evidence of plankhouse structures.

The burials were either interred in the midden or covered with flat stones. Isolated human remains were also 
found. Two associated burials had grave goods: an antler wedge, a slate knife, and a bi-pointed stone object.

Radiocarbon dates are not available for this site and King offered no estimates as to absolute age of the site. He determined four phases in the deposits. The earliest he called the Island phase, a terrestrial adaptation in a nonshell midden. The second phase, the Developmental, shows a developing marine adaptation and contains deposits of both soil and shell. Bone and antler artifact totals rise during the Developmental phase while the overall rate of deposition remains about the same. The Maritime phase has midden made mostly of shell and a full maritime adaptation. Artifact totals increase in all categories, as does the variety of forms. Intensified utilization is indicated by the faunal remains, as well.

The Late phase has a mostly shell midden and shows signs of decreased site use. The number and variety of tool types is sharply reduced, as are the faunal remains. This pattern is probably due to changes in local conditions which caused the demise of the mollusk population on the beach. It may also reflect the general demographic changes caused by contact with Europeans. This series of phases concurs with the general outlines for Coast Salish cultural development (i.e. Burley 1980), and suggests dates in the second half of the Middle Period (3,500 B.P. - 1,500 B.P.) and the early part of Late Period (1,500 B.P. - contact). 
SKWIKWIKWAB (45SK33A, 45SK33B, 45SK99)

These three sites 1 ie in close proximity on a small outcrop at the south end of the Skagit River Delta (see Figure 20). In prehistoric times, this outcrop was a small is 1 and in a marshy estuary (see Figure 21). This group of sites is also known as Fishtown, after the development of that name nearby. The delta is rather exposed to ocean winds, but is afforded some protection by the $01 y m p i c$ Peninsula and is lands in Puget Sound. Different groups have excavated these sites between 1959 and 1975, including the Washington Archeological Society, an association of amateurs .

A11 three sites are she 11 middens. One, $45 \mathrm{~kg} 9$, has both wet and dry portions. Fish remains made up the largest part of the faunal sample at all three sites. The Skagit River hosts the largest salmon runs of any river on Puget Sound. All five species of salmon were abundant in the faunal sample here. Deer and sea mammals were next in importance.

Hearths, post molds, and floors were encountered. Some burials were removed by local developers, but not recorded.

The disparities in procedures used at these three sites over time presents certain problems in getting a clear idea of what occupational activities these sites represent. 45 SK $33 B$ had a permanent structure and deep middens. It also contained one box-and-cairn burial and an isolated skull with 


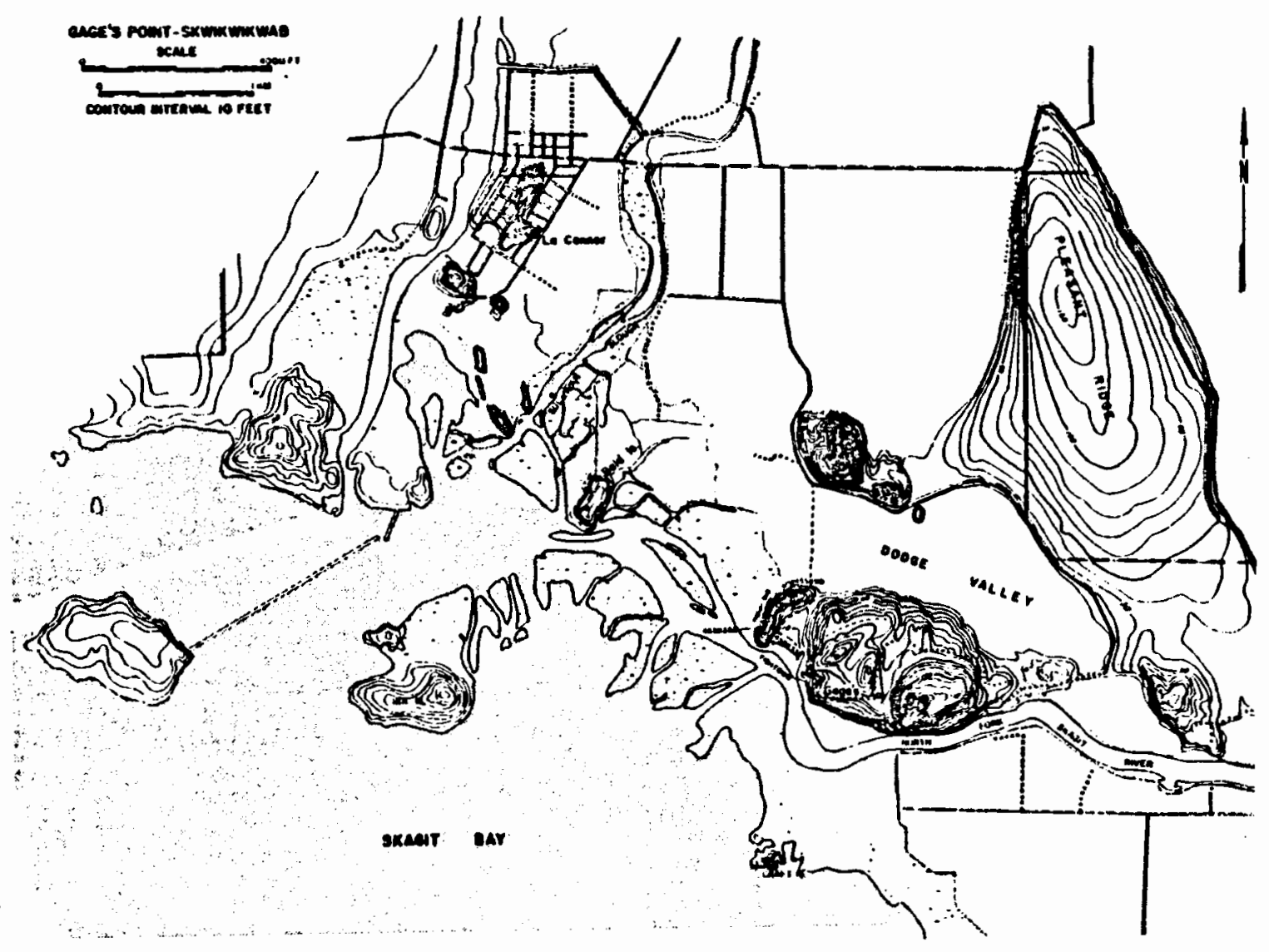

Figure 20. Skwikwikwab sites, 45Sk33A, 45SK33B, 45SK99, From Onat 1980. 


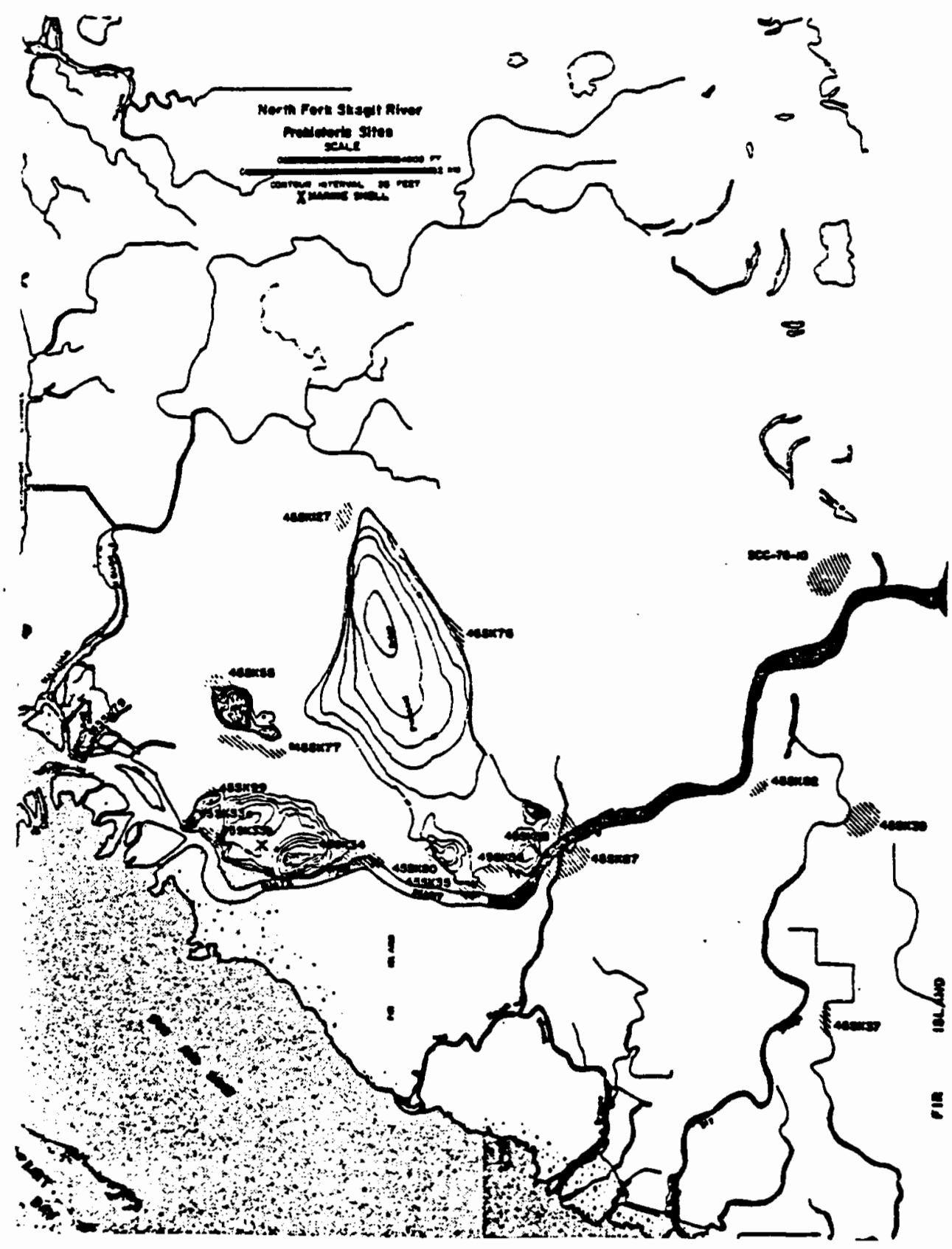

Figure 21. North Fork Skagit River archeological sites. From Onat 1980. 
evidence of decapitation and impalement. The remains of three individuals who were not interred, but lay in close association were also found here. 45 SK33A seems to be a resource processing area and an extension of 45SK33B. Many of the same kinds of tools and faunal remains are to be found at both sites, but no structures or other features were found at 45 SK33A. Onat interprets 45 SK99 to be yet another extension of the site grouping, used for initial procurement of $\mathrm{fish}$ and bird resources, and later as a cemetery. The matrices change from non-shell in the early component, to shell midden in the later levels. These sites are all Late Period occupations, beginning ca. 1,200 B.P. and ending about the time of contact. 


\section{CHAPTER I I}

\section{METHODS}

This study began with a desire to test the utility of looking at bone tool assemblages for information about subsistence activities at Northwest Coast shell midden sites. Patterns or regularities in the bone tool assemblages may represent "tool kits" which may reflect some aspects of subsistence practices. This stands in contrast to the usual practice of simply noting the presence or absence of certain bone tools and styles of bone tools. While it is certainly true that a complete understanding of a 11 subsistence activities practiced at a site, over time, cannot be gained simply by looking at bone tool kits, I believe that bone tool assemblages are a largely overlooked source of information about site usage.

In order to focus this analysis on the possible contribution from bone tool assemblages, I held other factors constant. I did not consider the stone tool assemblages, while it is known that this part of an archeological sample contributes much to an understanding of site usage. I also did not separate the bone tool assemblages from each site by component, nor did I lump sites together by time period. 
Shell midden sites on the Northwest Coast all represent Middle and Late Period occupations. Many of the sites considered here have an early, non-shell component, as well as a shell component. The bone tools recovered from the nonshell components account for a very small percentage of the bone tool assemblage from these sites. I chose to include the bone tools from the non-shell components, as they presumably represent the same or similar activities through time (see Ames 1976). This also gives me a slightly larger sample from each site, which is always helpful when using statistical procedures.

I held many ethnographic and environmental factors constant in this study, as we11. A clear and detailed assessment of prehistoric subsistence activities at a Northwest Coast she $11 \mathrm{midden}$ site requires an in-depth knowledge of regional and local variations in ethnographically known subsistence practices, as well as an intimate knowledge of micro-environmental factors, both current and prehistoric. The scope of the present study, which is exploratory in nature, precludes the fair consideration of all cf these factors. The reader is referred to the authors of the original site reports (Table I) for more information and bibliographies, and to Thompson 1978 for a good example of this kind of study using much more information. 
I had been working with the artifacts from the Prince Rupert Harbor sites and these seemed a good database for this kind of study. These sites were, and still are, undergoing analysis and so had little or nothing published about them. Boardwalk, Garden Island, and Grassy Bay were selected because of the differences in site size, assemblage size, and locations of the sites. Also, more analysis had been completed on these sites than others in the harbor.

Since analysis on these sites is incomplete, I decided to put them in the context of other sites in the region. I selected shell mounds as opposed to river canyon sites, because of the better preservation afforded bone by the shell matrix, but also to limit the range of adaptations under study. After reviewing published site reports of shell mounds in the Northwest Coast, I chose sites for which good descriptions and representations of the bone tool collections were available.

I had the opportunity to work directly with the Prince Rupert material as part of the Prince Rupert Artifact Analysis Project, under the direction of Dr. Kenneth Ames. We made the original measurements and attribute descriptions for a 11 of the Prince Rupert Harbor artifacts. It was at this point that the present study was initiated.

The form used for the description of the Prince Rupert Harbor bone, antler, and tooth artifacts is reproduced in the Appendix. I used these attributes to identify tools and fit 
them into the typology described below. The actual artifacts had been returned to the Museum of Man in Ontario at the time that I was constructing my typology. I mainly used Drucker's 1943 bone tool typology in its broad outlines (Drucker 1971), but also referred to Kidder (1932). The format of the Prince Rupert Harbor artifact database did not allow me to make stylistic determinations of the scale used in Drucker's system, but I was able to determine basic tool type.

The tool categories that I created for the Prince Rupert Harbor material are fixed bone points, bipoints, bone shanks, harpoon heads, rods, valves, awls, knives, wedges, incisor chisels, bark shredders, flakers, handles, tabular pieces, beads, canines, and ornamental. These are described in detail below. I then carefully examined the descriptions and illustrations of the bone tools from the other sites and put them into my own categories, using the same criteria that I had used for the Prince Rupert Harbor artifacts. It is clear that I needed very detailed descriptions of each of the artifacts, in order to match the typology as closely as possible between the Prince Rupert and other site assemblages. References for the original artifact inventories used to create these revised typologies are listed in Table I. My typology and those of the site report authors do not always coincide. Any errors in the assignation of tools to categories in this study are purely my own. 


\section{DESCRIPTIONS OF THE TOOL TYPES}

Fixed bone points are pointed objects with hafting elements, excluding only harpoon heads (see below). Point size was not a consideration in the present study. Haft fragments were included, but not tip fragments. I could not discern if tip fragments were from awls, bipoints, or fixed points, so I did not include them.

Bipoints are pointed at both ends. This includes all of the variations seen in this tool type. It may be that different kinds of bipoints were used for different objectives, but descriptive details of these small, simple tools are usually lacking in site reports.

Bone shanks are rare (see Figure 22). Shanks are a part of composite fish hooks. A small sharp barb is tied to one end of the shank and covered with pitch. The other end of the shank is tied to the fishing 1 ine. Ethnographically, this part of composite fish hooks were usually made of wood. It is likely that this was so in prehistory as well. A few sites did include shanks in their inventories, so I included the category here.

Harpoons (actually harpoon heads) are defined by their ability to detach from the shaft or foreshaft. Technically, "harpoons" consist of a shaft, a head, and sometimes a foreshaft. The archeological record nearly always contains only the harpoon head and foreshaft. In this study, harpoon 


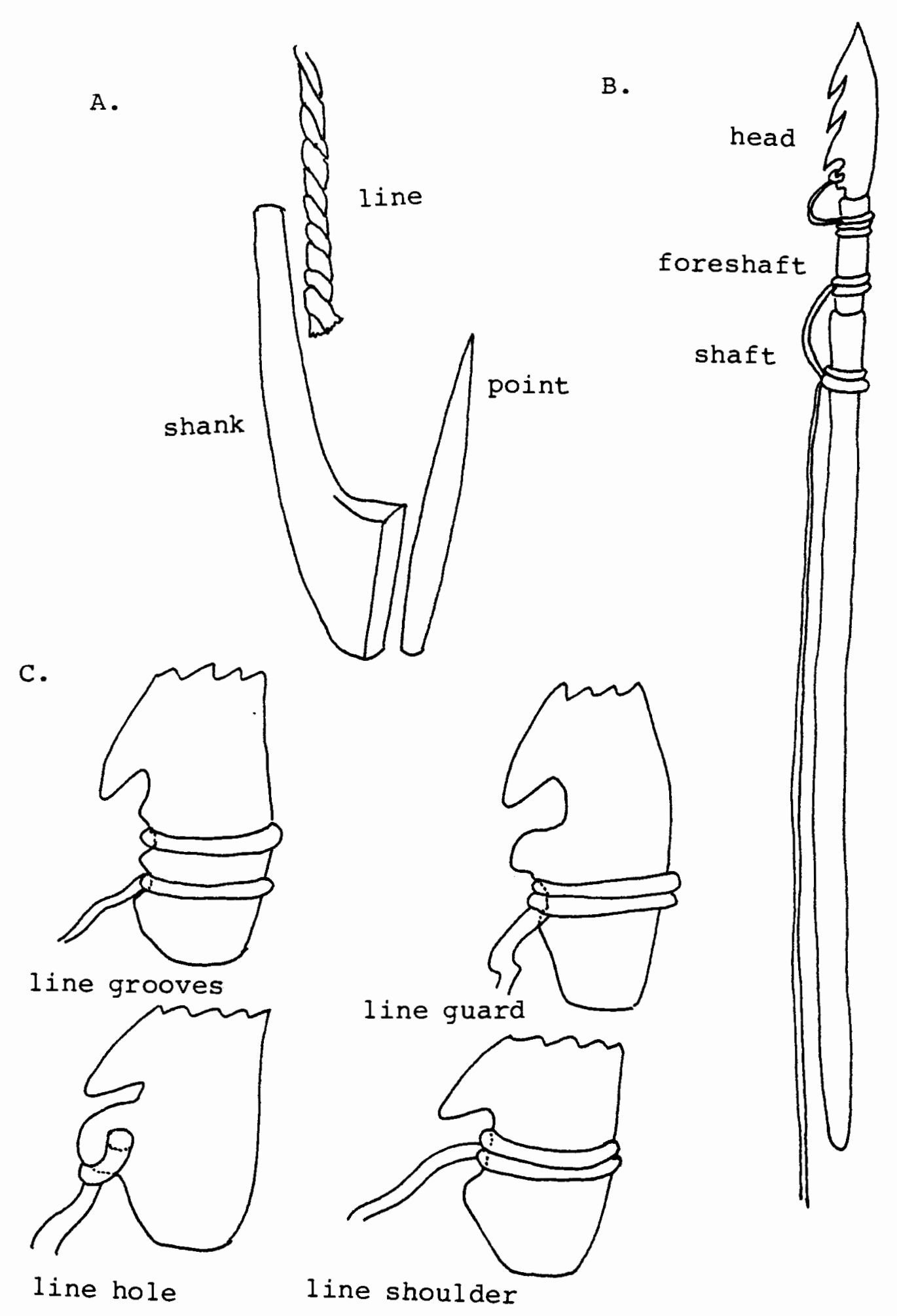

Figure 22. A. Composite fish hook B. 3-part harpoon assembly $C$. Methods of line attachment to harpoon head. 
heads will be referred to simply as "harpoons". The diagnostic portion of a harpoon (as opposed to a fixed, barbed point) is the line attachment. I labelled artifacts harpoons only if they had clear evidence of line attachment. This could be either a line hole, line guard, line grooves or well-defined line shoulder (see Figure 22). For this analysis, harpoons can be barbed or plain, or broken. But I only counted the basal elements with visible methods of line attachment. Tip fragments, even with high isolated barbs, were not counted in this category. This is a very conservative method of defining harpoons.

Rods are the usually cylindrical "shock absorbers" between the harpoon head and the shaft; they are usually called the foreshaft (see Figure 22). These artifacts were called "rods" in the Prince Rupert Harbor Artifact Analysis Project data files (following Drucker 1971, p. 55) and that usage is preserved here. Rods, or foreshafts, purposely break away from the head and shaft, preventing the tackle from being too damaged by the thrashing of the fish or sea mammal. Rods can be made of sea mammal bone, wood, or antler. They are roughly cylindrical or square in crosssection, parallel in plane view, or slightly tapering at one or both ends. Many presumably had hafting elements on one or both ends, but these are often broken or otherwise undiscernible. Where hafting elements are identifiable, it may be determined if the original harpoon head were male 
("harpoon"), or female ("toggling" harpoon). I did not use this subdivision with these data, because too many were broken, worn, or not clearly described. Some artifacts included in this category are complete, follow the general outlines for shape, but have no obvious hafting elements. Rods are not easily confused with anything else, except possibly handles (see below). It is also not clear that all rods were used as harpoon foreshafts; they may have been used for other purposes as well (Suttles, personal communication). Harpoon valves form the paired protruding sides on toggling composite harpoon heads (see figure 23). They are usually made of antler or bone. The possible variations were not considered here, as it was often impossible to determine if a valve had a channelled or scarfed distal end for arming, or if there were lashing channels around the exterior of the valve. The descriptions did not always include this information.

The category awls combines several of Drucker's original tool types. I also referred to Loy and Powell (1977) and Fladmark (1978) in defining this tool type. It contains Drucker's awls, awl-like forms, needles, gouges, and drills. Anything that is basically pointy, does not have a haft, and is not a tip fragment is here considered to be an awl. It may have been possible to break this down further by medium (bird bone, mammal bone), by method of manufacture, by size, or by possible use. But, assuming that all of these tools were 

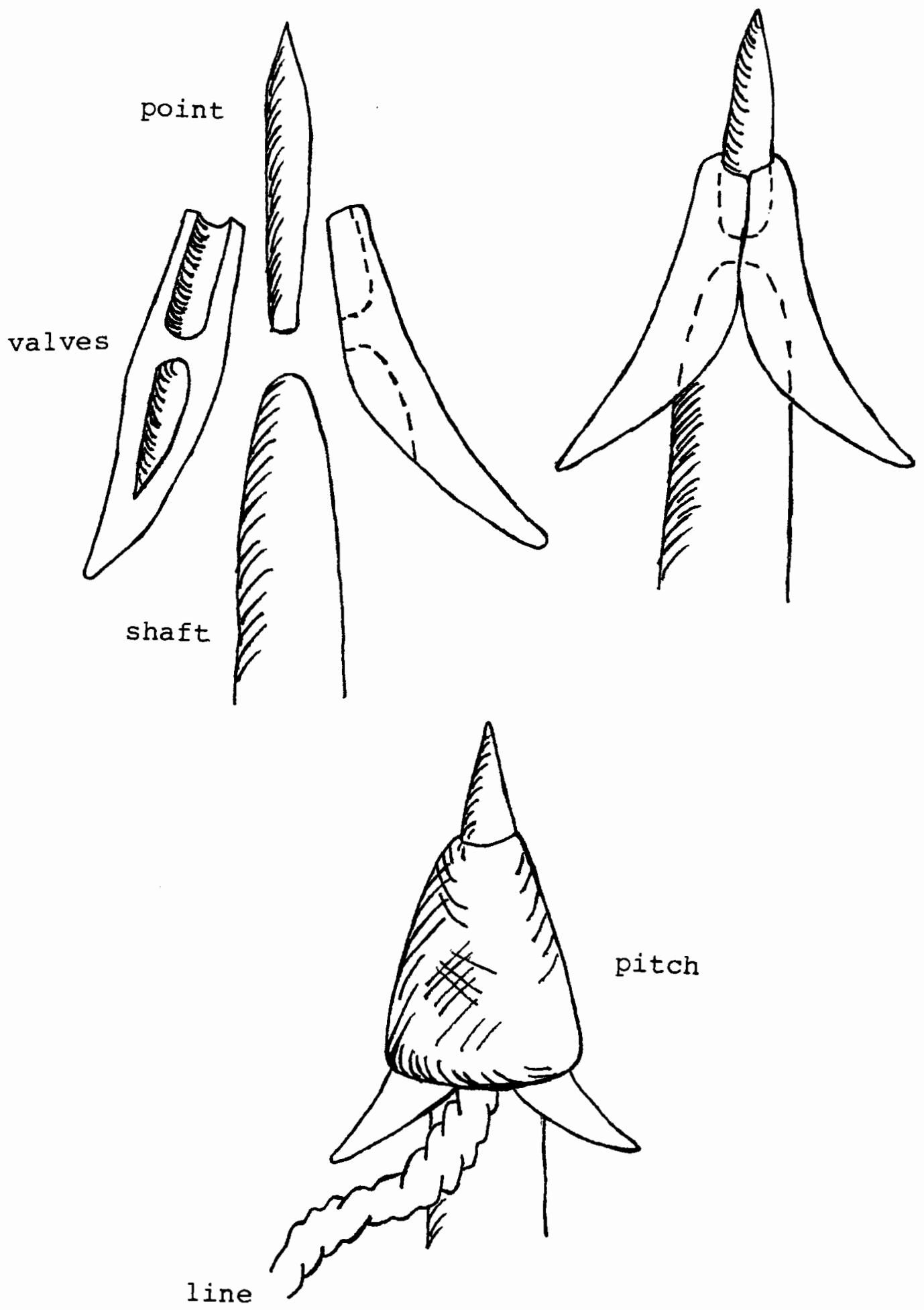

Eigure 23. Toggling harpoon assembly. 
used for piercing of some sort, I did not think that I had anything to gain by refining this category further. Many of the differences may be stylistic in nature, however I am not interested here in determining stylistic differences, but assemblage variation. Awls were used for piercing skins, wood, and bark sheets, and for coiled basketworking also (Matson 1976, p. 160; Murray 1982, p. 88; Mason 1901, p. 121; Kidder 1932, p. 203; Mitchel1 1971b, p. 184). Aw 1s appear in large numbers at some sites, probably due to their use patterns. Many are opportunistic tools, used only briefly and then discarded. They may also have had uses such as pinning mat houses together, and some awls may have been used to bait halibut trolling hooks (Suttles, personal communication).

Bone knives are long narrow tools which have a sharp working edge along one of the long sides. They are usually made from the ulnae of land mammals, but are occasionally made from ribs or split metapodials. Bone knives are very difficult to identify from published bone tool inventories because deer ulnae are often used in the Northwest to make both awls and knives. These two tools are often lumped together as "ulna tools" with descriptions which do not give details of the location of use wear or modification. I suspect that some may be hiding in faunal collections as we11. It may be that this tool type is slightly underrepresented in this study, but probably not to a 
significant degree, as they are never very numerous. Ethnographically, these tools were used primarily for processing fish, though they may also have been used for working plant fibers in baskets, mats, or clothing, for shaving cambium from tree bark, or for shredding soft inner bark (Drucker 1971, pp. 51-51).

Bone and antler wedges were used for certain aspects of woodworking. This category includes both antler wedges and bone wedges, including what might be called endscrapers elsewhere. Bone endscrapers were rarely mentioned in the bone tool inventories of the other sites here considered, but when they were, I put them in with the wedges for the sake of consistency. The defining factor for inclusion in this tool category is a wedge-shaped tip. Most bone and antler wedges found in archeological settings are broken. Many, but not al1, authors catalogue the butt end of broken wedges as wedges. These proximal ends of wedges were not clearly defined in the Prince Rupert Harbor artifact database, so I did not include these fragments in this study.

Incisor chisels are beaver or porcupine incisors which have been collected and modified for use, or by use. They were probably hafted in wooden handles, though only the chisels remain. They were occasionally split longitudinally, polished on the cut side and used. It is assumed that these tools were used for fine wood carving. This is another tool type which is may not always be recognized. 
Bark shredders (also called bark beaters--Niblack 1970, p. 312) made of sea mammal bone are exceedingly rare in Northwest Coast archeological deposits. "Shredders" (as I will call them in this study) are of one piece, with a handle leading to a large rectangular "mallet". This "mallet" has longitudinally carved $v$-shaped ridges on the working side. The tool was wielded rather like a hammer, pounding bark fibers with the ridged face of the shredder. Due to the size and shape of the tool, it can only be made of sea mammal bone or stone. Large pieces of sea mammal bone are not easily obtained and were probably not often discarded. Broken pieces of sea mammal bone bark shredders would be very difficult to recognize in the midden, as sea mammal bone looses its edges in shell midden. Nevertheless, a few shredders were reported in this data set, so the category is included.

The pointed tines of deer antler were used for pressure flaking obsidian and other siliceous stone (Fladmark 1978, pp. 152, 155; Mitchel1 1971b, pp. 141, 210; Drucker 1971, p. 54). Antler flakers are probably also hidden in some of the tool inventories as "antler fragments" or in faunal collections. In some areas, including Prince Rupert Harbor, little or no stone flaking was done. Where flakers were identified or could be determined from descriptions, they were included. 
Handles for composite tools were made of wood, bone, or antler. Recognizable bone or antler handles are rather unusual in Northwest Coast deposits. It is likely that wood was preferred and has not been preserved.

The category "pendant" contains all decorative items which could have been suspended. These may have been worn on necklaces or bracelets, may have been sewn to clothing, or tied to rattles or headdresses. This includes various teeth and claws which were girdled or pierced for suspension, as well as carved bone or antler pendants.

Iabular pieces are flat, usually angular pieces of bone which were used to decorate clothes, hats, and boxes and were also worn suspended. They are very rare finds and very difficult to identify.

Beads are almost anything so described. I also created a category of bird bone tubes, which I did not ultimately use in the analysis (see below). However, anything that was "long" and finished on the ends was considered a tube. There seemed to be natural break in the data at about 3 or $4 \mathrm{~cm}$. I considered the items shorter than $3-4 \mathrm{~cm}$. as beads and those longer as tubes.

Canines includes the few canines that were not clearly identifiable as pendants and "ornamental" includes pieces of browbands, bone rings, elaborately carved bone blanket pin heads, and bone labrets. Plain or minimally decorated blanket pins were not included, for reasons detailed below. 
In sum, eighteen artifact categories were used in the comparisons. A cluster analysis, described below, was run on a matrix of the eighteen categories and the fifteen sites. Artifact categories were then combined into three functionally-based groups and a cluster analysis run again. The three groups were designated "procurement", "modification" and "ornamental". Procurement is comprised of the figures for fixed bone points, bipoints, shanks, harpoons, rods, and valves. Modification contains awls, knives, incisor chisels, shredders, flakers, and handles. Ornamental includes pendants, tabular pieces, beads, canines, and ornamental items.

These three groups represent the presumed uses of the tools. Procurement tools are those used for the primary procurement of resources. Modification tools are those used for the processing of resources, and manufacture and repair. Ornamental objects are presumed to have importance in the social structure and are not immediately involved in the procurement or modification of resources. However, the social structure, represented on ly vaguely by the remains of ornamental items, organized access to resources.

Combining the eighteen tool types into three general groups demanded the elimination of a few tool types which did not fit clearly into any of the groups. Bird bone tubes was one of these. Bone tubes were evidently used for drinking water not only during periods of ritual cleanliness, but also 
during canoe trips, when water was carried in covered containers. Tubes, then, are not involved strictly in procurement or processing, nor were they used strictly for ceremonial or social uses. Plain or only lightly decorated blanket pins are also ambiguous. They seem to be simply an item of daily use which could not be put into any of the three general groups. It is for this reason that blanket pins were not included.

\section{CLUSTER ANALYSIS}

Cluster analysis was chosen as the statistical procedure. Similarity was measured by Euclidean distance, average linkage was used, and the computer program was Systat's cluster module (wilkinson, 1987). Cluster analysis seeks patterns in very complex data and so is perfectly suited to investigations which are exploratory in nature. It is also a method for creating typologies (Shennan 1988; Aldenderfer and Blashfield 1984, p. 9). Basically, clustering procedures consider all of the variables measured for each of the cases (here the variables are the tool types and cases are sites) and then mathematically determine the degree of similarity between cases. Cases which meet a specified degree of similarity are grouped together to form a cluster. The procedure should produce clusters of cases which are most similar. 
After the sample had been selected and the variables defined and measured, a matrix was constructed of rows of $\mathrm{N}$ cases (the sites) by columns of $P$ variables (the artifact classes). At this point, the data were standardized by transforming the raw figures into percentages. The row totals therefore added up to 100 for al1 cases (sites). A calculation of similarity was then performed on these figures.

There are four different measures of similarity, or "similarity coefficients" which can be used for cluster analysis (Aldenderfer and Blashfield 1984, p.17). Two of them require binary data, which these data clearly are not. Correlation coefficients can also be used to measure similarity. However, correlation coefficients on ly measure covariance, and are insensitive to the scale of the variances. In this study, the scale of variance is as important as the incidence of covariance.

Distance measures can also be used to measure similarity. These have great intuitive appeal. The more similar two data points are, the closer together they are. This distance can be measured in several ways. The most commonly used method is Euclidean distance. The points are plotted on an $x-y$ grid and the Pythagorean Theorem is used to calculate the straight line distance between them. Basically, these distance values are added together for cases with more than one variable (Shennan 1988, pp. 199-200). 
The problem with using Euclidean distance in this manner is that it assumes that the variables are totally independent of one another. This is never the case in reality. The distance measure may be over-or under-estimated, to a degree determined by the intercorrelation of the variables. In cluster analysis, this may exaggerate or diminish the distance between clusters, but it should not create clusters which do not exist in the data.

After similarity has been measured for all variables of each case (site), these are combined to produce a single similarity coefficient for each site. An $N$ by $N$ matrix is constructed of these coefficients and a method of cluster analysis used to create groups of similar entities ("clusters"). Aldenderfer and Blashfield (1984, p. 35) present seven major families of cluster analysis methods. The most frequently used methods are the hierarchical agglomerative methods.

There are three kinds of hierarchical agglomerative clustering methods; single, complete and average 1 inkage. All three search the $N$ by $N$ similarity matrix and sequentially join the most similar cases (sites). They are agglomerative in that they join cases and hierarchical in that they progress from the most similar to the least similar cases.

Single linkage cluster analysis joins cases one by one to an existing cluster, with the result that a single cluster 
is ultimately formed of all cases. Each case is required only to be similar to a single case in the existing cluster. The opposite extreme, complete linkage, requires that each new member achieve a set level of similarity to all of the others members of an existing cluster. This method tends to form two, very distinct clusters. Unfortunately, these do not always reflect known patterns in the data (Aldenderfer and Blashfield 1984, p. 40).

Average 1 inkage, the method used in the present study, first calculates a coefficient equal to the average of the similarity coefficients of all of the members of an existing cluster. New members must then achieve a predetermined level of similarity to that group average. This method avoids the pitfalls of both single and complete linkage.

In this way, groups of similar entities are formed. Dendrograms can then be generated to graphically portray these relationships. The final step in cluster analysis is validation of the cluster solution. A weakness of hierarchical agglomerative methods is that they may form unstable clusters. That is, if the data are shuffled and entered in a different order, different clusters may be formed. Also, dropping one or more cases from the data set can change the resulting cluster solution. I tested the stability of the cluster solutions achieved in this study by first rearranging the entry order of the data. This reordered data entry produced identical cluster solutions. I 
then deleted one case (Yakutat Bay) and performed the cluster analysis again. This also produced identical solutions (minus Yakutat Bay, of course). These tests demonstrate that the clusters formed in these procedures are very stable. This is considered good evidence that these clusters have general utility (Aldenderfer and Blashfield 1984, p. 65). 
CHAPTER IV

\section{ANALYSIS}

The dendrograms for the combined class and the individual tool type matrices have many similarities (see Figures 24 and 25 ). Cluster 1 of the combined class dendrogram contains the same sites as the individual tool type cluster 2, except that in the 1 atter, Duke Point has replaced Skwikwikwab, and Grant Anchorage has been added.

Cluster 2 of the combined class tree looks much like cluster 1 of the individual tool type arrangement. O'Connor, Hesquiat, and Little Qualicum remain together, and TN1, 023, and Georgeson Bay also stay together. Shoemaker Bay moves slightly from a direct association with Georgeson Bay in the combined class tree, to a direct association with Belcarra Park in the individual tool type tree.

Eleven of the fifteen sites considered remained in stable clusters - a $73 \%$ concordance between the two procedures.

Organizing the data into three functional tool groups highlights clear differences and similarities among the sites (see Table II). Cluster 1 sites have the lowest overall percentages of procurement tools, and the highest percentages of resource modification tools. Cluster 2 sites show a tool- 
0.000 DISTANCES 10.000

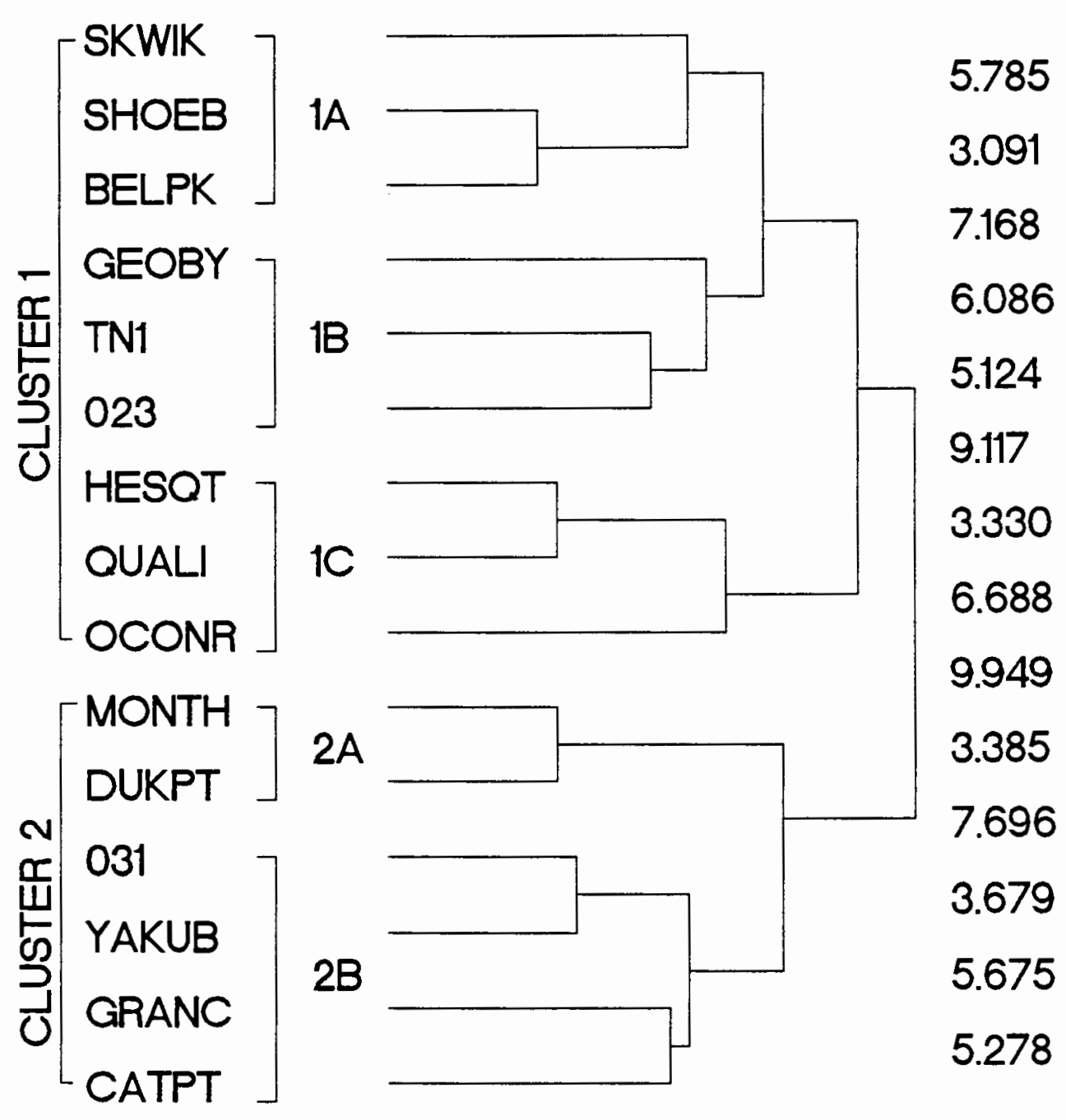

Figure 24. Combined class cluster analysis dendrogram. 


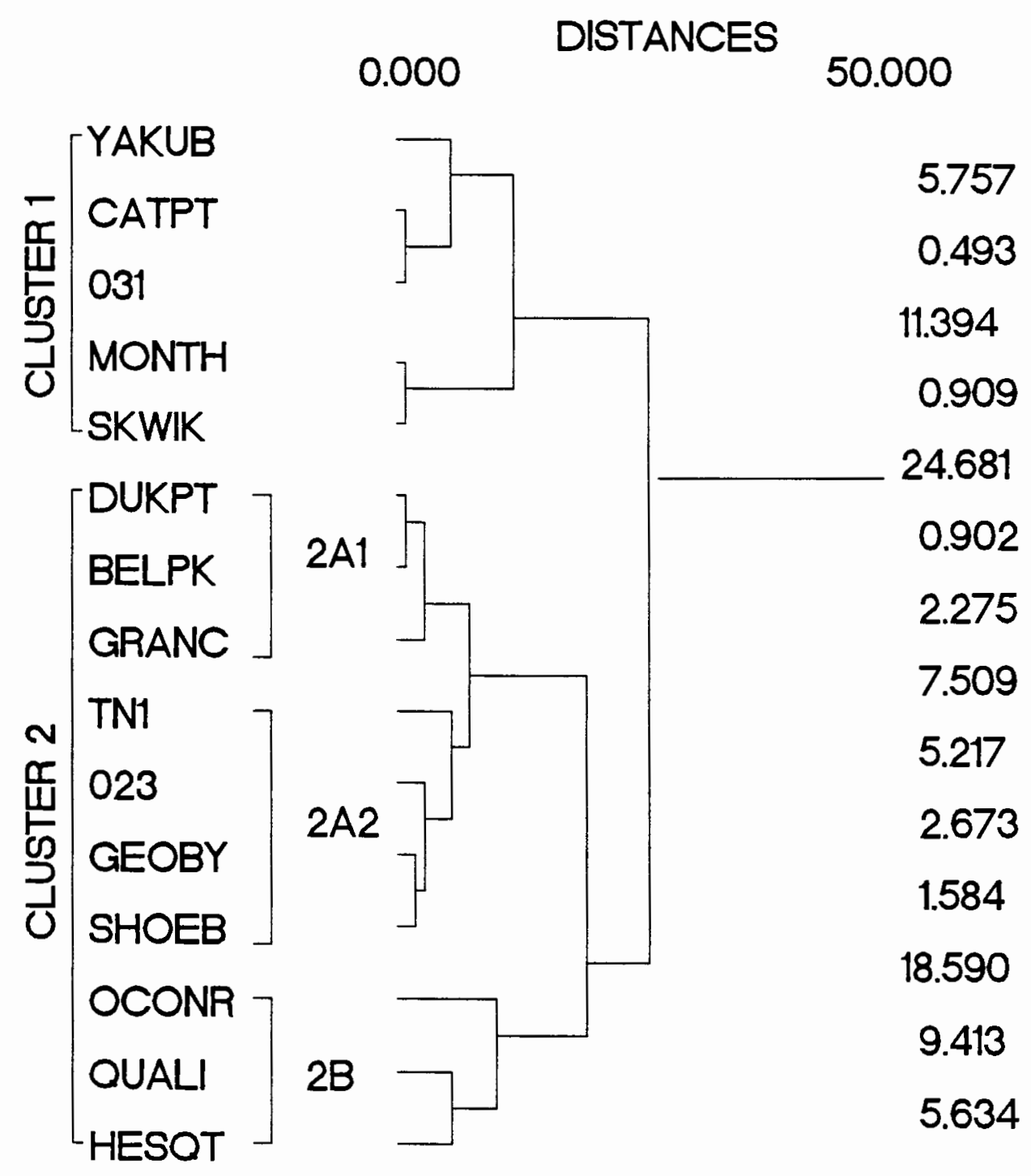

Figure 25. Individual tool type cluster analysis dendrogram. 
type shift among the sub-clusters seen as a rise in procurement tool frequencies and a fall in modification tool frequencies from $2 a 1$ through $2 b$. The on $1 y$ pattern among the ornamental material is that 2 b sites have extremely low percentages of these artifacts.

TABLE II

RAW DATA ORGANIZED INTO COMB INED CLASS CLUSTERS

(FIGURES IN PARENTHESES ARE PERCENT OF TOTAL)

\begin{tabular}{|c|c|c|c|c|}
\hline $\begin{array}{l}\text { PROCURE } \\
\text { MODIF } \\
\text { ORNAM } \\
\text { TOTAL }\end{array}$ & $\begin{array}{l}\frac{\text { MONTH }}{126(48.1)} \\
123(50.1) \\
\frac{5(2)}{262}\end{array}$ & $\begin{array}{l}\text { SKWIK } \\
\frac{\text { CLU }}{269(47.1)} \\
293(51.3) \\
\frac{10(1.8)}{572}\end{array}$ & $\begin{array}{l}\text { TER 1 } \\
\frac{031}{532}(32.4) \\
1048(63.8) \\
\frac{63(3.8)}{1643}\end{array}$ & $\begin{array}{l}\frac{\text { CATPT }}{94(31.8)} \\
189(63.9 \\
\frac{13(4.4)}{296}\end{array}$ \\
\hline $\begin{array}{l}\text { PROCURE } \\
\text { MODIF } \\
\text { ORNAM } \\
\text { TOTAL }\end{array}$ & $\begin{array}{l}\frac{\text { GRANT }}{164(55.3)} \\
118(39.9) \\
\frac{14(4.8)}{293}\end{array}$ & $\begin{array}{l}{ }_{\text {DUKE }}^{\text {CLUS }} \\
\frac{36(58)}{24(38.7)} \\
\frac{2(3.2)}{62}\end{array}$ & $\begin{array}{l}\text { TER 2A1 } \\
\text { BELPK } \\
291(58.8) \\
197(39.3) \\
\frac{10(2)}{515}\end{array}$ & \\
\hline $\begin{array}{l}\text { PROCURE } \\
\text { MODIF } \\
\text { ORNAM } \\
\text { TOTAL }\end{array}$ & $\begin{array}{l}\frac{023}{399(64.5)} \\
180(29) \\
\frac{39(6.3)}{618}\end{array}$ & $\begin{array}{l}\text { CLUS } \\
\frac{\text { GEOBY }}{54(68.4)} \\
22(27.9) \\
\frac{3(3.8)}{79}\end{array}$ & $\begin{array}{l}\text { TER } 2 \text { A2 } \\
\text { SHOEBY } \\
\frac{363(67.1)}{163(30.1)} \\
\frac{15(2.8)}{541}\end{array}$ & $\begin{array}{l}\frac{T N 1}{41(59.5)} \\
22(31.9) \\
\frac{6(8.8)}{69}\end{array}$ \\
\hline $\begin{array}{l}\text { PROCURE } \\
\text { MODIF } \\
\text { ORNAM } \\
\text { TOTAL }\end{array}$ & $\begin{array}{l}\frac{\text { OCONR }}{175(78.2)} \\
47(21) \\
\frac{2(0.9)}{224}\end{array}$ & $\begin{array}{l}\text { CLUS } \\
\frac{\text { QUALI }}{45(86.7)} \\
7(13.4) \\
\frac{0(0)}{52}\end{array}$ & $\begin{array}{l}\text { TER 2B } \\
\text { HE SOT } \\
\frac{73(93.6)}{5(6.5)} \\
\frac{0(0)}{78}\end{array}$ & \\
\hline
\end{tabular}

Tables III - VII contain site-specific numbers and frequencies of the eighteen individual tool types based on raw data obtained from the excavation reports cited in Table 
I. The following discussion will center on the information presented in these Tables III-VII. Individual tool type cluster analyses will be the focus of this discussion.

Cluster 1 contains sites in which procurement tools constitute more than $50 \%$ of the assemblage. There is also interesting variation within the cluster which may reflect differences in the subsistence activities followed at each site.

Shoemaker Bay, Belcarra Park, and Skwikwikwab are associated in Cluster 1a (see Table III). All three contain bone tool kits of fixed bone points, valves, and awls. Fixed points account for the largest part of each assemblage. At Shoemaker Bay and Belcarra Park, no other tool types are dominant. At Skwikwikwab, wedges and, to a lesser degree, flakers, are also important components of the assemblage. In fact, the high percentage of wedges at Skwikwikwab is responsible for its place in the resource modification cluster in the combined class tree.

These three sites share the fixed point-valve-awl tool kit which probably represents subsistence activities centered around salmon fishing. Fixed points and valves were used for taking the fish with single or two pronged harpoons, armed with small detachable composite toggle heads. Awls, in their variety of shapes and sizes, were probably used for a number of resource modification activities. This subcluster contains the highest percentages of awls in cluster 1 . 
TABLE II I

RAW DATA ORGANIZED INTO

INDIVIDUAL TOOL CLASS CLUSTERS - CLUSTER 1 A

(FIGURES IN PARENTHESES ARE PERCENT OF TOTAL)

$\begin{array}{llll} & \text { SHOEB } & \text { BELPK } & \text { SKWIK } \\ \text { FIXED PT } & 242(44.7) & 185(36) & 171(29.9) \\ \text { BIPT } & 12(2.2) & 9(1.8) & 21(3.7) \\ \text { SHANK } & 7(1.3) & 0(0) & 0(0) \\ \text { HARPOON } & 2(0.4) & 10(2) & 1(0.2) \\ \text { ROD } & 8(1.5) & 3(0.6) & 0(0) \\ \text { VALVE } & 92(17) & 94(18.4) & 76(13.3) \\ \text { AWL } & 118(21.8) & 154(30.1) & 92(16.1) \\ \text { KNIFE } & 7(1.3) & 0(0) & 24(4.2) \\ \text { WEDGE } & 19(3.5) & 20(3.9) & 117(20.5) \\ \text { INCISOR } & & & \\ \text { CHISEL } & 7(1.3) & 23(4.5) & 20(3.5) \\ \text { SHREDDER } & 1(0.2) & 0(0) & 0(0) \\ \text { FLAKER } & 11(2) & 0(0) & 37(6.5) \\ \text { HANDLE } & 0(0) & 4(0.8) & 3(0.5) \\ \text { PENDANT } & 0(0) & 0(0) & 2(0.4) \\ \text { TABULAR } & 0(0) & 0(0) & 0(0) \\ \text { BEAD } & 1(0.2) & 3(0.6) & 3(0.5) \\ \text { CANINE } & 14(2.6) & 4(0.8) & 1(0.2) \\ \text { ORNAM } & \frac{0(0)}{541} & \frac{3(0.6)}{515} & \frac{4(0.7)}{572} \\ \text { TOTAL } & & 515 & \end{array}$

The percentages of wedges and flakers at Skwikwikwab are among the highest for these tools of any of the sites studied here. Floors, hearths, post molds, and burials were encountered during excavations at the site. Features such as these are usually considered evidence of a "winter village" site. The Skagit River boasts the largest salmon runs in Puget Sound (Onat 1980,p.193). All five species of salmon run there, extending the salmon season from early May to late January. Faunal analysis led Onat to conclude that fish was the most important food source, with deer and sea mammals also accounting for much of the sample. Unfortunately, fish 
remains were not identified as to species. Skwikwikwab was probably a major salmon camp or village, with permanent structures used for long periods each year. Wedges were likely used to construct or replace elements of the structures as well as repairing or replacing the many wooden implements used in fishing, hunting, and daily life.

Shoemaker Bay lies at the mouth of the Somass River with its very productive salmon runs. The Somass River opens onto Alberni Inlet. This inlet derives from Barkley Sound on Vancouver Island's west coast. All five salmon species run here, from late summer through the winter. While there are numerous sites along the banks of the Somass, Shoemaker Bay is the only known site laying just at the river's mouth.

The faunal collection from this site is interesting, because it includes species which must have been acquired from distant Barkley Sound (such as California Mussel, see Quayle 1960, p. 24)), or from high alpine environments, such as marmot (MCMillan and St. Claire 1982). Herring were also in the sample, accounting for $39 \%$ of identifiable fish remains in the later component. Herring spawn in Alberni Inlet in the spring but probably do not come very near the mouth of the river due to their preference for more saline water.

Given the preponderance of fixed points and valves in the bone tool kit, it seems that salmon fishing was an important activity at the site. $48 \%$ to $71 \%$ of identifiable 
fish remains were salmon, depending on component. Situated at the mouth of the river, site occupants also had access to resources obtained in more remote locations and perhaps at other times of year, as evidenced by the exotic faunal remains.

Finally, Belcarra Park boasts the largest percentage of harpoon valves at any of the sites considered here. It lies at the juncture of Indian Arm and Burrard Inlet, just north of the Fraser River. The faunal analysis had not been completed when Charlton wrote the site report (1980). Evidently, the sample contains mostly fish and indicates a late fall and winter occupation. The site is generally considered to be a winter village site and the bone tool kit suggests a heavy emphasis on fishing with small composite toggling points. Salmon which could be caught with these harpoons are found in Indian Arm.

The three cluster 1 a sites, with their high numbers of fixed bone points and valves, all contain large numbers of salmon in their faunal samples, or are closely associated with streams hosting large salmon runs. The fixed bone points and valves probably are the remains of toggling harpoons used for salmon fishing.

Cluster 1b contains TN1, 023, and Georgeson Bay (see Table IV). The unifying element in this sub-cluster is a high percentage of fixed bone points and low percentages of everything else, except pendants. 
TN1 has a rather unusual bone tool assemblage. There is a high percentage of harpoons (relative to numbers for this tool type at the other sites), the highest percentage of rods, and very low percentage of valves. The harpoon-rod combination suggests sea mammal hunting, and, indeed, the faunal sample is dominated by harbor seals (Hull 1980). The water at Grassy Bay is very shallow and contains much kelp, which attracts small fish for seals to eat. There are also five tiny "islands" in the bay, which are probably good hauling-out spots for seals. Rhinoceros auklets were also important in the sample.

\section{TABLE IV}

RAW DATA ORGANIZED INTO

INDIVIDUAL TOOL CLUSTERS - CLUSTER 1B (FIGURES IN PARENTHESES ARE PERCENT OF TOTAL)

$\begin{array}{llll}\text { FIXED PT } & \frac{\text { TN1 }}{27(39.1)} & \frac{\mathbf{0 2 3}}{316(51.1)} & \frac{\text { GEOBY }}{50(63.3)} \\ \text { BIPT } & 2(2.9) & 65(10.5) & 0(0) \\ \text { SHANK } & 0(0) & 0(0) & 0(0) \\ \text { HARPOON } & 3(4.4) & 8(1.3) & 1(1.3) \\ \text { ROD } & 8(11.6) & 10(1.6) & 0(0) \\ \text { VALVE } & 1(1.5) & 0(0) & 3(3.8) \\ \text { AWL } & 9(13) & 44(7.1) & 11(13.9) \\ \text { KNIFE } & 1(1.5) & 70(11.3) & 0(0) \\ \text { WEDGE } & 4(5.8) & 19(3.1) & 7(8.9) \\ \text { INCISOR } & & & \\ \text { CHISEL } & 6(8.7) & 38(6.1) & 1(1.3) \\ \text { SHREDDER } & 0(0) & 0(0) & 0(0) \\ \text { FLAKER } & 2(2.9) & 7(1.1) & 2(2.5) \\ \text { HANDLE } & 0(0) & 2(0.3) & 1(1.3) \\ \text { PENDANT } & 3(4.4) & 16(2.6) & 2(2.5) \\ \text { TABULAR } & 0(0) & 5(0.8) & 0(0) \\ \text { BEAD } & 0(0) & 4(0.7) & 0(0) \\ \text { CANINE } & 3(4.4) & 12(1.9) & 0(0) \\ \text { ORNAM } & 0(0) & 2(0.3) & 1(1.3) \\ \text { IOTAL } & 69 & 618 & 79\end{array}$


The east coast of Kaien Is land, where TN1 is located, is dotted with medium to large shell mounds (Archer 1977, pp. 77-93). It is very likely that this small site was a special use site for sealing and birding.

023, or Garden Is Iand, has a very high percentage of fixed bone points, second only to Georgeson Bay. It also has the highest percentage of knives of any of the assemblages considered here. 023 is a small site, on a very small island in shallow waters with a large kelp bed. Faunal analysis has not been done for this site, but characteristics of the environment and the bone tool assemblage suggest that 023 was used in part for catching herring.

Prince Rupert Harbor presently supports a population of herring. The area of Garden Is land is a favorite location for herring (Hoos 1975, p. 87). Herring like kelp beds for spawning and as a place to wait before spawning. While they wait, they do not eat but burn stored fat. For taking the fish, not the spawn, it is better to take them as soon as they come into the kelp beds.

The emphasis on fixed bone points in the assemblage probably represents the use of herring rakes for harvesting the fish. The high percentage of knives at the site probably indicates processing of the fish at the site. Incisor chisels, present in rather high numbers, may have been used for carving holes in wooden fish rakes. Thus, it seems 
reasonable that catching herring was an important activity at Garden Is land.

Georgeson Bay contains the highest percentage of fixed bone points of all fifteen sites. Awls make up the only other tool type of any importance in this assemblage. Unfortunately, this assemblage represents a very small sample of a very large shell midden. For this reason, any reconstruction of site use is preliminary at this point. Environmental characteristics and the nature of the recovered bone tool assemblage permit some observations, however. Georgeson Bay is located at the western entrance to Active Pass on Galiano Island in the Gulf of Georgia. This is just opposite the Pass from Helen Point. The Georgeson Bay site is at least as large as the site at Helen Point. Sockeye salmon go through Active Pass in great numbers on their way to the Fraser River.

Both a kelp bed and a large reef lay just offshore of the site. Harbor seals haul out on this reef. Seals prey on herring, which winter in kelp beds.

Fixed bone points may account for such a high percentage of the recovered sample because herring fishing was an activity at Georgeson Bay. Faunal remains are mainly deer, dog, and harbor seal but also salmon and other fish, including herring found in soil samples. The remains of harbor seals indicate that sealing was also an activity at the site. Ethnographically, reef-net fishing pink and 
sockeye salmon was the major activity at Active Pass in the summer, while halibut, chinook, and coho were probably fished with hook-and-line in the spring (Suttles, pers. comm.). This latter kind of fishing would account for the high percentage of fixed points. Perhaps future excavations at the site will clarify the situation.

The three Cluster $1 \mathrm{~b}$ sites all have very 1 arge percentages of fixed bone points. Faunal samples and environmental considerations suggest that these are all special use sites, used for resource procurement. TN1 was probably used for hunting seals, 023 for fishing herring, and Georgeson Bay for herring, seals and probably halibut and salmon as well (see the site description for the ethnographic references of halibut and salmon fishing in Active Pass, which also would have utilized bone points in hooks).

Cluster $1 \mathrm{c}$ contains Hesquiat, Little Qualicum, and o'Connor (see Table $V$ ), each with a tool kit emphasizing fixed points and bipoints, nearly to the exclusion of any other tool types.

Hesquiat is a medium-sized shell midden which sits on a low bluff at the entrance to Hesquiat Harbor on the west coast of Vancouver Island. Faunal analysis indicates occupation during all seasons. Fish dominate the faunal sample, but these are rockfish, greenling, and 1 ing cod, rather than salmon. Sea mammals far outnumber land mammals and account for the bulk of edible protein represented by the 
sample. Seals are especially numerous, but sea otters are also important. Dolphins and whales are also present. Bird remains were very numerous at the site, albatross being the most common species.

\section{TABLE V}

RAW DATA ORGANIZED INTO

INDIVIDUAL TOOL CLUSTERS - CLUSTER 1C (FIGURES IN PARENTHESES ARE PERCENT OF TOTAL)

$\begin{array}{llll}\text { FIXED PT } & \frac{\text { HESOT }}{39(50)} & \frac{\text { OUALI }}{27(30.8)} & \frac{\text { OCONR }}{73(32.6)} \\ \text { BIPT } & 22(28.2) & 16(52) & 92(41.1) \\ \text { SHANK } & 0(0) & 0(0) & 0(0) \\ \text { HARPOON } & 0(0) & 0(0) & 10(4.5) \\ \text { ROD } & 0(0) & 0(0) & 0(0) \\ \text { VALVE } & 12(15.4) & 2(3.9) & 0(0) \\ \text { AWL } & 2(2.6) & 5(9.6) & 43(19.2) \\ \text { KNIFE } & 0(0) & 0(0) & 0(0) \\ \text { WEDGE } & 3(3.9) & 1(1.9) & 0(0) \\ \text { INCISOR } & & 1(1.9) & 4(1.8) \\ \text { CHISEL } & 0(0) & 0(0) & 0(0) \\ \text { SHREDDER } & 0(0) & 0(0) & 0(0) \\ \text { FLAKER } & 0(0) & 0(0) & 0(0) \\ \text { HANDLE } & 0(0) & 0(0) & 2(0.9) \\ \text { PENDANT } & 0(0) & 0(0) & 0(0) \\ \text { TABULAR } & 0(0) & 0(0) & 0(0) \\ \text { BEAD } & 0(0) & 0(0) & 0(0) \\ \text { CANINE } & 0(0) & 0(0) & 0(0) \\ \text { ORNAM } & 0(0) & 52 & 224 \\ \text { TOTAL } & 78 & & \end{array}$

The bone tool assemblage at Hesquiat is dominated by fixed bone points. Next in importance are bipoints and then valves. The percentage of valves is quite high, compared to the other sites. Fixed points and valves might indicate sea mammal hunting. If so, however, the absence of harpoons and rods is puzzling. Perhaps fixed points were used for hook- 
and-line fishing for rockfish, greenling, and cod. Multiple bipoints were used on fixed lines to catch bottomfish (Stewart 1977, p. 45) and for catching birds (Mitchel1 1971b, p. 150; de Laguna 1972, p. 373).

The bone tool assemblage at Hesquiat does not contain the diversity of equipment needed to maintain a year round, permanent occupation. Also, the site is rather exposed. Deeper inside the harbor, where it is more protected from the elements, would be a better location for a winter village. For these reasons, Hesquiat was probably used as a base of operations for ocean fishing, birding, and sea mammal hunting for short periods during the year.

The Little Qualicum site is at the delta of the Little Qualicum River where it enters the Strait of Georgia, on the east coast of Vancouver Island. One of the largest chum runs in this area occurs on the Little Qualicum. Tidal and river weirs were found near the site. Salmon accounts for most of the faunal material at the site, but herring was also important. Herring probably came into the little bay near the site in the fall and winter, waiting to spawn in spring. Ducks and geese were also among the faunal remains. Small post holes and ash lenses were found at the site, probably representing fish drying racks and temporary structures.

Little Qualicum was clearly a salmon-and-herring site. The bone tool assemblage contains almost nothing other than fixed points for hooking salmon and for rakes, a few valves, 
and bipoints, also used for hooking fish and for catching the water birds which probably stopped by the delta on their migrations. Ethnographically, baited bipoints were used, as wel1 as nets and arrows, for catching waterfow 1 .

The O'Connor site is situated on an estuary formed by the meeting of the Quatse and other rivers into Hardy Bay on the northeast coast of Vancouver Island. Salmon run in the Quatse and other nearby streams from April to November. Faunal remains at this site are mostly salmon bones. No evidence of large structures was found.

The Bone tool kit from 0 'Connor is dominated by bipoints and fixed points, but a little less so than the other two sites in this sub-cluster. Awls and harpoons are also present in fairly high percentages. This site also has a much larger sample than the other two in this sub-cluster. Certainly salmon fishing was an important activity at this site.

Cluster 1c sites all have bone tool kits made up almost exclusively of fixed bone points and bipoints. Little Qualicum and $0^{\prime}$ Connor are located on estuaries, and show evidence of short term occupation with fishing and birding the main subsistence activities. Hesquiat also appears to be a site used for short term resource procurement activities, also mainly fishing and birding. 
Cluster 2 contains two sub-clusters. 2 a includes Montague Harbor and Duke Point; $2 \mathrm{~b}$ has 031, Yakutat Bay, Grant Anchorage, and Cattle Point (see Tables VI and VII).

The assemblages at Montague Harbor and Duke Point (Cluster 2a) are divided almost evenly into quarters. Fixed points, bipoints, awls, and wedges account for about $75 \%$ of each of these two collections. They also have relatively high percentages of flakers. Awls, wedges, and flakers suggest manufacture and repair of important basic equipment, such as clothing, baskets, nets, stakes, posts, bark, and chipped stone implements.

Montague Harbor is a site on the harbor of the same name, on Galiano Island in the Gulf of Georgia (see Table VI). This harbor is so well-protected no waves reach the shore in front of the site. It is approximately 3 miles from the site at Georgeson Bay. Several other shell mounds exist around the protected corners of the harbor. A lagoon is near the site and marshy land and steep rock cliffs lie behind it.

Deer and elk are important in the faunal samples, though shellfish are presumed to account for most of the food resources taken at the site (Mitchell's assessment (1971b); faunal samples were not systematically collected at this site). Salmon was also present in amounts which increased through time. Waterfowl, harbor porpoise, and harbor seal were also among the samples, as were ling cod and rockfish. 
Faunal analysis indicates late fall, early spring, and possible winter occupation.

\section{TABLE VI}

RAW DATA ORGANIZED INTO

INDIVIDUAL TOOL CLASS CLUSTERS - CLUSTER $2 A$

(FIGURES IN PARENTHESES ARE PERCENT OF TOTAL)

$\begin{array}{lll} & \text { MONTH } & \text { DUKE } \\ \text { FIXED PT } & 49(18.7) & 9(14.5) \\ \text { BIPT } & 51(19.5) & 18(29) \\ \text { SHANK } & 0(0) & 1(1.6) \\ \text { HARPOON } & 3(1.2) & 2(3.2) \\ \text { ROD } & 9(3.4) & 1(1.6) \\ \text { VALVE } & 14(5.3) & 5(8.1) \\ \text { AWL } & 53(20.2) & 9(14.5) \\ \text { KNIFE } & 3(1.2) & 0(0) \\ \text { WEDGE } & 54(20.6) & 10(16.1) \\ \text { INCISOR } & & \\ \text { CHISEL } & 3(1.2) & 1(1.6) \\ \text { SHREDDER } & 0(0) & 0(0) \\ \text { FLAKER } & 10(3.8) & 4(6.5) \\ \text { HANDLE } & 8(3.1) & 0(0) \\ \text { PENDANT } & 3(1.2) & 0(0) \\ \text { TABULAR } & 0(0) & 0(0) \\ \text { BEAD } & 1(0.4) & 0(0) \\ \text { CANINE } & 0(0) & 0(0) \\ \text { ORNAM } & 1(0.4) & 2(3.2) \\ \text { TOTAL } & 262 & 62\end{array}$

Large post holes, hearths, and burials were among the features recorded at Montague Harbor. Two of the post molds were considered 1 arge enough to have been members of a substantial plankhouse (Mitche11 1971b, pp. 179, 216). One buried individual showed cranial deformation and another burial included a stemmed, chipped stone point.

Montague Harbor is not a salmon fishing site. Faunal specimens were not systematically collected, so it is difficult to use the faunal sample as a definitive indicator 
of seasonality. The percentage of fixed bone points is low compared to the other sites considered in this study, but the percentage of bipoints is not so low. Bipoints were probably used for catching fish, and perhaps birds. It appears that the occupants were using this site for the lagoon and harbor resources, as well as the deer and elk. They may have been fishing salmon at nearby Active Pass, or someplace farther away. Bone tool analysis suggests that manufacture and repair of implements was of equal importance to procurement activities at this site. While perhaps not a classic "winter village", Montague Harbor may have been a village site used between winter and the salmon season. It is a protected, easily defensible location to fix equipment and catch migratory birds in the 1 agoon and marshes, sea mammals and fish in the harbor, and, of course, shellfish. Evidence of large structures, hearths, and burials suggests that it was, at least, a favored location used over a long period. In any case, it does not appear to be primarily a resource procurement site.

Montague Harbor and Duke Point both sit at the edge of cluster 2 , the "resource modification site" or winter village cluster. In fact, Duke Point was included in one of the resource procurement site clusters in the combined class dendrogram. Like Montague Harbor, nearly $75 \%$ of the Duke Point bone tool assemblage is divided almost evenly between fixed points, bipoints, awls, and wedges. There are some 
differences between the two sites, however. Duke Point has a larger percentage of bipoints and it ties with Skwikwikwab for the highest percentage of flakers among these fifteen sites.

The Duke Point sites face the Nanaimo River estuary and borders a lagoon. This location provides access directly to the resources of the lagoon, the estuary and its adjacent bay, and Northumberland Channel. Nearby, the salmon run on the Nanaimo River. DgRx 5 straddles Canoe Pass, a narrow pass between the ends of Duke Point and Jack Point. Small hearths, floors, and a mass burial were found, but no clear evidence of large structures. Even with the extensive testing done at the site, it is possible that large post molds might have been missed. The faunal analysis was in the preliminary stages when the site report was written and does not offer much information about diet or seasonality. Fish, mainly salmon and herring, were numerous, while waterfowl and deer were also important.

It is apparent that this site has much in common with Montague Harbor. Both border a lagoon and quiet salt water. It is near, but not directly adjacent to a salmon resource. Montague Harbor backs onto a marshy area; Duke Point is near a large estuary. Their bone tool assemblages are quite similar as wel1.

Canoe Pass is an important topographic feature at Duke Point. Nearby resources could be utilized and the bounty 
brought back to the site and unloaded directly from Canoe Pass. The central location and easy access to several resources make Duke Point a very attractive site. Bipoints could be used for catching birds and for fishing. Fixed bone points for fishing and, along with valves, for harpooning the salmon. Awls, wedges, and flakers may have been used for making and repairing nets, stakes, lines and for making temporary sheet-bark structures. Like Montague Harbor, this site was probably not a winter village, but a site centrally located to several resources, used not purely for primary procurement, but for resource modification, as well.

Cluster 2 a sites have in common a diverse bone tool kit of fixed points, bipoints, awls, wedges, and flakers. House structures were identified at Montague Harbor, but not at Duke Point. Faunal analysis at both sites was inconclusive. Environmental and bone tool analysis suggest activities divided fairly equaliy between procurement and modification of resources.

The final sub-cluster, cluster $2 b$, contains 031 and Yakutat Bay, along with Grant Anchorage and Cattle Point (see Table VII). All have low percentages of fixed bone points, low percentages of bipoints (except Grant Anchorage), and very large percentages of awls. Looking at the other tool types, however, there are many individual differences between these four sites. 
031, or Boardwalk, has the highest percentage of awls of any of the fifteen sites. Nearly half of the bone tool assemblage is made up of awls. It also has relatively high percentages of rods and incisor chisels.

\section{TABLE VII}

RAW DATA ORGANIZED INTO

INDIVIDUAL TOOL CLASS CLUSTERS - CLUSTER 2B (FIGURES IN PARENTHESES ARE PERCENT OF TOTAL)

$\begin{array}{lllll} & \text { CATPT } & \text { GRANT } & \text { YAKUB } & \text { 031 } \\ \text { FIXED PT } & \frac{\text { G } 7(15.9)}{9(23.3)} & \frac{16(17.4)}{289}(17.6) \\ \text { BIPT } & 24(8.1) & 64(21.6) & 3(3.3) & 69(4.2) \\ \text { SHANK } & 0(0) & 0(0) & 0(0) & 0(0) \\ \text { HARPOON } & 7(2.4) & 19(6.4) & 10(10.9) & 28(1.7) \\ \text { ROD } & 13(4.4) & 11(3.7) & 1(1.1) & 127(7.7) \\ \text { VALVE } & 3(1) & 1(0.3) & 0(0) & 19(1.2) \\ \text { AWL } & 95(32.1) & 95(32.1) & 36(39.1) & 763(46.4) \\ \text { KNIFE } & 31(10.5) & 7(2.4) & 1(1.1) & 34(2.1) \\ \text { WEDGE } & 45(15.2) & 8(2.7) & 1(1.1) & 87(5.3) \\ \text { INCISOR } & & & & \\ \text { CHISEL } & 3(1) & 6(2) & 12(13) & 142(8.6) \\ \text { SHREDDER } & 0(0) & 0(0) & 0(0) & 2(0.1) \\ \text { FLAKER } & 11(3.7) & 2(0.7) & 0(0) & 11(0.7) \\ \text { HANDLE } & 4(1.4) & 0(0) & 2(2.2) & 9(0.6) \\ \text { PENDANT } & 8(2.7) & 0(0) & 4(4.4) & 23(1.4) \\ \text { TABULAR } & 0(0) & 0(0) & 0(0) & 12(0.7) \\ \text { BEAD } & 2(0.7) & 2(0.7) & 2(2.2) & 6(0.4) \\ \text { CANINE } & 0(0) & 7(2.4) & 3(3.1) & 12(0.7) \\ \text { ORNAM } & \frac{3(0.7)}{296} & \frac{5(1.7)}{293} & \frac{1(1.1)}{92} & 10(0.6) \\ \text { TOTAL } & 296 & 293 & 1643\end{array}$

031 is in Dodge Cove, a 1 arge, shallow protected cove on the east side of Digby Island. This is a large island, with the east coast facing Prince Rupert Harbor and the west coast facing the ocean. Many other 1 arge shell mounds are found in the cove and nearby. Faunal remains indicate a heavy population during fall, winter, and spring, with some light occupation during the summer, as well. Land mammals dominate 
the faunal collection, but sea otters are also important. Sea otter teeth were used to decorate wooden implements, as evidenced archeologically (Daugherty and Friedman 1983; Stewart 1977). The site shows clear evidence of ranking among the many plankhouses (as revealed by quality, size and placement of the houses and their inclusions--see stewart 1977) and in the extensive mortuary material. 031 is certainly a classic winter village.

Looking again at the bone tool assemblage from 031 , it appears that a high percentage of awls and an overall high percentage of modification tools is a good indicator of a permanent or semi-permanent winter village. The relatively high percentage of rods at the site may be due to sea otter and other sea mammal hunting in the kelp beds of the shallow cove. The rather high percentage of incisor chisels, along with the rods and sea otter teeth, suggests a local specialization in fine carving.

Yakutat Bay has an assemblage only slightly different from 031. Like 031, it has low percentages of fixed points and of bipoints and high percentages of awls and incisor chisels. Unlike 031, Yakutat Bay has a low percentage of rods and a high percentage of harpoons. In fact, Yakutat Bay has the highest percentage of harpoons of any of the sites considered here.

The "01d Town" site at Yakutat Bay is clearly a winter village site. The site shows clear evidence of many large 
plankhouses. Its location so far north (at about 59 degrees north latitude) has certain affects on the bone tool assemblage. Active glaciers surround the area, so there are no deer or elk in the environs. Land mammal bone used in tool manufacturing might be limited to animals available locally (bear and beaver) or to ungulate bone acquired by trade. Not surprisingly, then, stone and wood artifacts are more numerous in this setting.

Sea mammals, especially seals, were of greater importance in the diet here than at the other Northwest Coast sites. De Laguna (1972, pp. 376-378) reports that rods were not used around Yakutat Bay. Both sealing and salmon harpooning were done with a harpoon, shaft, and line, but no foreshaft, hence the high percentage of harpoons and low percentage of rods seen in the bone tool assemblage from this site.

Grant Anchorage is a site which changed clusters from the combined class procedure to the individual class procedure. Looking at the assemblage in Table VII shows the reason for this. While it follows the cluster $2 b$ pattern of a high percentage of awls, fixed points and bipoints account for over $40 \%$ of the bone tool assemblage. Grant Anchorage also has a rather $h i g h$ percentage of harpoons and almost no modification tools other than the awls.

Grant Anchorage is in a fairly protected location and has evidence of house structures and planks. Simonsen 
reports that the faunal material represents a "land and littoral" adaptation, probably mainly deer and shellfish. Fresh water is available at the site only in the winter with its heavy rains. Summer occupation would have required traveling some one-half mile for water. This site probably was a winter village, though not a very "wealthy" one. People evidently had to spend much effort during the winter in catching fish with gorges, hooks-and-line, and small harpoons averaging about $9 \mathrm{~cm}$. in total length.

The last of the sites in sub-cluster $2 b$ is Cattle Point. It has low percentages of fixed bone points and bipoints, and a high percentage of awls. It also has a comparatively high percentage of both knives and wedges.

Cattle Point is reportedly in an exposed location on the southern coast of San Juan Island (King 1950; Suttles, pers. comm.). King also reported that an important salmon bank lay just offshore of the site. The season of use has not been established for this site, though deer were important. Features included cairn and interred burials, some with grave goods, clay slab pot-like structures, and long, straight stone alignments, rather like short stone walls.

The site was used aboriginally in spring, for trolling for salmon and fishing for halibut. Camas and acorns may also have been readily available at the site (Suttles, pers. comm.). There are a large number of awls and wedges at Cattle Point. About a quarter of the awls (24) are "abruptly 
pointed awls", or drills. Cattle Point was probably not a winter village site, but it appears that resource modification was an important part of the activities there. Bone wedges may have been used in preparing wood for the fires used in processing camas, acorns, and for drying fish. The reason for the great number of awls is unclear.

The cluster analysis succeeds in giving the three Prince Rupert Harbor sites a context for comparison. Cluster 1 sites of the eighteen tool type cluster analysis are sites where the bone tool assemblages reflect resource procurement activities. 023 and TN1 are both in this cluster. In fact, they are both in the same sub-cluster, 1b. While salmon fishing appears to be the main subsistence activity indicated by the bone tool kits at cluster 1 a sites, and fishing and birding are suggested at cluster 1c sites, cluster 1 b sites show more diversity of activities represented.

Cluster 1 b sites are also resource procurement sites, with sealing and fishing for herring and other fish suggested at Georgeson Bay, sealing and birding at TN1, and herring fishing at 023 .

Cluster 2 site bone tool assemblages reflect more resource modification activity. Cluster 2 a site collections reveal something of a balance between procurement and modification activities, while assemblages from sites in cluster 2b (which contains 031) reflect a much greater emphasis on modification activities. 


\section{CHAPTER $V$}

\section{CONCLUSIONS}

This study began as an attempt to gain some insight into the possible site functions of three Prince Rupert Harbor she11 mound sites (GbTo 31, or "031"; GbTo 23, or "023", and GbTn 1, or "TN1"). It has also been a test of the utility of examining bone tool assemblages from Northwest Coast she 11 mound sites, and of the general utility of clustering procedures with archeological data sets.

The bone and antler tool assemblages from fifteen sites were compared with other information known about the sites to explore underlying regularities which were discovered in the bone tool assemblages. These regularities were discovered by using cluster analysis to order this very complex data set. Twelve of these sites had been previously published, while the three Prince Rupert Harbor were incompletely published or unpublished.

Two cluster analyses were conducted. One used three broad tool categories, the other used eighteen tool classes. The eighteen tool class clusters provided a much more detailed picture of the probable activities reflected by the bone tool assemblages at these sites. One of these clusters (1a) appears to contain salmon camps. The cluster includes 
Shoemaker Bay, Skwikwikwab, and Belcarra Park. Belcarra Park may actually be a winter village site, where much salmon and other fishing was done through the late fall and winter.

Cluster $1 \mathrm{~b}$ of the eighteen tool type tree contain special use procurement sites. Sealing and birding at TN1, herring fishing at 023 , and sealing and herring fishing, probably along with salmon and halibut fishing at Georgeson Bay. Certainly 023 and TN1 are special use procurement sites, while the limited testing done at Georgeson Bay precludes definite knowledge of activities at that site. The eighteen tool type cluster 1c contains the "pure" procurement sites. The assemblages at Hesquiat and at Little Qualicum are completely dominated by fishing, birding, and sea mammal hunting tackle. O'Connor is the only site in this sub-cluster with any manufacturing, repair, or processing equipment.

Cluster 2 in the eighteen tool type procedure includes the sites which generally have more modification tools than procurement tools. Duke Point and Grant Anchorage are the only two members of cluster 2 which have higher percentages of procurement tools than modification tools. Cluster 2 a sites (Montague Harbor and Duke Point) are probably not winter villages, but are procurement sites centrally located near several resources. The bone tool assemblages reveal much manufacture and repair of equipment and probably resource processing as well. These were probably "base 
camps" used for several seasonal activities carried out in close proximity to the site.

The last cluster, cluster $2 b$ of the eighteen tool type tree, represents the "winter village" sites. Yakutat Bay and 031 are certainly classic winter villages. Grant Anchorage is also a winter village, where quite a bit of procurement activity occurred throughout the winter. The abundance of procurement artifacts put this site into the procurement cluster in the combined class dendrogram. Closer examination convinces me that this is a winter village, however.

Cattle Point is an enigma. The lack of faunal data and the lack of clear evidence for structures makes the site difficult to assess in this context. The eighteen tool type dendrogram puts Cattle Point closest to Grant Anchorage, because they both have the lowest percentages of awls in cluster 2. Instead of being a winter village site where procurement activities were undertaken, as at Grant Anchorage, Cattle Point may be a procurement site where many resource modification activities were executed.

These results are encouraging both for the use of bone and antler tool assemblages and for the use of cluster analysis as an aid in looking for patterns among archeological sites. The lack of certainty about the placement of Belcarra Park, Georgeson Bay, and Cattle Point is due to the absence of certain specific elements of supporting information. 
The combined class clustering procedure does not present as clear a picture, of course. It is a good way to reorganize the data, as a check for the clusters formed by a more detailed procedure. It also aids analysis to notice which sites change locations between the combined class and individual tool type dendrograms. Comparing the combined class and eighteen tool type solutions helped define the differences between sub-clusters $2 a$ and $2 b$ in the eighteen tool type tree.

It has been confirmed that it is worthwhile to examine the bone and antler tool as semblages from Northwest Coast shell midden sites as assemblages as well as individual artifacts. While bone tool assemblages used alone are not adequate indicators of site function, they can be useful in clarifying some of the activities undertaken at a shell mound site. This study also confirms the utility of cluster analysis in developing site typologies, when used with careful attention to supporting information and when the stability of the clusters is confirmed by running the procedure on the reorganized data. No definite site typologies were generated in this study, because it would be foolish to base a site typology on the limited information used in this research. It seems likely, however, that the cluster analysis procedure used with all available information would be useful in developing such a site typology (see Thompson 1978). 
In closing, the three objectives of this study (to form hypotheses about site function for GbTo 31, GbTo 23, and GbTn 1 ; to test the utility of using bone tool assemblage analysis as a part of site function assessment; and to test the utility of the cluster analysis procedure with these data) have been met. Hypotheses have been generated regarding site function of the three Prince Rupert Harbor sites--GbTo 31 may be a winter village site, GbTo 23 may be a herring fishing site, and GbTn 1 may be a seal and bird procurement site. Those hypotheses must be tested with further, more detailed research.

Bone tool assemblages were shown to be helpful in site function analysis. While complete site function analysis cannot be based on the bone tool assemblage alone, this kind of analysis can suggest some of the possible activities carried out at a Northwest Coast shell mound site.

The cluster analysis procedure produced stable clusters which revealed underlying regularities in the bone tool assemblages at these sites. Analysis of data other than the bone tool assemblages suggests that these regularities may represent tool kits which may reflect some of the activities practiced at the sites. In other words, the clusters made sense when analyzed with information other than bone tool assemblages.

The information presented here may serve as a data base for future analyses. Bone tool assemblages from other sites 
can be organized into the typology peresented in the Methods chapter and added to the data base presented in Tables II through VII. If these data are then processed with Systat's cluster module (Wilkinson, 1988), some helpful information may result.

Two directions for future research are indicated. First, the hypotheses about the functions of GbTo 31 , GbTo 23, and GbTn 1 should be tested by further, more detailed analysis. Also, it seems possible that a typology of Northwest Coast shell midden sites could be developed using the procedures outlined in this study. 


\section{REFERENCES}

Ackerman, Robert E., Kenneth C. Reid, James D. Gallison, and Mark E. Roe. 1985. Archeology of Heceta Island. Center for Northwest Anthropology, Washington State University, Pullman.

Aldenderfer, Mark S. and Roger K. Blashfield. 1984. Cluster Analysis. Series: Quantitative Applications in the Social Sciences, paper number 44. Sage Publications, Beverly Hills.

Allaire, Louis, George MacDonald and Richard Inglis. 1979.

Gitlaxdzawk: Ethnohistory and Archeology. In Skeena

River Prehistory, edited by Richard Inglis and George MacDonald, pp. 53-166. National Museum of Man Mercury Series, paper number 87 , 0ttawa.

Ames, Kenneth MacIntyre. 1976. The Bone Tool As semblage From the Garden Island Site, Prince Rupert Harbor, British Columbia: An Analysis of As semblage Variation Through Time. Unpublished Ph.D. dissertation, Department of Anthropology, Washington State University, Pullman.

- 1984. Progress Report: Analysis of Artifacts from the Boardwalk Site (GbTo-31): Prince Rupert Harbor, British Columbia. Submitted to the National Museum of Canada, Archeological Survey of Canada, in partial fulfillment of contract \#1630-3M-046.

- 1986. Prehistoric Subsistence Economy in Prince Rupert Harbor, British Columbia. Paper presented at the Canadian Archeological Association Meetings, April 25, Toronto.

Archer, David J. W. 1984. Prince Rupert Harbor Project Heritage Site Evaluation and Impact Assessment. Prepared for the National Museum of Man, permit \#198332 , Ottawa, Ontario.

Archer, David J. W. and Kathryn Bernick. 1983. A Heritage overview Assessment of the Coast Tsimshian Territory in Relation to Proposed Development Projects. Prepared for the Heritage Conservation Branch, Victoria, B.C. 
Barnett, Homer G. 1938. The Coast Salish of Canada. American Anthropologist 40:118-141.

- 1955. The Coast Salish of British Columbia. University of Oregon, Eugene.

Bartz, Albert E. 1981. Basic Statistical Concepts, 2nd ed. Burgess Publication Company, Minneapolis.

Bernick, Kathryn. 1983. A Site Catchment Analysis of the Little Qualicum River Site DiSC 1: A Wet Site on the East Coast of Vancouver Is land, B. C. National Museum of Man Mercury Series, paper number 118, 0ttawa.

Berringer, Patricia Ann. 1982. Northwest Coast Traditional Salmon Fisheries Systems of Resource Utilization. Unpublished Master's thes is, Department of Anthropology and Sociology, University of British Columbia.

Borden, Charles E. 1970. Cultural History of the Fraser Delta Region: An outline. in BC Studies, number 6 and $7: 95-112$.

1975. Origins and Development of Early Northwest Coast Culture to About 3,000 B.C. National Museum of Man Mercury Series, paper number 45, 0ttawa.

1976. Prehistoric Art of the Lower Fraser Region. In Indian Art Traditions of the Northwest Coast, edited by Roy L. Carison, pp. 131-167. Simon Fraser University.

Burley, David V. 1980. Marpole: Anthropological

Reconstruction of a Prehistoric Northwest Coast Culture Iype. Department of Archeology, Simon Fraser University publication number 8. Burnaby, B.C.

Calvert, Gay. 1970. The St. Mungo Cannery Site: A Preliminary Report. B.C. Studies number 6 and 7:54-76.

Calvert, Sheila Gay. 1980. A Cultural Analys is of Faunal Remains from Three Archeological Sites in Hesquiat Harbour, B.C. Unpublished Ph.D. dissertation, Department of Anthropology and Sociology, University of British Columbia.

Carlson, Roy L. 1970. Excavations at Helen Point on Mayne Is 1 and. B.C. Studies number 6 and $7: 113-123$. 
1983a. Prehistory of the Northwest Coast, In Indian Art Traditions of the Northwest Coast edited by Roy L. Carlson, pp. 13-33. Simon Fraser University, Burnaby, B.C.

.1983b. Prehistoric Art of the Central Coast of British Columbia, In Indian Art Traditions of the Northwest Coast edited by Roy L. Carlson, pp. 122-131. Simon Fraser University, Burnaby, B.C.

Chapman, Margaret Winnifred. 1982. Archeological Investigations at the 0 'Connor Site, Port Hardy, In Papers on Central Coast Archeology edited by Philip M. Hobler, pp. 65-140. Simon Fraser University publication number 10 , Burnaby, B.C.

Charlton, Arthur J. 1980. The Belcarra Park Site Simon Fraser University Department of Archeology publication number 9, Burnaby, B.C.

Coupland, Gary Graham. 1985. Prehistoric Change at Kitselas Canyon. Unpublished Ph.D. dissertation, University of British Columbia.

Cowan, I. MCT. and C. J. Guiguet. 1965. The Mammals of British Columbia. British Colunbia Provincial Museum Handbook, number 11, Victoria.

Cybulski, Jerome. n.d. Human Remains from the Boardwalk Site (GbTo 31), Prince Rupert, B. C. Ms. in preparation.

Daugherty, Richard and Janet Friedman. 1983. An Introduction to 0zette Art. In Indian Art Traditions of the Northwest Coast, edited by Roy L. Carlson, pp. 183199. Archeology Press, Simon Fraser University, Burnaby.

de Laguna, Frederica, Francis A. Riddel1, Donald F. McGeein, Kenneth S, Lane, J. Arthur Freed and Carolyn Osborne. 1964. Archeology of the Yakutat Bay Area, Alaska. Smithsonian Institution Bureau of American Ethnology, Bulletin 192, Washington, D.C.

- 1972. Under Mount Saint Elias: The History and CuTture of the Yakutat Tlingit, parts I and III. Smithsonian Contributions to Anthropology, volume 7 . Smithsonian Institute Press, Washington, D.C.

Driver, Harold E. 1969. Indians of North America. 2nd ed., revised. University of Chicago Press, Chicago. 
Drucker, Philip. 1951. The Northern and Central Nootkan Tribes. Bureau of American Ethnology: Bulletin 144. Smithsonian Institute, Washington.

- 1955. Indians of the Northwest Coast. American Museum of Natural History Anthropological Handbook number 10. McGraw-Hill Book Co., New York.

- 1965. Cultures of the North Pacific Coast.

Chandler Publishing Co., San Francisco.

1972. Archeological Survey on the Northern Northwest Coast. Reprinted. Facsimile Reproductions, SJI \#61, The Shorey Bookstore, Seattle Washington. Originally published 1943, Smithsonian Institute Bureau of American Ethnology Bulletin 133, Anthropological

Papers, number 20 .

Fladmark, Knut R. 1974. A Paleoecological Model for Northwest Coast Prehistory. Unpublished Ph.D. dissertation, University of Calgary.

- 1978. A Guide to Basic Archeological Field Procedures. Simon Fraser University Department of Archeology Publication Number 4, Burnaby.

Fladmark, Knut R., Kenneth M. Ames, and Patricia Sutherland. n.d. Prehistory of the Northern British Columbia Coast. Handbook of North American Indians, Volume 9. The Smithsonian Institute Press, Washington, D.C. (in press)

Garfield, Viola E. and Paul S. Wingert. 1950. The Tsimshian Indians and Their Arts. University of Washington Press, Seattle.

Guberlet, Muriel Lewin. 1956. Seaweeds at Ebb Tide. University of Washington Press, Seattle.

Haggarty, James C. and John H.W. Sendey. 1976. Test Excavation at the Georgeson Bay Site, Gulf of Georgia Region, British Columbia. Occasional Papers of the British Columbia Provincial Museum number 19, Victoria, B.C.

Hester, James J. and Sarah M. Nelson (editors). 1978. Studies in Bella Bella Prehistory. Department of Archeology Simon Fraser University publication number 5 , Burnaby, B.C. 
Heusser, Calvin J. 1960. Late-Pleistocene Environments of North Pacific North America. American Geological Society, New York.

Hobler, Philip M. 1970. Archeological Survey and Excavations in the Vicinity of Bella Coola in B.C. Studies, number 6 and $7: 77-94$.

Hoos, Lindsay M. 1975. The Skeena River Estuary: Status of Environmental Knowledge to 1975. Special Estuary Series number 3, Environment Canada.

Hul1, Kimberly. 1980. Faunal Report on the Grassy Bay Site. Ms. submitted to Dr. H. Savage as a class paper, University of Toronto. Copy on file at Portland State University.

Inglis, Richard. n.d. GbTo-31 Final Draft Artifact Analysis, copy of Ms. on file, Portland State University.

Inglis, Richard and George MacDonald, coeditors. 1979. Skeena River Prehistory. National Museum of Man Mercury Series paper number 87 , ottawa.

Kidder, Alfred Vincent. 1932. The Artifacts of Pecos. Phillips Academy, Papers of the Southwest Expedition, number 6 .

King, Arden R. 1974. Cattle Point: A Stratified Site in the Southern Northwest Coast Region. Reprinted. Kraus Reprint Co., Millwood, New York. Originally published 1950, Memoirs of the Society for American Archeology number 7 , Menasha, Wisconsin.

Krause, Aure 1. 1956. The Tlingit Indians. Translated by Erna Gunther. Reprinted. The American Ethnological Society monograph number 26, University of Washington Press, Seattle. Originally Published 1885 .

Kroeber, A. L. 1976. Cultural and Natural Areas of Native North America. Reprinted. Krause Reprint Co., Millwood, New York. Originally published 1939, University of California Publications in American Archeology and Ethnology vol. 38, University of California Press.

Loy, T. and G. R. Powel1. 1977. Archeological Data Recording Guide. British Columbia Provincial Museum Heritage Record number 3 . 
MacDonald, George F. 1968. Field Notes and Catalogue for GbTn-1 British Columbia, Ms. number 6 , volume 22 ,

National Museum of Man, Ottawa. Copy on file at Portland State University.

1976. Prehistoric Art of the Northern Northwest Coast. In Indian Art Traditions of the Northwest Coast. edited by Roy L. Carlson, pp. 99-122. Simon Fraser University, Burnaby, B.C.

MacDonald, George F. and Richard I. Inglis. 1980. An Overview of the North Coast Prehistory Project (1966-1980). In B.C. Studies number 48:37-63.

Mason, 0tis T. 1901. The Technic of Aboriginal American Basketry. In American Anthropologist volume 3:109-128.

1971. Aboriginal American Harpoons: A Study in Ethnic Distribution and Invention. Reprinted. Facsimile Reproductions, \#SJ1-58 The Shorey Bookstore, Seattle Washington. Originally published 1902, an extract from Smithsonian Institute.

Matson, R. G. 1976. The Glenrose Cannery Site. Archeological Survey of Canada, paper number 52. National Museum of Canada, Ottawa.

- 1980. Prehistoric Subsistence Patterns in the Fraser Delta: The Evidence from the Glenrose Cannery Site. In B.C. Studies number 48:64-85.

McMillan, Alan D. and Denis E. St. Claire. 1982. Alberni Prehistory: Archeological and Ethnographic Investigations on Western Vancouver Is land. Theytus Books, Penicton, B.C.

Mitchell, Donald H. 1971a. The Dionisio Point Site and Gulf Is land Culture History. In Syes is volume 4:145-168.

1971b. Archeology of the Gulf of Georgia Area, a Natural Region and its Culture Types. In Syesis, volume 4 supplement 1.

Murray, Rebecca Anne. 1982. Analysis of Artifacts from Four Duke Point Area Sites, Near Nanaimo, B. C.: An Example of Cultural Continuity in the Southern Gulf of Georgia Region. National Museum of Man Mercury Series, paper number 113 , 0ttawa. 
Niblack, Albert P. 1970. The Coast Indians of Southern Alaska and Northern British Columbia. Reprinted. Johnson Reprint Corp., New York. Originally published 1890 , U. S. National Museum Report for 1888, Washington, D.C.

Oberg, Kalervo. 1973. The Social Economy of the Tlingit Indians. University of Washington Press, Seattle.

Onat, Astrida R. Blukis. 1985. Skwikwikwab: A Methodological Study of a Prehistoric Puget Sound Settlement. University Microfilms International \#3592. Ph.D. dissertation 1980, Washington State University, Pullman.

Putnam, Donald F. (editor). 1952. Canadian Regions: A Geography of Canada. Thomas Y. Cromwell Co., New York.

Quayle, D. B. 1960. The Intertidal Bivalves of British Columbia. British Columbia Provincial Museum Handbook number 17, Victoria.

Scammon, Charles M. 1968. The Marine Mammals of the Northwestern Coast of North America. Reprinted. Dover Publications, Inc., New York. Originally published 1874, John H. Carmany and Company, San Francisco.

Shennan, Stephen. 1988. Quantifying Archeology. Edinburgh University Press, Academic Press, Inc., San Diego.

Simonsen, Bjorn 0. 1973. Archeological Investigations in the Hecate Strait-Milbanke Sound Area of British Columbia. Archeological Survey of Canada Mercury Series, paper number 13 , ottawa.

Smith, Harlan I. 1899. Archeological Investigations on the North Pacific Coast in 1899. In American Anthropologist $2(3): 563-567$.

- 1909. Archeological Remains on the Coast of Northern British Columbia and Southern Alaska. In American Anthropologist 11(4):595-600.

Stewart, Francis L. 1975. The Seasonal Availability of Fish Species used by the Coast Tsimshians of Northern British Columbia. In syes is volume $8: 375-388$.

1977. Vertebrate Faunal Remains from the Boardwalk Site (GbTo-31) of Northern British Columbia. Unpublished Ms., copy on file at Portland State University. 
Stewart, Hilary. 1977. Indian Fishing: Early Methods on the Northwest Coast. J. J. Douglas Ltd., Vancouver.

Suttles, Wayne. 1951. The Economic Life of the Coast Salish of Haro and Rosario Straits. Unpublished Ph.D.

dissertation. Department of Anthropology, University of Washington.

1968. Coping with Abundance: Subsistence on the Northwest Coast. In Man the Hunter. edited by Richard B. Lee and Irven DeVore, pp.56-69. Aldine Publishing Co., Chicago.

Thompson, Gai1. 1978. Prehistoric Settlement Changes in the Southern Northwest Coast: A Functional Approach.

University of Washington Department of Archeology Reports in Archeology number 5, Seattle.

Turner, Nancy J. 1975. Food Plants of British Columbia Indians: Coastal Peoples. British Columbia Provincial Museum Handbook number 34 , Victoria.

Wilkinson, Leland. 1988. SYSTAT: The System for Statistics. Systat, Inc., Evanston, Illinois. 


\section{APPENDIX}

PRINCE RUPERT HARBOR ARTIFACT ANALYSIS PROJECT ARTIFACT DESCRIPTION FORMS

ATTRIBUTE LIST FOR BONE TOOLS: MASTER CATEGORIES GENERAL CATEGORY

RAW MATERIAL

TYPE BASE

TIP

OTHER

ANATOMICAL PART

ANATOMICAL ORIENTATION

CONDITION

DORSAL OUTLINE

LONG ITUDINAL OUTL INE

TIP: DORSAL OUTLINE

TIP: LONGITUDINAL OUTLINE

HAFT: DORSAL OUTLINE

HAFT: LONGITUDINAL OUTLINE

BASE : DORSAL OUTLINE

MARROW CAVITY

VENTRAL SURFACE

BARBS

DECORATION

STYLE

TREATMENT

LENGTH

WIDTH

THICKNESS

WE IGHT

RAW MATERIAL:

TERRESTRIAL MAMMAL

SEA MAMMAL

BIRD

F I SH

TEETH :

CAN INE

MOLAR

CLAW

TYPE BASE:

WORKED BASE

ANATOMICAL PART BASE

UNMODIFIED BASE 
TIP :

POINTED

ROUNDED

BEVELED/CHISEL

SQUARE

OTHER :

TUBE

BEAD

PENDENT

ANATOMICAL PART:

UN I DENTIF IED

ULNA

RADIUS

HUMERUS

FEMUR

TI B I A

METAPODIAL

MANDIBLE

MAXILLA

SKULL

PHALANGE

RIB

ANATOMICAL ORIENTATION:

UNKNOWN

PROXIMAL END

DISTAL END

SHAFT

CONDITION :

COMPLETE BONE

UNKNOWN

COMPLETE

LACKS TIP

LACKS ONE END

LACKS POINT

LACKS BOTH ENDS

HAFT AND BASE FRAGMENT

BODY FRAGMENT

DETRITUS

DORSAL OUTLINE :

PARALLEL

TR IANGULAR

OVATE

EXCURVATE

CONCAVO-CONVEX

INCURVATE

I NCURVATE - EXCURVATE

EXCURVATE - INCURVATE

PLANO-CONCAVE

PLANO-CONVEX 
LONGITUDINAL OUTLINE:

PARALLEL

BI POLAR

BICONVEX

OVATE

PLANO-CONVEX

PLANO-CONCAVE

TR I ANGULAR

CONCAVO-CONVEX

I RREGULAR

TIP : DORSAL OUTLINE:

NONE

OVATE

EXCURVATE

PARALLEL

I NCURVATE

CONVEX

CONCAVE

SQUARE

I RREGULAR

TIP : LONGITUDINAL OUTLINE:

NONE

SQUARE OR RECTANGULAR

OVATE

TRI ANGULAR

DORSAL BEVEL

VENTRAL BEVEL

CONVEX

CONCAVE

IRREGULAR

HAFT: DORSAL OUTLINE:

NONE

TAPER

PARALLEL

EXPANDING

INTERNAL

LINE GUARD

LINE HOLE

LINE GROOVE

INCURVATE

STEMME D

IRREGULAR

HAFT: LONGITUDINAL OUTL INE:

NONE

PARALLEL

VENTRAL BEVEL

DORSAL BEVEL

TR I ANGULAR

OVATE

SQUARE

EXPANDING 
BASE : DORSAL OUTLINE :

NONE

RECTANGULAR/SQUARE

TR I ANGULAR

CONVEX

CONCAVE

TRAPEZOIDAL

NOTCHED

I RREGULAR

MARROW CAVITY:

PRESENT

ABSENT

VENTRAL SURFACE:

NONE

CONCAVE

CONVEX

INTERNAL TRIANGULAR

EXTERNAL TRIANGULAR

FLAT

PRISMAT I C

KEELED

BROKEN

BARBS :

NONE

ONE B I LATERAL

TWO OR MORE BILATERAL

ONE UNILATERAL

ONE OR MORE UNILATERAL

DECORAT ION :

NONE

I NC I SED

CARVED

STYLE :

GEOME TR IC ZOOMORPHIC

TREATMENT :

NONE

ENTIRE PIECE POL ISHED

ENTIRE PIECE GROUND

ENTIRE PIECE ABRADED

ENTIRE PIECE FLAKED

ENTIRE PIECE SAWN AND GROUND

DORSAL SURFACE POLISHED

DORSAL SURFACE GROUND

DORSAL SURFACE ABRADED

DORSAL SURFACE FLAKED

DORSAL SURFACE SAWN AND GROUND

VENTRAL SURFACE POLISHED

VENTRAL SURFACE GROUND

VENTRAL SURFACE ABRADED

VENTRAL SURFACE FLAKED

VENTRAL SURFACE SAWN AND GROUND 
TIP ONLY POLISHED

TIP ONLY GROUND

TIP ONLY ABRADED

TIP ONLY FLAKED

TIP ONLY SAWN AND GROUND

\section{LENGTH :}

WIDTH:

THICKNESS :

WE IGHT :

(Metric measurements were taken at the maximum point; measured at the widest point, the thickest point, etc.) 